\section{Pacific Northwest}

National Laboratory

Operated by Battelle for the

U.S. Department of Energy

\title{
Furnace System Testing to Support Lower- Temperature Stabilization of High Chloride Plutonium Oxide Items at the Hanford Plutonium Finishing Plant
}

\author{
A. J. Schmidt \\ M. A. Gerber \\ C. M. Fischer \\ M. R. Elmore
}

April 2003

Prepared for the U.S. Department of Energy under Contract DE-AC06-76RL01830 


\title{
DISCLAIMER
}

This report was prepared as an account of work sponsored by an agency of the United States Government. Neither the United States Government nor any agency thereof, nor Battelle Memorial Institute, nor any of their employees, makes any warranty, express or implied, or assumes any legal liability or responsibility for the accuracy, completeness, or usefulness of any information, apparatus, product, or process disclosed, or represents that its use would not infringe privately owned rights. Reference herein to any specific commercial product, process, or service by trade name, trademark, manufacturer, or otherwise does not necessarily constitute or imply its endorsement, recommendation, or favoring by the United States Government or any agency thereof, or Battelle Memorial Institute. The views and opinions of authors expressed herein do not necessarily state or reflect those of the United States Government or any agency thereof.

\author{
PACIFIC NORTHWEST NATIONAL LABORATORY \\ operated by \\ BATTELLE \\ for the \\ UNITED STATES DEPARTMENT OF ENERGY \\ under Contract DE-AC06-76RL01830
}

This document was printed on recycled paper. 


\title{
Furnace System Testing to Support Lower- Temperature Stabilization of High Chloride Plutonium Oxide Items at the Hanford Plutonium Finishing Plant
}

\author{
A. J. Schmidt \\ M. A. Gerber \\ C. M. Fischer \\ M. R. Elmore
}

April 2003

Prepared for

the U.S. Department of Energy under

Contract DE-AC06-76RL01830 and

the Hanford Nuclear Materials Stabilization Project

Managed for DOE by Fluor Hanford

Pacific Northwest National Laboratory

Richland, Washington 99352 


\section{Executive Summary}

Thermal stabilization of high chloride content plutonium (HCP) items at $750^{\circ} \mathrm{C}$ (without water washing) is being investigated as an alternative method for meeting the intent of DOE STD 3013-2000. Four furnace tests were conducted at $750^{\circ} \mathrm{C}$ to develop material balance and system operability data for supporting the evaluation of lower-temperature thermal stabilization. For each test, a process boat was loaded with simulant $\left(\mathrm{CeO}_{2}\right.$ for $\left.\mathrm{PuO}_{2}\right)$ that represented a 2000-g HCP charge containing $20 \mathrm{wt} \%$ chloride salt (i.e., $1600 \mathrm{~g} \mathrm{PuO}_{2}+400 \mathrm{~g}$ chloride salt). The loaded boat was placed in an RMC-line prototypical furnace system, and the charged furnace was ramped to and held at $750^{\circ} \mathrm{C}$ for $2 \mathrm{hr}$. Air flow through the furnace (room air at $20 \%$ to $40 \%$ relative humidity) was maintained at $1 \mathrm{SCFM}$. Results from the $750^{\circ} \mathrm{C}$ testing were compared with previous results from furnace testing using the same test apparatus but conducted at $1000^{\circ} \mathrm{C}$ with simulant that contained 16 to $20 \mathrm{~g}$ of chloride salt per charge (i.e., simulant represented washed HCP items containing $1 \mathrm{wt} \%$ residual chlorides salts).

The chlorides present in the HCP items pose considerable challenges to stabilization, because volatile chloride salts and decomposition products (e.g., $\mathrm{HCl}$ ) can corrode furnace heating elements and downstream ventilation components. In the cooler zones of the ventilation system, the chloride salts can condense and blind filters or plug the offgas lines. Chloride salt vapor pressures are about 25 times higher at $1000^{\circ} \mathrm{C}$ than at $750^{\circ} \mathrm{C}$, and pyrohydrolysis reactions (reaction of water vapor with chloride salt to produce $\mathrm{HCl}$ ) occur more readily at higher temperature. Therefore, processing at lower temperature potentially can decrease the deleterious effects of the chloride salts.

The following conclusions, derived by comparing results from the $750^{\circ} \mathrm{C} / 20 \mathrm{wt} \%$ salt (unwashed) and $1000^{\circ} \mathrm{C} / 1 \mathrm{wt} \%$ salt (washed) tests, show the operational benefits in the lower-temperature processing without washing:

- Less than $0.9 \mathrm{~g}(0.5 \mathrm{wt} \%)$ of the chloride was volatilized into process equipment by $750^{\circ} \mathrm{C}$ processing of a simulant containing $400 \mathrm{~g}$ of $\mathrm{NaCl}$ and $\mathrm{KCl}$. In contrast, 6.9 to $8.5 \mathrm{~g} \mathrm{(65 \%} \mathrm{to} \mathrm{99 \% )}$ of the chloride was volatilized in $1000^{\circ} \mathrm{C}$ processing of a nominal washed simulant containing 16 to $20 \mathrm{~g}$ of $\mathrm{NaCl}$ and $\mathrm{KCl}$.

- For the same experiments, less $\mathrm{HCl}$ (generated by pyrohydrolysis of the $\mathrm{NaCl} / \mathrm{KCl}$ by the humid purge air) was produced from $400 \mathrm{~g}$ of salt at $750^{\circ} \mathrm{C}$ than from 16 to $20 \mathrm{~g}$ of salt at $1000^{\circ} \mathrm{C}$.

- Less corrosion and salt deposition in offgas lines occurred in the four tests with $20 \mathrm{wt} \%$ chloride salt at $750^{\circ} \mathrm{C}$ (i.e., $1600 \mathrm{~g}$ chloride salt in the four tests) than in a single test with $1 \mathrm{wt} \%$ chloride salt at $1000^{\circ} \mathrm{C}$ (i.e., 16 to $20 \mathrm{~g}$ chloride salt).

- At $750^{\circ} \mathrm{C}$, severe corrosion was confined to the materials in direct contact with the high salt content simulant (boat, metal coupon, and thermocouples); at $1000^{\circ} \mathrm{C}$, severe corrosion was noted in offgas lines as well.

In summary, the low chloride removal and subsequent reduced corrosion to the offgas lines at $750^{\circ} \mathrm{C}$ can largely be attributed to the significantly lower vapor pressure of the chloride salts and the reduced pyrohydrolysis reactions at $750^{\circ} \mathrm{C}$ vs. $1000^{\circ} \mathrm{C}$. 


\section{Summary and Conclusions}

Approximately 1.1 metric tons of impure plutonium oxide scrap items (939 items) that were generated at the Rocky Flats Environmental Technology Site (formerly the Rocky Flats Plant) from pyrochemical operations (electro refining, molten salt extraction, and direct oxide reduction) are being stored at the Hanford Plutonium Finishing Plant (PFP). A significant fraction of these items, referred to as high chloride content plutonium ( $\mathrm{HCP}$ ) oxides, contain $\mathrm{NaCl}, \mathrm{KCl}, \mathrm{MgCl}_{2}$ and/or $\mathrm{CaCl}_{2}$ salts. While these items were previously stabilized at $450^{\circ} \mathrm{C}$, they must now be stabilized in accordance with the U.S. Department of Energy (DOE) Standard, Stabilization, Packaging, and Storage of Plutonium-bearing Materials (DOE-STD-3013-2000), which specifies $950^{\circ} \mathrm{C}$ as the stabilization temperature. The chlorides present in the HCP items pose considerable challenges to stabilization, because volatile chloride salts and decomposition products (e.g., $\mathrm{HCl}$ ) can corrode furnace heating elements and downstream ventilation components. In the cooler zones of the ventilation system, the chloride salts can condense and blind filters or plug the offgas lines. Also, some of the chloride salt impurities are hygroscopic, and those remaining in the calcined solids can make it more difficult to meet the DOE standard for moisture content prior to sealing the stabilized product in 3013 canisters.

The present plan for processing the HCP oxides includes water washing to remove chloride to $<1 \mathrm{wt} \%$ total salt, before thermal stabilization in the RMC line furnaces, to mitigate moisture re-absorption and corrosion problems. Fifty cycles of furnace tests (discussed in a separate report ${ }^{(\mathrm{a})}$ ) were conducted by Pacific Northwest National Laboratory (PNNL), using simulated HCP oxides, to examine system vulnerabilities in the RMC line furnaces under baseline thermal stabilization conditions $\left(2 \mathrm{hr}\right.$ at $\left.1000^{\circ} \mathrm{C}\right)$, and to develop and validate system improvements. These tests showed that, at a $1 \mathrm{wt} \%$ chloride salt loading, most of chloride salt was removed during thermal processing and, consequently, resulted in corrosion to offgas lines and deposition/plugging in cooler downstream offgas lines and offgas filters. However, with process improvements, three to five cycles could be completed during testing before the system had to be shut down for line cleaning and/or filter replacement.

To improve furnace system operability, reduce process and waste disposal costs, and decrease the potential dose to workers involved in the washing process, lower-temperature stabilization of HCP items at $750^{\circ} \mathrm{C}$ (without water washing) is being investigated as an alternative approach for meeting the intent of DOE-STD-3013-2000. A series of four furnace tests were conducted by PNNL to develop material balance and system operability data to support the evaluation of lower-temperature thermal stabilization. Furnace tests were conducted in a system that included a prototype RMC line furnace, a prototype offgas system (offgas lines and a 5- $\mu \mathrm{m}$ filter), a wet scrubber, a chilled condenser, and an offgas blower. For each test, a Hastelloy X process boat was loaded with simulant that represented a 2000 -g HCP charge containing $20 \mathrm{wt} \%$ chloride salt (i.e., $1600 \mathrm{~g} \mathrm{PuO}_{2}+400 \mathrm{~g}$ chloride salt). $\mathrm{CeO}_{2}$ was used as a surrogate for $\mathrm{PuO}_{2}$, and two chloride salt compositions were tested: $\mathrm{NaCl}$ and $\mathrm{KCl}$ added at a 50:50 mole ratio; and $\mathrm{NaCl}, \mathrm{KCl}$, and $\mathrm{MgCl}_{2}$ added at a 45:45:10 mole ratio. Thermocouples and metal coupons were placed in the process boat, and the charged furnace was ramped to and held at $750^{\circ} \mathrm{C}$ for $2 \mathrm{hr}$. Air flow through the furnace (room air at $20 \%$ to $40 \%$ relative humidity) was maintained at 1 SCFM.

(a) Fischer, C. M., M. R. Elmore, A. J. Schmidt, M. A. Gerber, D. S. Muzatko, S. R. Gano, and B. M. Thornton. 2002. Evaluation of PFP Furnace Systems for Thermal Stabilization of Washed High Chloride Plutonium Oxide Items. PNNL-14260, Pacific Northwest National Laboratory, Richland, WA. 
Because the $\mathrm{HCP}$ items stored at PFP were previously thermally processed at or above $450^{\circ} \mathrm{C}$ at the Rocky Flats Plant (many items were thermally processed twice), it is unlikely that significant quantities of $\mathrm{MgCl}_{2}$ are still present. Consequently, the results and observations from the testing conducted with the $\mathrm{MgCl}_{2}$-containing simulant are expected to be more severe than those anticipated from actual thermal stabilization operations, since the simulant was not preconditioned at $450^{\circ} \mathrm{C}$ before the $750^{\circ} \mathrm{C}$ furnace testing.

The furnace testing showed that, at $750^{\circ} \mathrm{C}$, severe corrosion was confined to the materials in direct contact with the high salt content simulant. Test results indicate that the quantity of $\mathrm{HCl}$ generated at $750^{\circ} \mathrm{C}$ from pyrohydrolysis of $\mathrm{NaCl}$ and $\mathrm{KCl}$ in $\mathrm{HCP}$ items (without washing) would be less than that generated from washed $\mathrm{HCP}$ items processed at $1000^{\circ} \mathrm{C}$. Thermal stabilization of $\mathrm{HCP}$ items (without washing) at $750^{\circ} \mathrm{C}$ reduces the technical challenges to the furnace system operations compared with processing washed $\mathrm{HCP}$ items at $1000^{\circ} \mathrm{C}$. However, removal and size-reduction of the calcined material from the boats processed at $750^{\circ} \mathrm{C}$ were found to be labor-intensive. In addition, if HCP items contain appreciable quantities of $\mathrm{MgCl}_{2}$ or other hygroscopic species (e.g., $\mathrm{CaCl}_{2}$ ), actions will need to be taken to minimize exposure of the calcined product to humid air before the material is packaged.

Specific key findings from the furnace testing at $750^{\circ} \mathrm{C}$ are summarized below:

\section{Material Balance}

- Less than $0.5 \mathrm{wt} \%$ of the chloride and less than $0.1 \mathrm{wt} \%$ of the initial simulant mass $(\sim 1.4 \mathrm{~g})$ was removed while processing the $\mathrm{NaCl} / \mathrm{KCl}$ simulant at $750^{\circ} \mathrm{C}$. Of the chloride recovered in the offgas system, about $75 \%$ to $80 \%$ was captured in the wet scrubber and the condenser, both located downstream of a $5-\mu \mathrm{m}$ filter. Approximately $80 \%$ of the chloride in the wet scrubber was derived from $\mathrm{HCl}$ generated from the simulant in the furnace, presumably due to a reaction (pyrohydrolysis) between the alkali chloride salts and the moisture in the furnace sweep gas.

- About $7 \%$ to $13 \%$ of the chloride in the charge was removed while processing the $\mathrm{NaCl} / \mathrm{KCl} / \mathrm{MgCl}_{2}$ simulant at $750^{\circ} \mathrm{C}$. Most of the chloride removal was from the decomposition of $\mathrm{MgCl}_{2}$ in moist air, resulting in the release of $\mathrm{HCl}$. Based on mass balance data, approximately $40 \%$ of the $\mathrm{MgCl}_{2}$ in the feed simulant decomposed to produce $\mathrm{HCl}$, which was removed from the simulant in the boat, and $\mathrm{MgO}$, which was retained in the boat. $\mathrm{MgCl}_{2}$ decomposition continued during furnace cooldown. About one-third of the $\mathrm{HCl}$ in the scrubber was captured while the furnace cooled from $750^{\circ} \mathrm{C}$ to $400^{\circ} \mathrm{C}$. Results from X-ray diffraction (XRD) analyses support the conclusion that some $\mathrm{MgCl}_{2}$ remained in the simulant after processing at $750^{\circ} \mathrm{C}$.

- The effects of the presence of $\mathrm{CaCl}_{2}$ in $\mathrm{HCP}$ oxides were not evaluated as part of the current furnace testing. However, previous work included limited furnace testing with a simulant containing $34.5 \mathrm{wt} \% \mathrm{CaCl}_{2}$ in $\mathrm{CeO}_{2}$ that was calcined at $750^{\circ} \mathrm{C}$ for $2 \mathrm{hr}$ before using the material in washing tests. ${ }^{\text {(a) }}$ Based on chemical analyses and evaluation of the data, it was estimated that between 2 and $6 \mathrm{wt} \%$ of the $\mathrm{CaCl}_{2}$ was pyrohydrolyzed to $\mathrm{CaO}$ and $\mathrm{HCl}$ during the calcining at $750^{\circ} \mathrm{C}$ for $2 \mathrm{hr}$. This finding suggests that the extent of pyrohydrolysis of $\mathrm{CaCl}_{2}$ will be between that of $\mathrm{NaCl} / \mathrm{KCl}$ and $\mathrm{MgCl}_{2}$.

(a) PNNL Letter Report 41291-RPT02, "Evaluation of Solids Rinsing to Treat PFP High Chloride Plutonium Solids," transmitted to P. Sato, Fluor Hanford, by K. L. Silvers, PNNL, December 20, 2002. 
- XRD analysis of the calcined material identified significant quantities of binary sodium/potassium chloride salts.

- In the tests with the $\mathrm{NaCl} / \mathrm{KCl} / \mathrm{MgCl}_{2}$ simulant, significant quantities (5 to $10 \mathrm{~g}$ per test) of hydrated iron and nickel chloride compounds accumulated in the filter housing and on the filter. As there was no evidence of corrosion to the filter housing or filter, the iron chloride compounds most likely originated in the furnace (generated from reactions between simulant, moisture, and boat/metal coupons) and were transported to the filter as vapor. In these tests, very little iron was collected in the wet scrubber.

- The mass of material removed from the boat while processing $20 \mathrm{wt} \% \mathrm{NaCl} / \mathrm{KCl} / \mathrm{MgCl}_{2}$ simulant at $750^{\circ} \mathrm{C}$ was comparable to the mass lost when processing $1 \mathrm{wt} \%$ chloride salt at $1000^{\circ} \mathrm{C}$ under otherwise similar conditions.

\section{Operability}

- During the 2-hr hold time, the temperature of the material in the boat was $50^{\circ} \mathrm{C}$ to $120^{\circ} \mathrm{C}$ higher than the furnace control thermocouple $\left(750^{\circ} \mathrm{C}\right)$. Thus, little incentive or justification exists to control the furnace at a temperature higher than $750^{\circ} \mathrm{C}$.

- While processing $20 \mathrm{wt} \% \mathrm{NaCl} / \mathrm{KCl}$ simulant at $750^{\circ} \mathrm{C}$, corrosion and plugging of offgas lines were minimal, and very little material was collected on the filter. It is estimated that more than 10 batches of such material could be charged to the furnace before shut down is required to clean or replace offgas lines or filters. The extent of corrosion to the Hastelloy $\mathrm{X}$ boat was similar to that experienced while processing $1 \mathrm{wt} \%$ chloride salt at $1000^{\circ} \mathrm{C}$.

- The Hastelloy X boat and the metal coupons (RA602CA and Inconel 690) experienced severe weight loss due to corrosion while processing the $20 \mathrm{wt} \% \mathrm{NaCl} / \mathrm{KCl} / \mathrm{MgCl}_{2}$ simulant at $750^{\circ} \mathrm{C}$. However, the severe corrosive attack was confined to materials in direct contact with the simulant (e.g., boat, thermocouples, and metal coupons). Significant quantities of material (alkali chlorides and hydrated nickel and iron chlorides) did accumulate in the filter element. It is estimated that three to five batches of composition like the $\mathrm{NaCl} / \mathrm{KCl} / \mathrm{MgCl}_{2}$ simulant could be completed before blinding the filter element.

- The cumulative extent of corrosion and salt deposition within the offgas lines during the four tests conducted with $20 \mathrm{wt} \%$ chloride salt at $750^{\circ} \mathrm{C}$ was less than that experienced in a single test with $1 \mathrm{wt} \%$ chloride salt at $1000^{\circ} \mathrm{C}$.

- The high salt loading resulted in the creation of brick-like calcined products. A hammer and a screwdriver were needed to chip the calcined material out of the boat after processing the $\mathrm{NaCl} / \mathrm{KCl}$ simulant. The thermally processed $\mathrm{NaCl} / \mathrm{KCl} / \mathrm{MgCl}_{2}$ simulant was more friable and was removed by inverting the boat, then dropping the boat down several inches onto a hard surface.

- In the test system used, $\mathrm{HCl}$ was largely removed from the offgas stream in the wet scrubber and chilled condenser. Post-test rinsing of offgas lines downstream of the scrubber was performed to remove any $\mathrm{HCl}$. At the PFP, engineering and operational controls will likely be required to minimize the potential for $\mathrm{HCl}$ condensation and subsequent chloride-induced pitting and stress corrosion cracking in the offgas line components. 
- Intake air flow (at ambient humidity in the RMC) should be maintained at the minimum rate to guarantee oxidizing conditions required by the 3013 standard while minimizing water vapor and the resulting pyrohydrolysis reactions that form $\mathrm{HCl}$.

\section{Post-Calcination Moisture Uptake Testing}

Moisture uptake testing was conducted by re-heating (to $250^{\circ} \mathrm{C}$ and $500^{\circ} \mathrm{C}$ ) the feed and calcined samples from the $750^{\circ} \mathrm{C}$ furnace tests and then placing the samples in a controlled humidity chamber $(51 \%$ relative humidity).

- In general, samples from the $\mathrm{NaCl} / \mathrm{KCl}$ simulant only gained about $0.1 \mathrm{wt} \%$ after $24 \mathrm{hr}$ in the controlled humidity chamber. Samples from the $\mathrm{NaCl} / \mathrm{KCl} / \mathrm{MgCl}_{2}$ simulant that were crushed and screened to less than $1 / 4$ in. $(6.35 \mathrm{~mm})$ gained $\sim 0.5 \mathrm{wt} \%$ after 8 to $10 \mathrm{hr}$, while a sample that was screened to less than 16 mesh $(1 \mathrm{~mm})$ gained $\sim 0.5 \mathrm{wt} \%$ after only $2 \mathrm{hr}$. The $\mathrm{CeO}_{2}$ used in the simulants exhibited a very low moisture uptake capacity. Moisture uptake rates for actual HCP items (containing the same chloride salts) would likely be slightly higher given the moisture uptake behavior of $\mathrm{PuO}_{2}$ calcined at $750^{\circ} \mathrm{C}$. 


\section{Acknowledgments}

The authors gratefully acknowledge and appreciate the technical guidance and peer review provided by Cal Delegard. We thank Kurt Silvers for his outstanding project management support. We appreciate the dedicated editorial and document production support provided by Sue Gano and Brenda Thornton.

We thank Todd Hart, who performed inductively coupled plasma (ICP) analyses, and David McCready, who performed X-ray diffraction (XRD) analyses. The ICP and XRD analyses were performed at the William R. Wiley Environmental Molecular Sciences Laboratory (EMSL), a national scientific user facility sponsored by the U.S. Department of Energy's Office of Biological and Environmental Research. EMSL is located at the Pacific Northwest National Laboratory, which is operated for DOE by Battelle. 


\section{Contents}

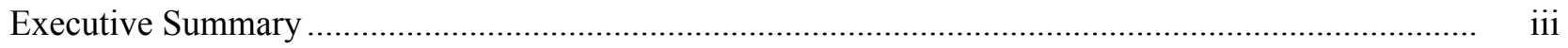

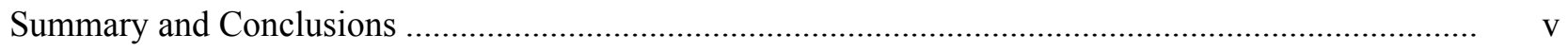

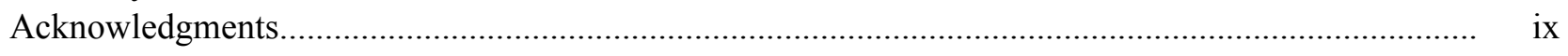

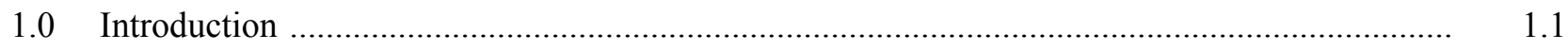

2.0 Test Approach, Equipment, and Methods................................................................................ 2.1

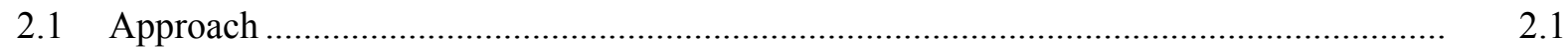

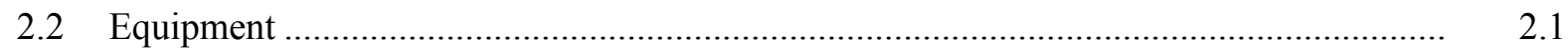

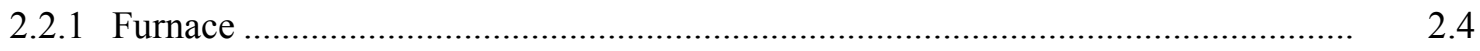

2.2.2 Offgas Line, $3 / 4$ in .................................................................................... 2.4

2.2.3 Filter and Housing ....................................................................................... 2.7

2.2.4 Gas Scrubbing System................................................................................. 2.7

2.2.5 Offgas Blower......................................................................................... 2.10

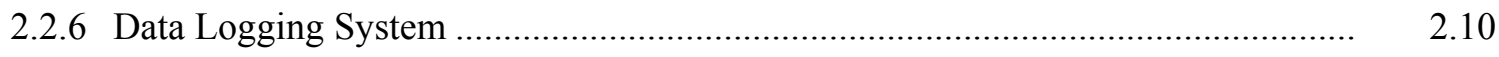

2.3 Methods .................................................................................................... 2.10

2.3.1 Material Balance …………………………………………………………. 2.10

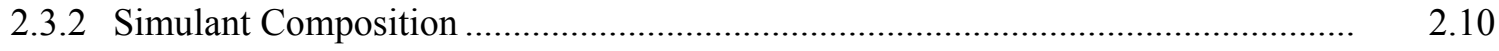

2.3.3 Corrosion Testing ........................................................................................... 2.11

2.3.4 Offgas Line Materials …………………………………………………... 2.12

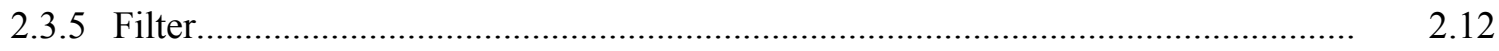

2.3.6 Scrubber and Condenser Operation ................................................................. 2.12

2.3.7 System Leak Check and Offgas Flow Rate Control ............................................. 2.13

2.3.8 Furnace Operation/Process Variables ......................................................................... 2.13

3.0 Results and Discussion............................................................................................ 3.1

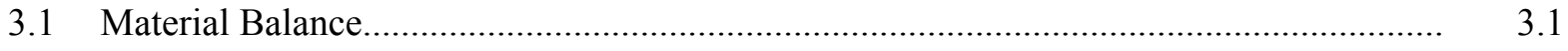

$3.2 \quad$ Scrubber/Condenser Water Analysis.......................................................................... 3.7

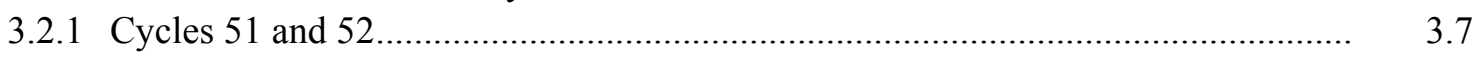

3.2.2 Cycles 53 and 54.................................................................................. 3.8

3.2.3 Cycle 13 Previous Furnace Testing at $1000^{\circ} \mathrm{C}$.................................................. 3.9

3.3 Analysis of Filter and Filter Housing Solids ……………………………………….... 3.11

3.3.1 Filter Solids After Cycle 52 ……………………………………………..... 3.11

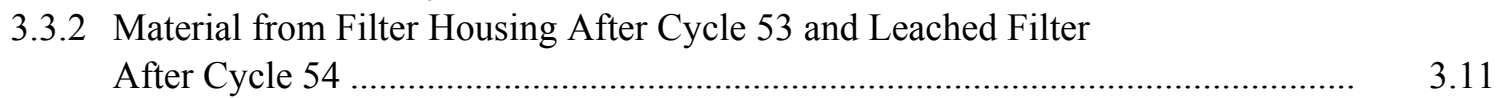

3.4 Results from X-ray Diffraction (XRD) Analysis ………………………………………. 3.15

3.5 Material Performance Testing …………………………………………………...... 3.19

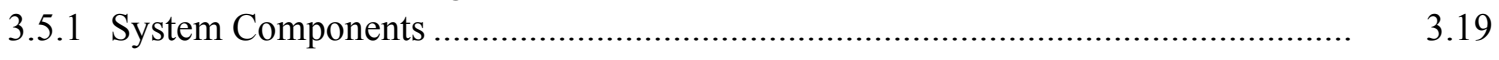

3.5.2 Metal Coupons ………………………………………………………..... 3.20

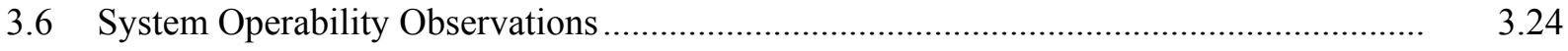

3.6.1 Furnace Temperature Profile ................................................................................. 3.24 
3.6.2 Operability of Furnace System Components .................................................. 3.25

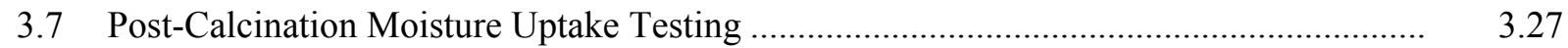

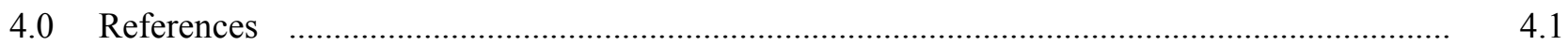

Appendix A - Furnace Operation for HCP Oxide Testing with $750^{\circ} \mathrm{C}$ Hold Temperature .................. A.1

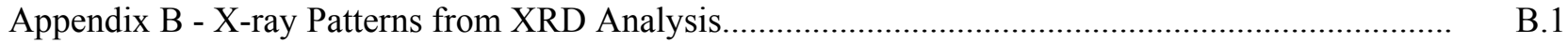

Appendix C - Furnace and Boat Temperature Profiles................................................................. C. 1 


\section{Figures}

2.1 Diagram of Furnace and Offgas System Used for Testing ................................................. 2.2

2.2 Furnace, 3/4-in. Offgas Lines, and Filter Configuration...................................................... 2.3

2.3 Front View of the Furnace Chamber to Show the Arrangement of the Baffle and Support

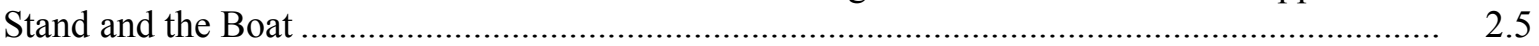

2.4 Internal Offgas Line Inlet and Controller Thermocouple as Installed in the Furnace ................ 2.6

2.5 Bored-out Bulkhead for Supporting 11-in.-long Internal Offgas Lines .................................. 2.6

2.6 Schematic of the Rosedale Filtration System Implementing Pleated Metal Filter Cartridges ..... 2.8

2.7 Rosedale Filter Housing and Element Before Installation ...................................................... 2.9

3.1 Cycle 51, Boat, Simulant, Coupons and Crucible, Before and After Calcination ..................... 3.2

3.2 Deposits Inside Filter Housing After Cycle 53 ................................................................ 3.12

3.3 Condition of 5- $\mu \mathrm{m}$ Rosedale Pleated Metal Filter Element After Cycle 54.............................. 3.14

3.4 Salt Deposits on Outer Shell of 20- $\mu$ m Rosedale Pleated Metal Filter Cartridge After Five

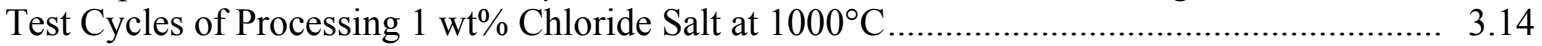

3.5 Crumbled Calcined Material from Cycle 51 ................................................................ 3.17

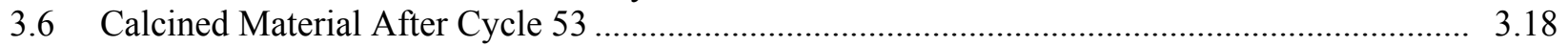

3.7 Initial Condition of RA602CA and Inconel 690 Metal Coupons......................................... 3.21

3.8 RA602CA and Inconel 690 Metal Coupons After Cycles 51 and 52 .................................... 3.22

3.9 Initial Condition of Heat-Treated RA602CA Coupons............................................................ 3.22

3.10 RA602CA and Inconel 690 Metal Coupons After Cycle 54 Coupons Were Partially

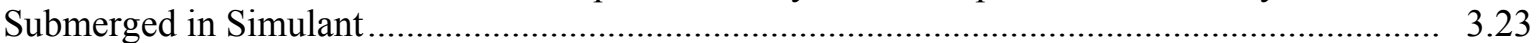

3.11 Minimal Salt Deposits on Inconel 600 Internal Offgas Line After Cycle 54......................... 3.26

3.12 Final Bend on Inconel 600 External Offgas Line Plugged with Salt Deposits After Three

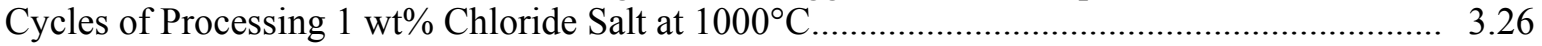

3.13 Percent Weight Gain of $\mathrm{CeO}_{2}$ and Cycle 51 and 52 Samples .............................................. 3.29

3.14 Percent Weight Gain of Cycle 54 Samples .......................................................................... 3.30

3.15 Expanded View of Percent Weight Gain of Cycle 54 Samples .............................................. 3.30

\section{Tables}

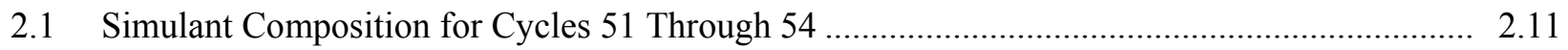

3.1 Mass Balance for Cycles 51 Through 54 ........................................................................... 3.3

3.2 Relative Mole Fractions of $\mathrm{Na}, \mathrm{K}$, and $\mathrm{Mg}$ in Feed and Calcined Simulants ............................ 3.5

3.3 Test Conditions and Chloride Removal ............................................................................ 3.5

3.4 Analyte Concentrations in Scrubber and Condenser Water - Cycles 51 and 52 ...................... 3.7

3.5 Analyte Concentrations in Scrubber and Condenser Water - Cycles 53 and 54 ....................... 3.8

3.6 Analyte Concentrations in Scrubber Water - Cycle 13 .......................................................... 3.10

3.7 Cycle 13 Scrubber Water Chloride Balance ........................................................................... 3.11

3.8 Composition of Filter Solids After Cycle 52 ….............................................................. 3.11

3.9 Composition of Material from Filter Housing After Cycle 53 and Leached Filter After

3.10 Results from X-ray Diffraction Analyses ............................................................................ 3.16

3.11 System Component Weight Data ......................................................................................... 3.19

3.12 Coupon Corrosion Rates During Cycles 51 Through 54 .................................................... 3.24

3.13 Temperature Profile in Boat and Furnace During Cycles 51 Through 54 .............................. 3.24

3.14 Sample Descriptions and Initial Drying Results ............................................................... 3.28 


\subsection{Introduction}

Approximately 1.1 metric tons of impure plutonium oxide scrap items (939 items) that were generated at the Rocky Flats Environmental Technology Site (formerly the Rocky Flats Plant) from pyrochemical operations (electro refining, molten salt extraction, and direct oxide reduction) are being stored at the Hanford Plutonium Finishing Plant (PFP). A significant fraction of these items, referred to as high chloride content plutonium ( $\mathrm{HCP}$ ) oxides, contain $\mathrm{NaCl}, \mathrm{KCl}, \mathrm{MgCl}_{2}$ and/or $\mathrm{CaCl}_{2}$ salts. While these items were previously stabilized at $450^{\circ} \mathrm{C}$, they must now be stabilized in accordance with the U.S. Department of Energy (DOE) Standard, Stabilization, Packaging, and Storage of Plutonium-bearing Materials (DOE-STD-3013-2000), which specifies $950^{\circ} \mathrm{C}$ as the stabilization temperature. The chlorides present in the HCP items pose considerable challenges to stabilization, because volatile chloride salts and decomposition products (e.g., $\mathrm{HCl}$ ) can corrode furnace heating elements and downstream ventilation components. In the cooler zones of the ventilation system, the chloride salts can condense and blind filters or plug the offgas lines. Also, some of the chloride salt impurities are hygroscopic, and those remaining in the calcined solids can make it more difficult to meet the DOE standard for moisture content prior to sealing the stabilized product in 3013 canisters.

In an evaluation conducted for PFP, Pacific Northwest National Laboratory (PNNL) recommended converting PFP's existing solutions precipitation equipment to a washing process as the preferred option for treating the HCP oxides [PNNL Letter Report 43925-L01, "Technical Evaluation of Candidate Alternatives for Treating High Chloride Content Plutonium Oxides at the Plutonium Finishing Plant" transmitted to D. R. Speer, Fluor Hanford (FH), by K. L. Silvers, PNNL, April 15, 2002]. A target salt concentration of $\sim 0.25 \mathrm{wt} \%$ or less was proposed to ensure that most washed batches of HCP solids would meet the $0.5 \mathrm{wt} \%$ moisture limit established by the DOE 3013 Standard, and to minimize corrosion to furnace components during thermal stabilization. The evaluation also recommended that the existing RMC line furnaces ${ }^{(a)}$ be used to thermally stabilize the washed material. The PFP SPE line furnaces ${ }^{(b)}$ were not recommended for processing the HCP items, because the wall in those furnaces (constructed of alloy RA602CA) constitutes a primary glovebox containment barrier, and undue corrosion and penetration of this wall would cause Pu particles to escape into the manned process areas.

PFP contracted with PNNL to conduct testing to validate the use of existing furnaces in the RMC for thermal stabilization of the washed material. A high-temperature furnace (same make and model as used at the RMC line at PFP) and the associated offgas system were set up at PNNL to identify system vulnerabilities and to investigate alternative materials and operating conditions that would reduce any corrosion and plugging of furnace and offgas components. The key areas of interest for this testing were the furnace heating elements; the offgas line located inside the furnace; the offgas line between the furnace and the filter/knockout pot; the filter/knockout pot itself; the sample boat; and corrosion coupons (to evaluate alternative materials of construction). The testing was conducted by charging the furnace with $\mathrm{CeO}_{2}, \mathrm{a} \mathrm{PuO}_{2}$ surrogate, that had been impregnated with a mixture of chloride salts (selected to

(a) The RMC line furnaces are muffle furnaces that draw ambient air through the furnace chamber during operation. The relative humidity (RH) of the ambient air at PFP and in the RMC line can reach $60 \%$ or more, because swamp coolers are used to cool the building. This humidity can affect the calcination chemistry in the furnace and can create a challenge to meeting the $0.5 \mathrm{wt} \%$ moisture limit when samples are cooled and removed from the oven. Thermal stabilization operations are administratively controlled so as not to occur when $\mathrm{RH}$ is greater than $60 \%$.

(b) The humidity is controlled in the SPE line furnaces and glovebox, with the moisture content maintained to less than 300 to $600 \mathrm{ppm}$. 
represent the expected residual chloride salt level in washed $\mathrm{HCP}$ items) and heated to $1000^{\circ} \mathrm{C}$ in the furnace in accordance with the temperature ramp rates and hold times used at PFP. [Note: a hold temperature of $1000^{\circ} \mathrm{C}$ is used in the $\mathrm{RMC}$ line furnaces at PFP to guarantee the material in the boat is stabilized at $950^{\circ} \mathrm{C}$ in accordance with the DOE 3013 Standard]. The simulant charge loaded into the furnace for each cycle represented 1600 or $2000 \mathrm{~g}$ of $\mathrm{PuO}_{2}$ containing $1 \mathrm{wt} \%$ chloride salt. The chloride salt mixture consisted of $45 \mathrm{~mole} \% \mathrm{NaCl}, 45 \mathrm{~mole} \% \mathrm{KCl}$, and $10 \mathrm{~mole} \% \mathrm{MgCl}_{2}$. Fifty furnace test cycles (Cycles 1 through 50) were completed with the furnace test system (Fischer et al. 2002). These tests showed that, at a $1 \mathrm{wt} \%$ chloride salt loading, the chloride salts evaporate (and decompose) from the process boats and corrode offgas lines, and deposit and plug the cooler downstream offgas lines and the offgas particulate filters. However, with process improvements, three to five cycles could be completed during the testing before the system had to be shut down for line cleaning and/or filter replacement.

The work discussed here is a follow-on to the previous tests at $1000^{\circ} \mathrm{C}(\mathrm{Cycles} 1$ through 50$)$ to evaluate thermal stabilization of the HCP items at $750^{\circ} \mathrm{C}$. Chloride salt vapor pressures are about 25 times higher at $1000^{\circ} \mathrm{C}$ than at $750^{\circ} \mathrm{C}$, and pyrohydrolysis reactions (reaction of water vapor with chloride salt to produce $\mathrm{HCl}$ ) occur more readily at higher temperature. Therefore, processing at lower temperature potentially can decrease the deleterious effects of the chloride salts. Reducing the thermal stabilization temperature is expected to provide a number of benefits:

- improve the efficiency of PFP operations

- decrease (perhaps eliminate) the complex and dose-intensive washing operation

- decrease liquid waste generation from the water wash steps

- avoid radiological worker exposure associated with equipment repair due to corrosion

- free personnel resources for other stabilization and Decontamination and Decommissioning activities.

As part of the lower-temperature thermal stabilization investigation, a case is being developed to demonstrate that technical equivalency with DOE 3013 Standard goals can be maintained at the lower temperature. This report was prepared for the Plateau Transition Division of DOE's Richland Operations Office, and was funded under a technical assistance program through the DOE-Environmental Management (EM) Office of Science and Technology.

A series of four furnace tests (Cycles 51 through 54) were conducted by PNNL to develop material balance and system operability data in support of the technical equivalency demonstration for thermal stabilization of $\mathrm{HCP}$ items at $750^{\circ} \mathrm{C}$. Section 2.0 of this report describes the test approach, as well as the furnace system equipment, test materials, and testing methods. To the extent practicable, the furnace system equipment used in the testing at $1000^{\circ} \mathrm{C}$ was also used in the $750^{\circ} \mathrm{C}$ testing.

Section 3.0 presents the test results and includes detailed material balances, analytical results, equipment and materials performance data, component operability information, and moisture uptake testing performed on HCP simulant material calcined at $750^{\circ} \mathrm{C}$. Where appropriate, comparisons with results of prior furnace testing at $1000^{\circ} \mathrm{C}$ were made.

Appendix A summarizes the procedures used to conduct each furnace test cycle. Appendix B provides $\mathrm{X}$-ray patterns from X-ray diffraction (XRD) analyses performed on select samples. Plots of the furnace and boat temperature profiles from each test are provided in Appendix C. 


\subsection{Test Approach, Equipment, and Methods}

This section describes the test approach, as well as the furnace system equipment (furnace, offgas lines, filter, scrubber, and condenser), test materials, and testing methods.

\subsection{Approach}

A series of furnace tests were conducted to develop material balance and system operability data for supporting the evaluation of lower-temperature thermal stabilization. Four furnace tests (Cycles 51 through 54) were conducted in a system that included a prototype RMC line furnace, a prototype offgas system (offgas lines and a 5- $\mu \mathrm{m}$ filter), a wet scrubber, a chilled condenser, and an offgas blower. For each test, a Hastelloy X process boat was loaded with simulant that represented a 2000 -g HCP charge containing $20 \mathrm{wt} \%$ chloride salt (i.e., $1600 \mathrm{~g} \mathrm{PuO}_{2}+400 \mathrm{~g}$ chloride salt). $\mathrm{CeO}_{2}$ was used as a surrogate for $\mathrm{PuO}_{2}$. ${ }^{\text {(a) }}$ Two chloride salt compositions were tested: 1) $\mathrm{NaCl}$ and $\mathrm{KCl}$ added at a 50:50 mole ratio and 2) $\mathrm{NaCl}, \mathrm{KCl}$, and $\mathrm{MgCl}_{2}$ added at a 45:45:10 mole ratio. A crucible loaded with simulant, thermocouples, and metal coupons was placed in the process boat, and the charged furnace was ramped to and held at $750^{\circ} \mathrm{C}$ for $2 \mathrm{hr}$. Air flow through the furnace (room air at $20 \%$ to $40 \%$ relative humidity) was maintained at $1 \mathrm{SCFM}$. The temperature ramp profile and air flow rates were prototypical of, but did not constrain, expected PFP operations.

The furnace performance was evaluated by monitoring the current and voltage to the heating elements and monitoring the temperature in the furnace chamber. The offgas system performance was monitored by measuring temperature, pressure drop, and flow rate. Between cycles, furnace and offgas system components and metal coupons were examined, photographed, and weighed to obtain material balance information and to evaluate corrosion. Samples were collected from the feed simulant, calcined simulant, filter, filter housing, scrubber, and condenser, and were subjected to chemical analyses to determine the distribution of chloride and chloride salt throughout the test system.

\subsection{Equipment}

The test stand used for the furnace system evaluation is illustrated in Figure 2.1, which shows the major components of the test system (prototype RMC line furnace, prototype offgas system, wet scrubber, chilled condenser, and offgas blower). Figure 2.2 is a detailed schematic of the furnace, 3/4-in. offgas lines, and the particulate filter. Figures 2.1 and 2.2 also show the location of thermocouples, pressure gauges, and the offgas flow meter.

(a) The suitability of $\mathrm{CeO}_{2}$ as a surrogate for $\mathrm{PuO}_{2}$ in chloride salt melts was examined. While $\mathrm{CeO}_{2}$ is a more powerful oxidant than $\mathrm{PuO}_{2}$ and thus potentially able to oxidize chloride to chlorine gas, the potential reactions of $\mathrm{CeO}_{2}$ with melts of $\mathrm{NaCl}, \mathrm{KCl}$, and eutectic $\mathrm{NaCl} / \mathrm{KCl}$ to form chlorine

$$
\mathrm{CeO}_{2}+\mathrm{Cl}^{-} \rightarrow \mathrm{Ce}^{3+}+2 \mathrm{O}^{2-}+\mathrm{Cl}
$$

have been considered in past studies to determine the solubility of $\mathrm{CeO}_{2}\left(\right.$ and $\left.\mathrm{Ce}_{2} \mathrm{O}_{3}\right)$ in these media from just above their respective melting points (i.e., $800^{\circ} \mathrm{C}, 770^{\circ} \mathrm{C}$, and $700^{\circ} \mathrm{C}$ ) to $1000^{\circ} \mathrm{C}$ (Reinhard and Naumann 1968). However, in their carefully designed studies, the researchers observed no evidence of free chlorine. Their investigations instead showed that, at given temperature, cerium concentrations in the melts with $\mathrm{CeO}_{2}$ (e.g., for the $\mathrm{NaCl} / \mathrm{KCl}$ eutectic at $700-1000^{\circ} \mathrm{C}, 6.5 \times 10^{-6}-5.4 \times 10^{-5}$ moles $/ \mathrm{kg}$ salt) were $\sim 5$ to 10 times higher than those found for similar experiments using $\mathrm{Ce}_{2} \mathrm{O}_{3}\left(5.7 \times 10^{-7}-1.2 \times 10^{-5} \mathrm{moles} / \mathrm{kg}\right.$ salt $)$. The higher solubility of $\mathrm{CeO}_{2}$ was attributed to the higher charge density of the $\mathrm{Ce}^{4+}$ ion compared with the $\mathrm{Ce}^{3+}$ ion. No solid phases in the tests, other than $\mathrm{CeO}_{2}$, were observed. 


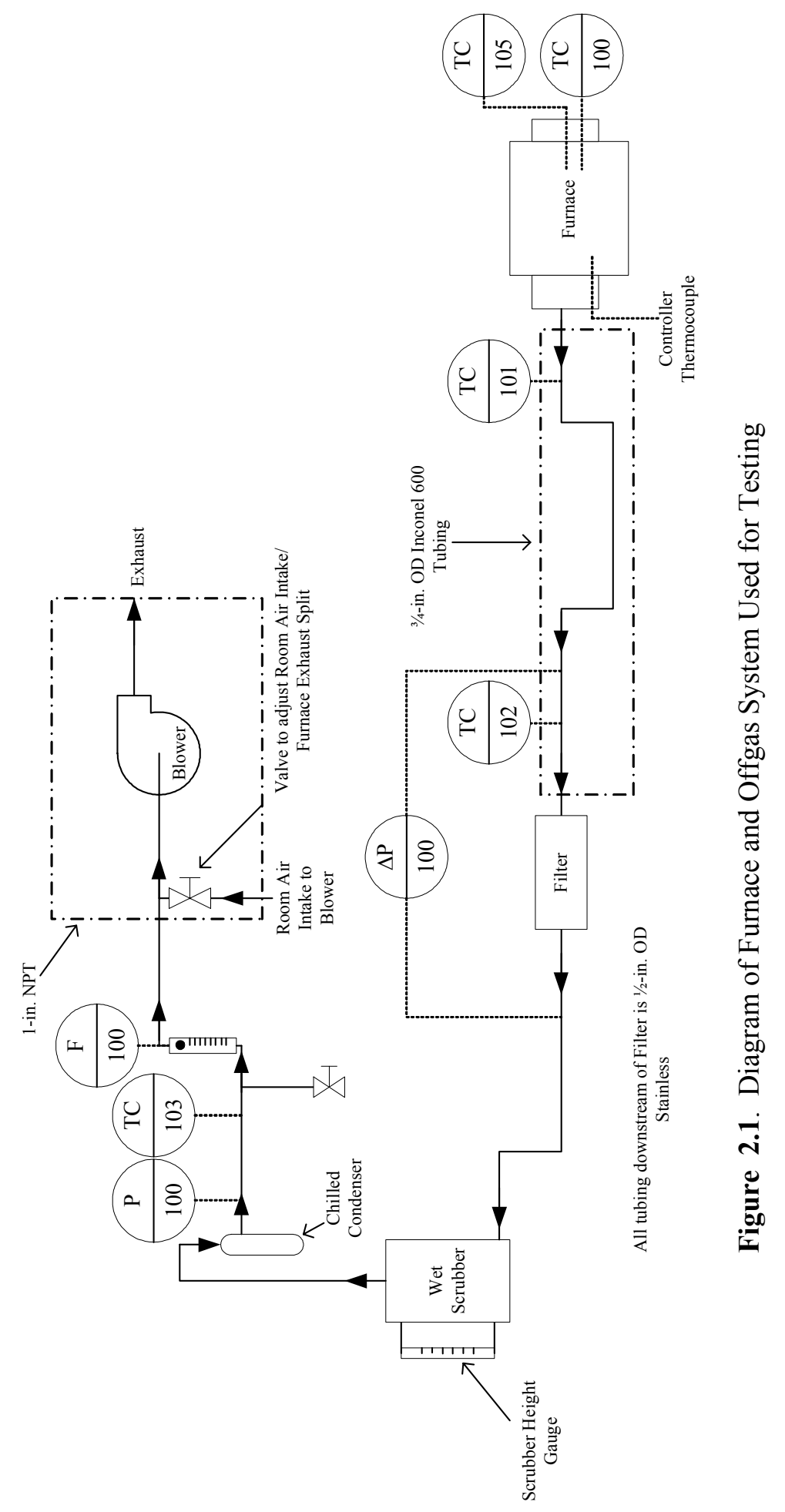




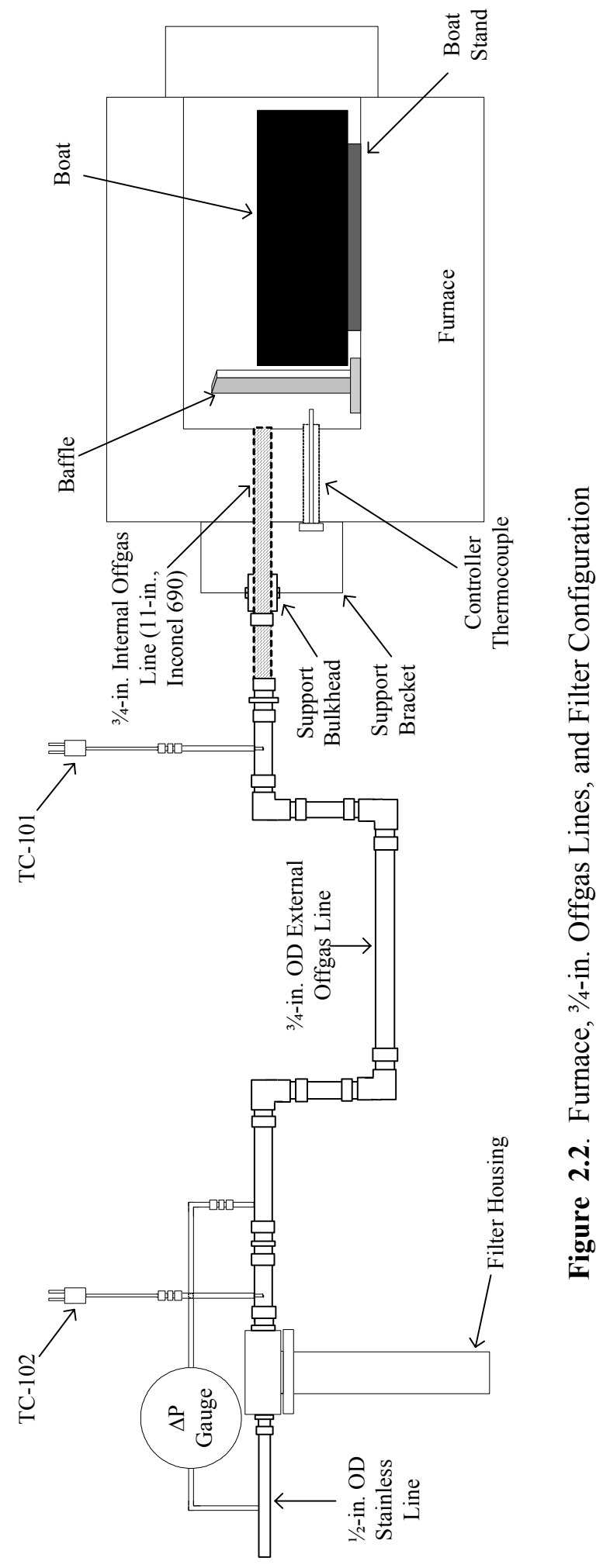




\subsubsection{Furnace}

A Thermolyne Model FA-1630-1 muffle furnace was used, (i.e., the same furnace model that is used in the PFP RMC line for materials stabilization). Four 240 VAC, 17.0 A heating elements, wired in series, lined the top, bottom, and side walls of the furnace. Actual dimensions of the furnace chamber with heating elements installed were 5.5 in. wide x 5 in. high x 13 in. deep (total chamber volume: 357.5 in. $^{3}$ ). Maximum short-term and continuous operating temperatures recommended by the manufacturer were $1177^{\circ} \mathrm{C}$ and $1066^{\circ} \mathrm{C}$, respectively. A ceramic stand was placed inside the furnace directly on the bottom heating element to support a Hastelloy $\mathrm{X}$ boat, which was $11 \mathrm{in.} \mathrm{long} \mathrm{x} 5 \mathrm{in}$. wide $\mathrm{x} 2.5 \mathrm{in}$. high. The boat was used to hold simulant, a crucible, and the metal coupons used for corrosion evaluation. A baffle constructed of Haynes HR-160 alloy was located at the back wall of the furnace chamber behind the boat, directly in front of where the gases exited the furnace. The arrangement of the baffle, support stand, and sample boat in the furnace is shown in Figure 2.3.

The furnace temperature was controlled with a proportional-integral-derivative (PID) controller coupled with a silicon-controlled rectifier (SCR). The PID controller was a Eurotherm Model 818 process controller capable of running temperature ramp/dwell sequences. The SCR was a Control Concepts, Inc., Model 1039 power controller rated for $30 \mathrm{~A}$ at $208 \mathrm{VAC}$ (P/N 1039-V-208V-30A-F30-4/20MA). Both the process controller and the SCR were properly fused and grounded. Temperature input to the controller was provided by an Omega 1/4-in.-outer diameter (OD), 7-in.-long type K thermocouple (I-600 sheathed, P/N TJ48-CAIN-14U-7-SB-OSTW-M). Figures 2.2 and 2.4 show the location of the controller thermocouple. Two Omega 1/8-in.-OD, 24-in.-long type K thermocouples (I-600 sheathed, $\mathrm{P} / \mathrm{N}$ KQIN-18U-24) were inserted through the front of the furnace between the door and the furnace housing with the tips submerged into the simulant. A Kaowool pad (i.e., refractory ceramic fiber) was inserted between the furnace housing and the furnace door to provide a reasonable seal around the thermocouples.

The available power supply in the lab was $208 \mathrm{VAC}$, not $240 \mathrm{VAC}$ as rated by the heating elements. This did not appear to affect the furnace element operation.

\subsubsection{Offgas Line, $3 / 4$ in.}

The 3/4-in.-OD offgas line between the furnace and the filter housing was divided into an internal and external section, as shown in Figure 2.2. The internal offgas line began inside the furnace with the inlet mounted flush with the back wall of the furnace (Figure 2.4). It extended out the back wall of the furnace and was supported by a bracket/bulkhead assembly mounted to the back of the furnace. The internal offgas line used in these tests was an 11-in.-long section of 1/2-in. Schedule 80 Inconel 690 pipe (0.840-in. OD), turned to 3/4-in.-OD, 6-in.-long, 0.102-in. wall thickness (i.e., same material and configuration being installed at PFP in the RMC line for processing the HCP items). The internal offgas line was inserted completely through a bored-out bulkhead fitting (Figure 2.5).

The external offgas line was connected directly to the internal offgas line with a union. The 38-in.-long external line was 3/4-in.-OD Inconel 600 tubing, 0.028-in. wall thickness. There were four 90-degree bends to better represent the current system used by PFP (Figure 2.2). The four bends used 90-degree elbows constructed of 316L stainless steel. Two Omega 1/8-in.-OD, 12-in.-long type K thermocouples (I-600 sheathed, P/N KQIN-18U-12) were inserted into the offgas line. See Figure 2.2 for locations. 

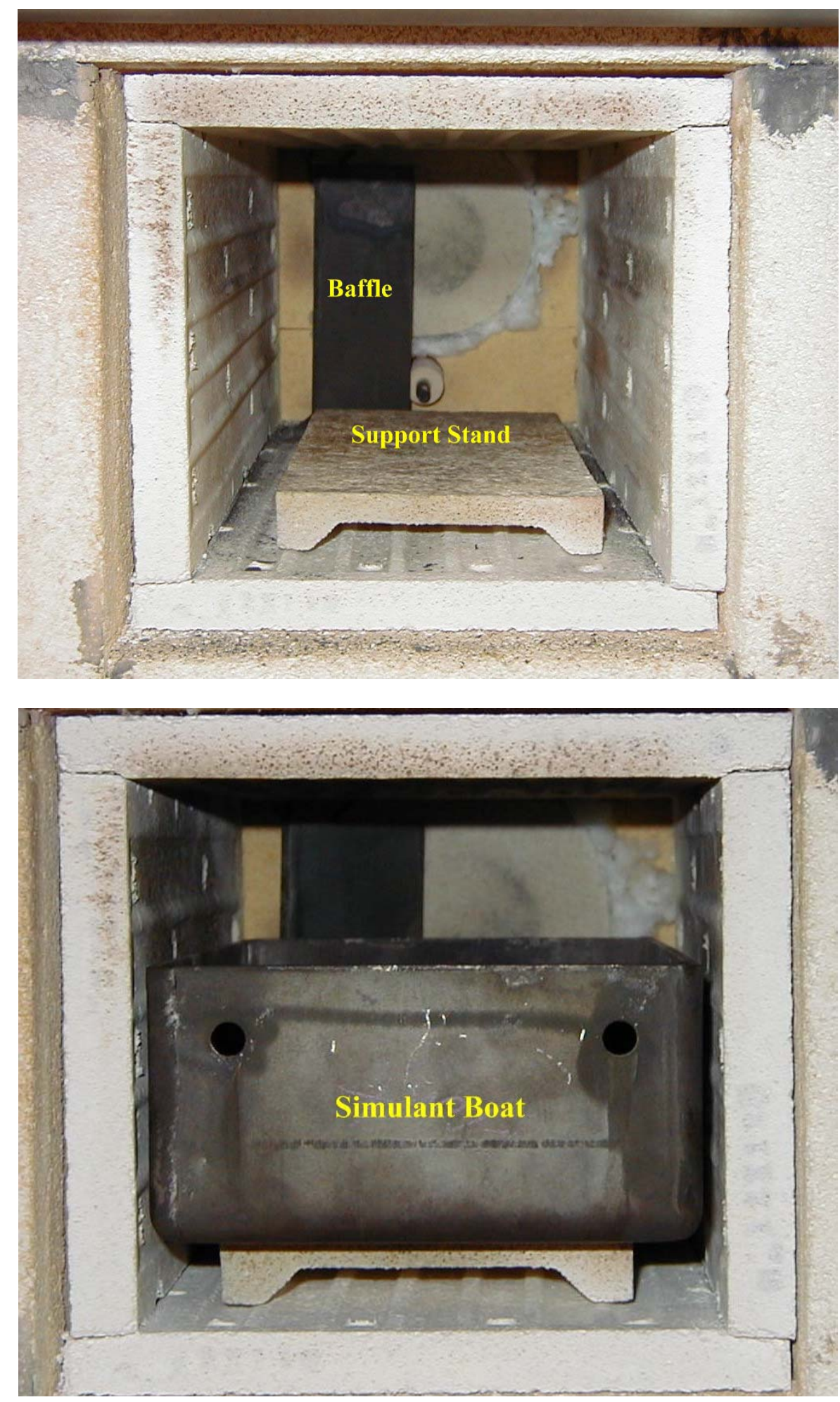

Figure 2.3. Front View of the Furnace Chamber to Show the Arrangement of the Baffle and Support Stand (above) and the Boat (below). Note that the furnace chamber was just wide enough for the boat to fit. 


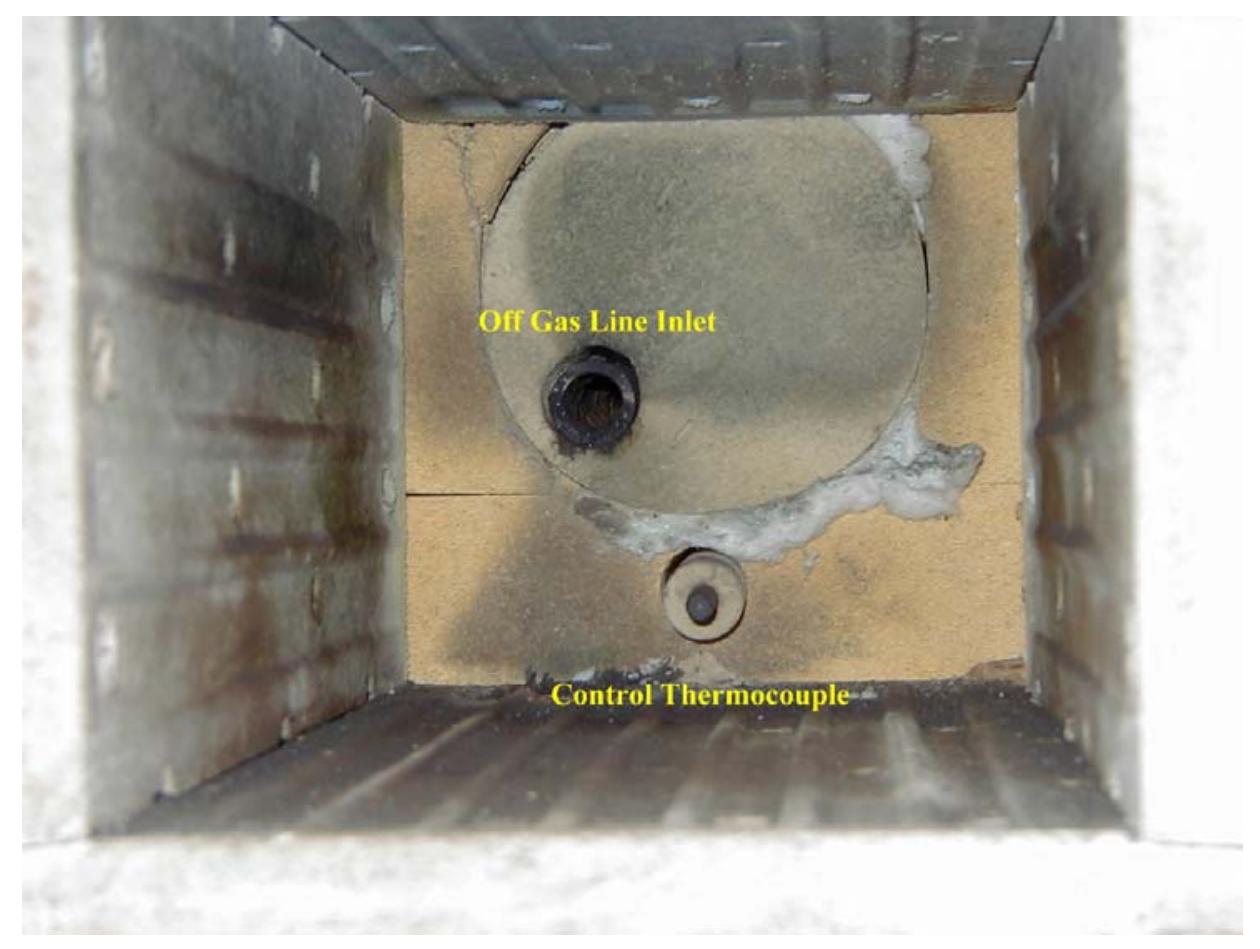

Figure 2.4. Internal Offgas Line Inlet and Controller Thermocouple as Installed in the Furnace (baffle removed)

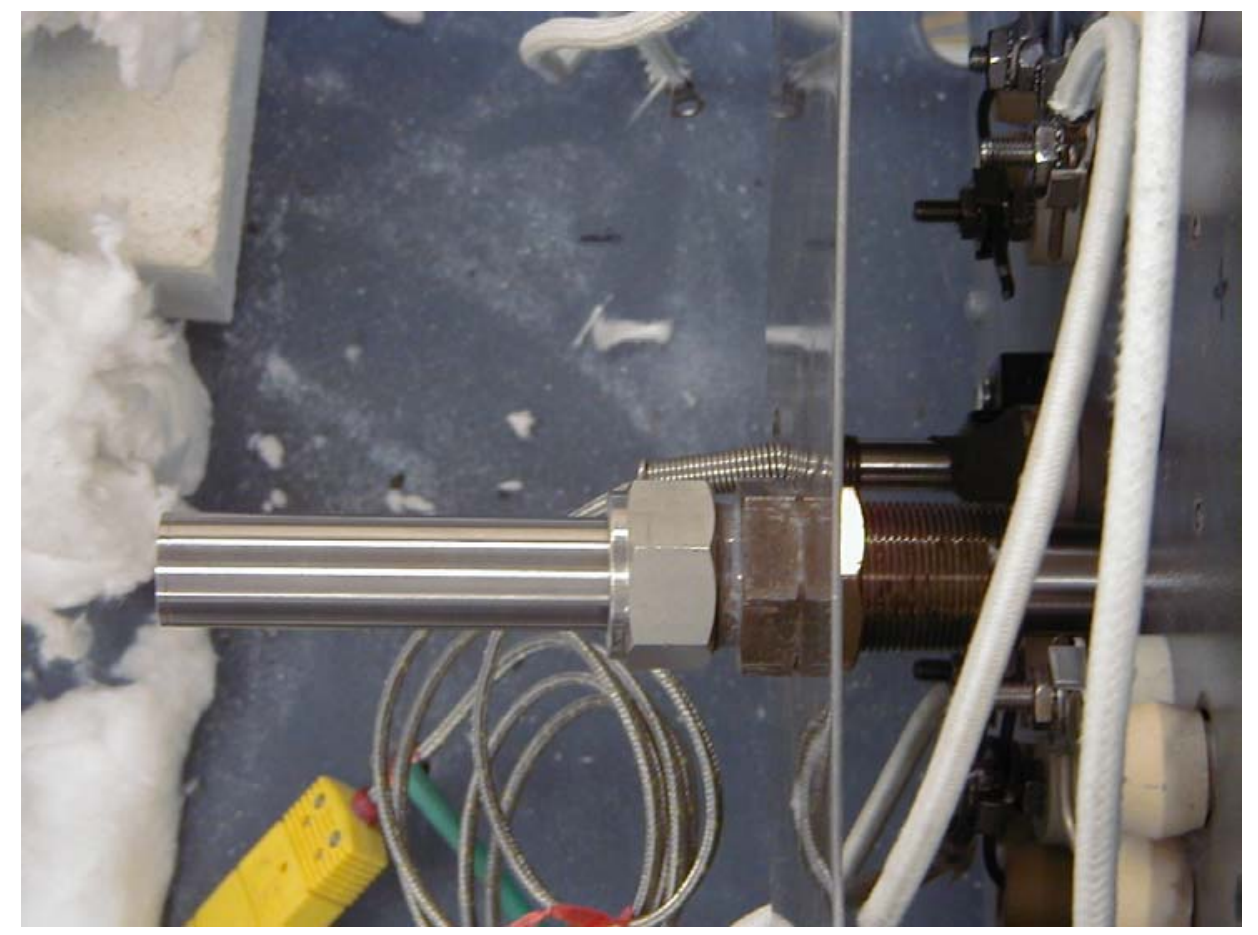

Figure 2.5. Bored-out Bulkhead for Supporting 11-in.-long Internal Offgas Lines 


\subsubsection{Filter and Housing}

A filter was connected downstream of the external offgas line for particulate removal (Figure 2.1). The filtration system evaluated is comparable to the system being installed at PFP downstream of the RMC line furnaces.

The installation schematics and photos of the filter and housing used in the testing are shown in Figures 2.6 and 2.7. Both the filter element and the filter housing were supplied by Rosedale Products of California, Inc. (Coarsegold, California), and are described below.

\section{Housing:}

- $\quad$ P/N 4-1-20-3/4P-2-50-S-(SP)-N-NPT (NPT = National Pipe Taper Thread), Model 4, 304 stainless steel, 4.5-in. OD (body), 10-in. OD (flange), 30-in. overall length (including flange thickness and outlet port), $91 \mathrm{lb}$ shipping weight.

- $\quad$ Holds one 20-in.-long filter cartridge.

- $593^{\circ} \mathrm{C}$ maximum temperature (at $50 \mathrm{psi} \max$ ).

Filter:

- 5- $\mu \mathrm{m}(\mathrm{P} / \mathrm{N} 20-5-\mathrm{P}-\mathrm{S}-1 \mathrm{NPTF}-\mathrm{SP}), 304$ stainless steel pleated element.

- 20-in.-long, 2.6-in. OD (per cartridge).

- $593^{\circ} \mathrm{C}$ maximum temperature.

- Filter surface area (for one cartridge): $500 \mathrm{in.}^{2}$

The pressure drop across the filter was measured with a Dwyer 0-15 in.- $\mathrm{H}_{2} \mathrm{O} 2000$ Series Magnehelic $\Delta \mathrm{P}$ gauge (Model 2015).

\subsubsection{Gas Scrubbing System}

The layout of the scrubbing system is shown in Figure 2.1. All tubing downstream of the filter housing was 1/2-in.-OD 304 stainless steel. The offgas exiting the filter was directed through a sparge tube located inside a 12 5/8-in.-OD x 24 5/8-in.-high 304 stainless steel tank. The sparge tube was $\sim 10$ in. long with ten 1/8-in. holes and submerged in 8 to 11 in. of water. A sight glass was installed onto the side of the tank to monitor water level.

The offgas exited the top of the scrubber tank and entered a 1-L condenser pot (304L stainless steel) to remove water from the saturated offgas stream. The condenser pot was submerged in a 5-gal bucket filled with ice and water during each run. After passing through the condenser, the offgas was re-heated to $\sim 30^{\circ} \mathrm{C}$ with a heat tape, and then passed through a Dwyer Model RMA-10-TMV 0-200 SCFH flow meter. (the offgas was heated to raise its temperature to the flow meter calibration temperature and to prevent condensation within the flow meter.) An Omega 1/8-in.-OD, 12-in.-long type $\mathrm{K}$ thermocouple (I-600 sheathed, P/N KQIN-18U-12) and a Dwyer 0-30 in. $-\mathrm{H}_{2} \mathrm{O} 2000$ Series Magnehelic $\Delta \mathrm{P}$ gauge (Model 2030) were located on the 1/2-in. stainless steel line between the heat tape and the flow meter. Directly below the flow meter was a section of $1 / 2$-in.-OD tubing that served as a drop leg to catch any remaining condensate. 


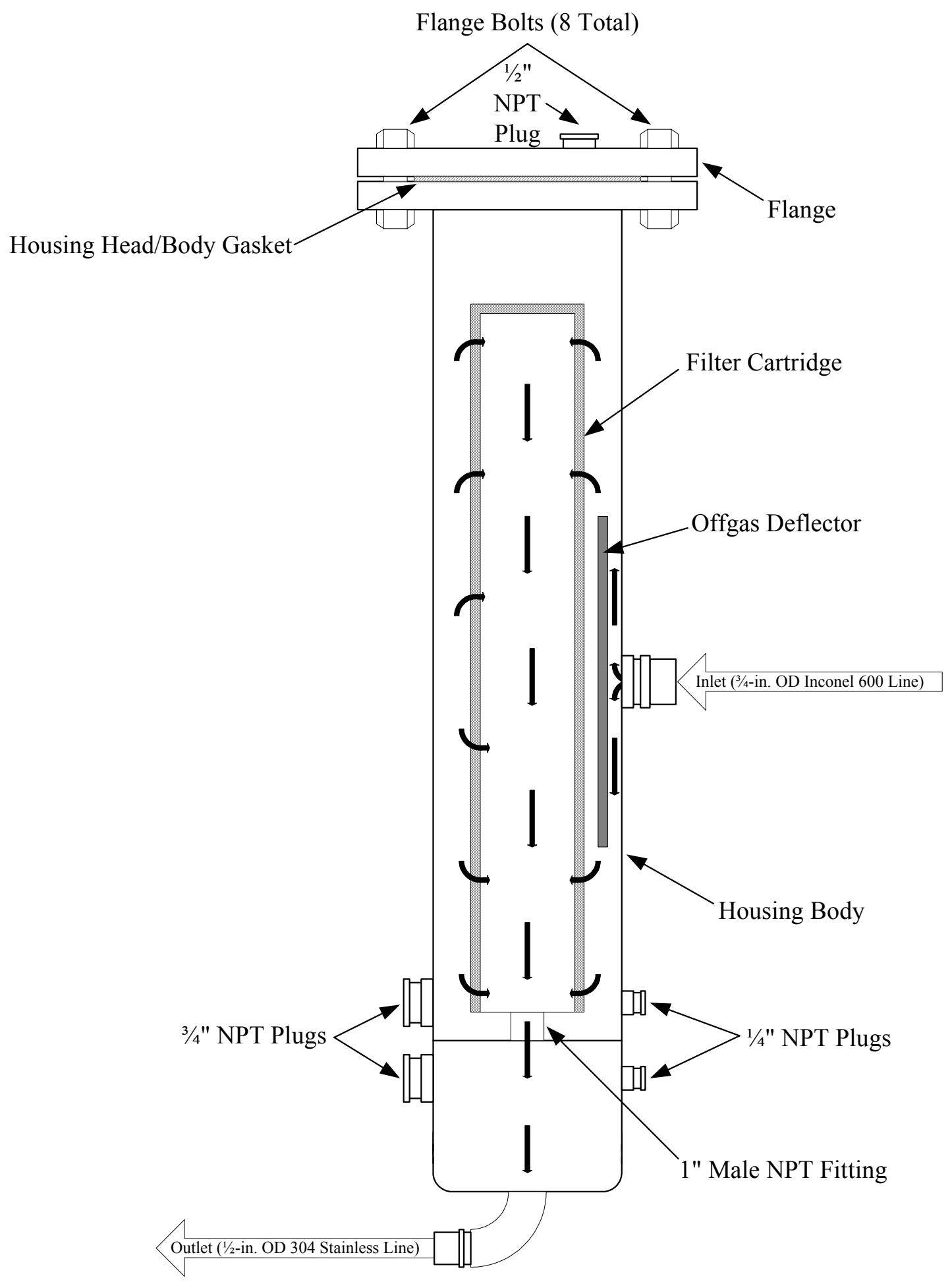

Figure 2.6. Schematic of the Rosedale Filtration System Implementing Pleated Metal Filter Cartridges 


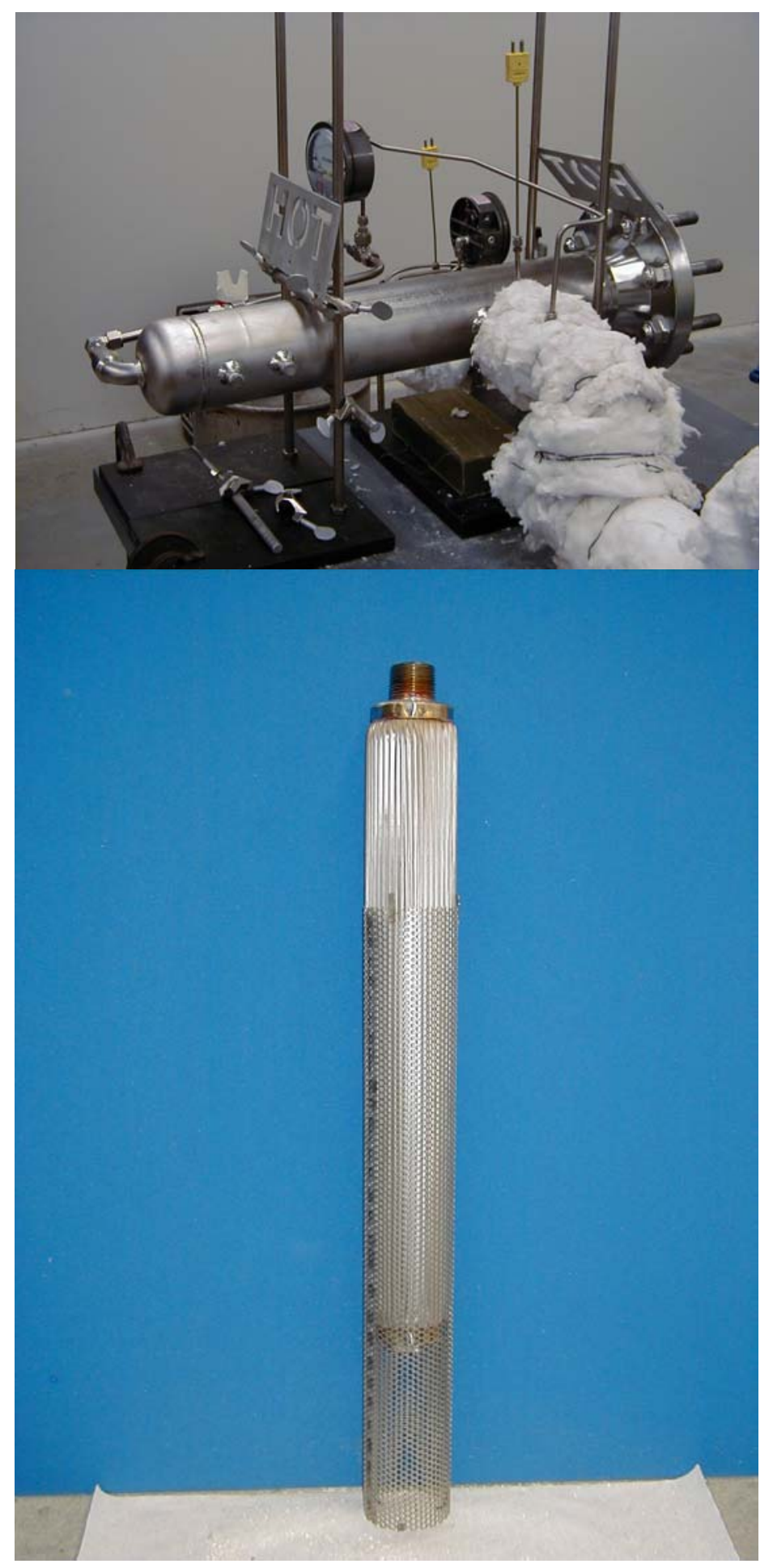

Figure 2.7. Rosedale Filter Housing and Element Before Installation. Housing outer diameter was $4.5 \mathrm{in}$. and shipped at $91 \mathrm{lb}$. Filter element was 2.6-in. OD and 20-in. long, and is shown with the pleat protector partially removed. 


\subsubsection{Offgas Blower}

The offgas flow was provided by a Model R2103 Gast Regenair blower (P/N LTD139) capable of $42 \mathrm{CFM}$ free air flow $\left(20^{\circ} \mathrm{C}, 14.7\right.$ PSIA $)$ or 35 in. $-\mathrm{H}_{2} \mathrm{O}$ vacuum. Due to the high capacity of the blower, the majority of air flow was pulled directly from the room, while the target 1.0 SCFM offgas flow from the furnace was maintained with a valve located on the room air inlet (Figure 2.1). The room air inlet and the blower exhaust lines were 1-in. NPT.

\subsubsection{Data Logging System}

An Iotech Personal Daq/56 data logging system was used to record process data. Temperatures were recorded from the process controller thermocouple and others located in the simulant boat, Inconel 600 offgas line, and just upstream of the flow meter. Furnace voltage and current data from the SCR were also recorded. At the end of a furnace test cycle, the data were downloaded to an Excel worksheet for analysis.

\subsection{Methods}

The methods used to conduct the furnace system testing and to obtain test data are described.

\subsubsection{Material Balance}

Material balances were performed for each run (cycle) conducted at $750^{\circ} \mathrm{C}$. The mass of simulant in the boat was measured before and after each test. A mass balance was also performed around the offgas lines, the filter element, and the scrubber and condensate water. As expected, a direct material balance around the boat was found to be inconclusive. Corrosion products from the boat and metal coupons commingled with the calcined material in the boat. Consequently, to develop a more precise material balance, a cylindrical crucible was placed in the center of the boat in each run and was filled with simulant to the same level as that in the boat. The walls of the crucible thus minimized the amount of corrosion products mixing with the contents.

Chemical analyses [inductively coupled plasma spectrometry (ICP) for cations and ion selective electrode (ISE) for chloride] were performed on simulant (fresh and calcined), on material collected on the filter, and on scrubber and condensate water samples. Select samples were also analyzed via XRD for phase identification.

\subsubsection{Simulant Composition}

Each furnace charge was formulated to represent a 2000 -g charge containing $20 \mathrm{wt} \%$ chloride salt (i.e., $1600 \mathrm{~g} \mathrm{PuO}_{2}+400 \mathrm{~g}$ chloride salt). On a mole basis, $1016 \mathrm{~g} \mathrm{CeO}_{2}$ is equivalent to $1600 \mathrm{~g} \mathrm{PuO}_{2}$; therefore, $\sim 1016 \mathrm{~g} \mathrm{CeO}_{2}$ was used in each test. Two compositions of chloride salt were tested. The first composition was a mixture of $\mathrm{NaCl}$ and $\mathrm{KCl}$ at mole ratio of 50:50. The second composition was a 
mixture of $\mathrm{NaCl}, \mathrm{KCl}$, and $\mathrm{MgCl}_{2}{ }^{(\mathrm{a})}$ at a mole ratio of 45:45:10, respectively. The $\mathrm{MgCl}_{2}$ used for preparing the simulant was hydrated $\left(\mathrm{MgCl}_{2} \cdot 6 \mathrm{H}_{2} \mathrm{O}\right)$. For both simulant compositions, the chloride salt was first ground to a fine powder then mixed with $\mathrm{CeO}_{2}$ using a large mortar and pestle. To carefully control the simulant composition heterogeneity, simulant charges were prepared individually for each test. Fresh reagent-grade chemicals $\left(\mathrm{CeO}_{2}, \mathrm{NaCl}, \mathrm{KCl}, \mathrm{MgCl}_{2} \cdot 6 \mathrm{H}_{2} \mathrm{O}\right)$ were used in all tests The simulant compositions are given in Table 2.1.

Table 2.1. Simulant Composition for Cycles 51 Through 54

\begin{tabular}{|c|c|c|c|c|c|}
\hline \multirow[b]{2}{*}{ Component } & \multirow{2}{*}{$\begin{array}{c}\text { Molecular } \\
\text { Weight }\end{array}$} & \multirow{2}{*}{$\begin{array}{c}\text { Mole } \\
\text { Fraction }\end{array}$} & \multirow{2}{*}{$\begin{array}{c}\text { Weight } \\
\text { Fraction }\end{array}$} & \multicolumn{2}{|c|}{ Mass Per Charge, $g$} \\
\hline & & & & Target & Simulant \\
\hline \multicolumn{6}{|c|}{ Plutonium Oxide Fraction } \\
\hline $\mathrm{PuO}_{2}$ & 271.1 & 1.0 & 1.0 & 1600 & -- \\
\hline $\mathrm{CeO}_{2}$ & 172 & 1.0 & 1.0 & -- & 1016.02 \\
\hline \multicolumn{6}{|c|}{ Chloride Salt Fraction } \\
\hline \multicolumn{6}{|c|}{ Simulant 1 - Cycles 51 and 52} \\
\hline $\mathrm{NaCl}$ (Used in simulant) & 58.44 & 0.50 & 0.439 & 175.76 & 175.76 \\
\hline $\mathrm{KCl}$ (Used in simulant) & 74.56 & 0.50 & 0.561 & 224.24 & 224.24 \\
\hline \multicolumn{6}{|c|}{ Simulant 2 - Cycles 53 and 54} \\
\hline $\mathrm{NaCl}$ (Used in simulant) & 58.44 & 0.45 & 0.379 & 151.64 & 151.64 \\
\hline $\mathrm{KCl}$ (Used in simulant) & 74.56 & 0.45 & 0.483 & 193.46 & 193.46 \\
\hline $\mathrm{MgCl}_{2}$ (Target) & 95.220 & 0.1 & 0.137 & 54.90 & \\
\hline $\begin{array}{l}\mathrm{MgCl}_{2} \cdot 6 \mathrm{H}_{2} \mathrm{O} \text { (Used for } \\
\mathrm{MgCl}_{2} \text { in simulant) }\end{array}$ & 203.31 & \multicolumn{3}{|c|}{--} & 117.23 \\
\hline
\end{tabular}

\subsubsection{Corrosion Testing}

A combination of standard coupon corrosion tests and in-service testing of system components (e.g., heaters, boats, baffles, offgas tubing, etc.) was used for the corrosion and materials evaluations. Coupon corrosion tests utilized rectangular specimens of candidate metal alloy materials. Initial specimens were prepared from standard mill-finish plate. Tests consisted of initially characterizing all specimens, followed by exposing the specimens to furnace/offgas conditions during the test cycles. The corrosion specimens were first characterized by carefully weighing (nearest $0.0001 \mathrm{~g}$ ) and measuring dimensions (nearest 0.01 in.). Coupons were placed in the boats ( $\sim 1 / 2$ submerged in the simulant). After exposure, the coupons were evaluated for corrosion types and penetration rates. The evaluation included observations of the condition "as is" upon removal and cleaning to remove corrosion products, followed by weighing and visual examination. Similar post-test examinations were conducted for the furnace and offgas system components to evaluate the nature and degree of chloride attack during operation.

(a) Because the HCP items stored at PFP were previously thermally processed at or above $450^{\circ} \mathrm{C}$ at the Rocky Flats Plant (many items were thermally processed twice), it is unlikely that significant quantities of $\mathrm{MgCl}_{2}$ are still present. Additionally, the Rocky Flats Plant processes from which the HCP items were generated should have resulted in the decomposition of most of the $\mathrm{MgCl}_{2}$. Consequently, the results and observations from the testing conducted with the $\mathrm{MgCl}_{2}$-containing simulant are expected to be more severe than those anticipated from actual thermal stabilization operations, since the simulant was not preconditioned at $450^{\circ} \mathrm{C}$ before the $750^{\circ} \mathrm{C}$ furnace testing. 
The following alloys were used for corrosion specimen materials during Cycles 51 through 54:

- RA602CA (mill-finish plate)

- Inconel 690 (mill-finish plate)

RA602CA, the material of construction of the retort system in the SPE furnaces, was evaluated to explore the potential processing of HCP items in the SPE line. Inconel 690 coupons were also examined. Inconel 690 coupons were previously evaluated in the furnace system testing conducted with $1 \mathrm{wt} \%$ chloride salt at $1000^{\circ} \mathrm{C}$ (Fischer et al. 2002). The results from both sets of data were compared.

Cycle 54 included two additional RA602CA coupons, provided by PFP. These coupons, which included several welds, were heat treated at $1000^{\circ} \mathrm{C}$ for $3.75 \mathrm{hr}$ to form a protective oxide coating.

\subsubsection{Offgas Line Materials}

A new internal offgas line was initially cleaned, photographed, weighed, and measured in the same manner as the corrosion specimens. The external offgas line was thoroughly cleaned and weighed before Cycle 51. To duplicate the RMC line furnace system operations, the offgas line between the furnace and filter housing was insulated with Kaowool. At PFP, the offgas line is insulated to minimize the heat load to the glovebox.

\subsubsection{Filter}

A new filter element was installed before Cycle 51. In previous testing, filter elements were considered blinded and replaced after the pressure drop increased significantly (approximately 6 to 8 in.- $\mathrm{H}_{2} \mathrm{O}$ ). In the current testing, the same filter element was used for all test cycles. The performance of the filter was tracked during the testing by monitoring pressure drop. After each test, the filter element and housing were inspected and photographed as appropriate. The filter element was also removed and weighed to quantify particulate collection.

\subsubsection{Scrubber and Condenser Operation}

The offgas scrubber and condenser were cleaned, and a measured quantity of deionized water was added to the scrubber before the first test. Scrubber water samples were collected before and after each test. After Cycle 51 (simulant containing $\mathrm{NaCl}$ and $\mathrm{KCl}$ ), a relatively small drop in the $\mathrm{pH}$ of the scrubber water was measured. Therefore, the scrubber water was not replaced for Cycle 52. However, the scrubber water was replaced before Cycles 53 and 54 (simulant containing $\mathrm{NaCl}, \mathrm{KCl}$, and $\mathrm{MgCl}_{2}$ ). Also, during Cycles 53 and 54, scrubber water samples were collected immediately after completion of the 2-hr hold time at $750^{\circ} \mathrm{C}$ and after the furnace had cooled to about $400^{\circ} \mathrm{C}$. Offgas flow was continued during the cooldown from $750^{\circ} \mathrm{C}$ to $400^{\circ} \mathrm{C}$.

Condensate was removed from the condenser after each test. The condensate $(\sim 130 \mathrm{ml})$ was combined with the liquid captured in the drop leg $(0.3$ to $2 \mathrm{ml})$ to form the "condensate sample" for each test. After each test, the condenser, the flow meter, and the offgas lines between the scrubber and the blower were cleaned. 


\subsubsection{System Leak Check and Offgas Flow Rate Control}

Before each test cycle, a leak check was performed on the offgas system. First, a high flow rate was established through the offgas system. Next, the internal offgas line was blocked, and the flow meter and pressure gauge were observed. If a high vacuum and zero flow through the flow meter were observed, the offgas system was considered leak tight.

The offgas flow rate was maintained at 1 SCFM during furnace operations. In general, once the flow rate was set at the beginning of the run, no adjustments were necessary. The temperature of the offgas passing through the rotameter was maintained at approximately $30^{\circ} \mathrm{C}$ with heat tape located between the chilled condenser and the flow meter. Before any testing, the calibration of the flow meter was verified at $30^{\circ} \mathrm{C}$.

\subsubsection{Furnace Operation/Process Variables}

For each cycle, a $\mathrm{CeO}_{2}$ simulant containing chloride salt was loaded into a boat; the boat was placed in the furnace chamber; and the furnace was heated in accordance with the proposed low-temperature PFP thermal stabilization protocol:

1. Room temperature to $500^{\circ} \mathrm{C} @ 300^{\circ} \mathrm{C} / \mathrm{hr}$

2. $500^{\circ} \mathrm{C}$ to $700^{\circ} \mathrm{C} @ 200^{\circ} \mathrm{C} / \mathrm{hr}$

3.700 $70^{\circ} \mathrm{C}$ to $750^{\circ} \mathrm{C} @ 125^{\circ} \mathrm{C} / \mathrm{hr}$

4. Hold at $750^{\circ} \mathrm{C}$ for $2 \mathrm{hr}$, then shut off furnace power and cool.

The furnace operation procedure and a list of the measured process variables with sampling frequencies can be found in Appendix A. 


\subsection{Results and Discussion}

A total of four furnace cycles (Cycles 51 through 54) were completed, with approximately $400 \mathrm{~g}$ of chloride salt (i.e., $20 \mathrm{wt} \%$ chloride salt) charged to the furnace in each cycle. For Cycles 51 through 54, the temperature was ramped to and held at $750^{\circ} \mathrm{C}$ for $2 \mathrm{hr}$. Cycles 51 and 52 were conducted with $\mathrm{NaCl}$ and $\mathrm{KCl}$ added at a 50:50 mole ratio. Cycles 53 and 54 were conducted with $\mathrm{NaCl}, \mathrm{KCl}$, and $\mathrm{MgCl}_{2}$ added at a 45:45:10 mole ratio. The results of the four test cycles are discussed here. In previous furnace testing (Fischer et al. 2002), Cycles 2 through 7 and 9 were conducted with $16 \mathrm{~g}$ of chloride salt $(\mathrm{NaCl}$, $\mathrm{KCl}$, and $\mathrm{MgCl}_{2}$ added at a 45:45:10 ratio); and Cycles 34 through 36 were conducted with $20 \mathrm{~g}$ of chloride salt ( $\mathrm{NaCl}, \mathrm{KCl}$, and $\mathrm{MgCl}_{2}$ added at a 45:45:10 mole ratio). Results from those tests, conducted with a $1 \mathrm{wt} \%$ chloride salt loading at $1000^{\circ} \mathrm{C}$, are also discussed.

\subsection{Material Balance}

Material balances were performed for each run (cycle) conducted at $750^{\circ} \mathrm{C}$, as discussed in Section 2.3.1. Cycles 51 and 52 used simulants containing $\mathrm{CeO}_{2}$ with $\mathrm{NaCl} / \mathrm{KCl}$; Cycles 53 and 54 used simulants containing $\mathrm{CeO}_{2}$ and $\mathrm{NaCl} / \mathrm{KCl} / \mathrm{MgCl}_{2}$. The mass of simulant in the boat was measured before and after each test. Figure 3.1 shows a loaded boat, with crucible and metal coupons, before and after calcination during Cycle 51. A mass balance was also performed around the offgas lines, the filter element, and the scrubber and condensate water. As expected, a direct material balance around the boat was found to be inconclusive. Corrosion products from the boat and metal coupons commingled with the calcined material in the boat. Consequently, to develop a more precise material balance, a cylindrical crucible was placed in the center of the boat in each run and was filled with simulant to the same level as that in the boat. The walls of the crucible thus minimized the amount of corrosion products mixing with the contents. Based on analyses of the material balance data, it was found that most of the mass lost from the simulants during calcination was removed from the boat in the form of acid chloride (e.g., $\mathrm{HCl}$ and iron/nickel chlorides), as compared to volatilization of intact chloride salts from the feed simulant (discussed below in greater detail).

Table 3.1 presents the material balances for Cycles 51 through 54. The first section of the Table 3.1, "Crucible Sample Mass Balance," provides the basis for calculating the quantity of chloride and chloride salt removed from the total simulant charged to the furnace. For the crucible mass balance analysis, the mass of the simulant in the crucible was accurately weighed before and after the furnace cycle, and the mass loss was determined by difference. The mass loss was then apportioned to three sources:

1) removal of moisture in the initial simulant; 2 ) removal of waters of hydration associated with $\mathrm{MgCl}_{2} \cdot 6 \mathrm{H}_{2} \mathrm{O}$; and 3) removal of chloride and chloride salt. The initial moisture content of the simulant was determined by heating samples of the $\mathrm{NaCl} / \mathrm{KCl}$ simulant to $500^{\circ} \mathrm{C}$ and measuring the weight loss. The initial moisture content $(0.0500 \mathrm{wt} \%)$ was used for both simulants, since $\mathrm{MgCl}_{2}$ is a relatively small fraction of the $\mathrm{NaCl} / \mathrm{KCl} / \mathrm{MgCl}_{2}$ simulant and heating the $\mathrm{NaCl} / \mathrm{KCl} / \mathrm{MgCl}_{2}$ simulant to $500^{\circ} \mathrm{C}$ would have resulted in loss of waters of hydration. All waters of hydration associated with the $\mathrm{MgCl}_{2} \cdot 6 \mathrm{H}_{2} \mathrm{O}$ in Cycles 53 and 54 were assumed to be removed during the furnace cycle (i.e., $4.22 \mathrm{wt} \%$ of the $\mathrm{NaCl} / \mathrm{KCl} / \mathrm{MgCl}_{2}$ salt consisted of waters of hydration; the source of $\mathrm{MgCl}_{2}$ used for preparing the simulant was $\mathrm{MgCl}_{2} \cdot 6 \mathrm{H}_{2} \mathrm{O}$. After accounting for the removal of initial moisture and waters of hydration, the remaining crucible sample mass loss was attributed to the removal of chloride and chloride salt. 


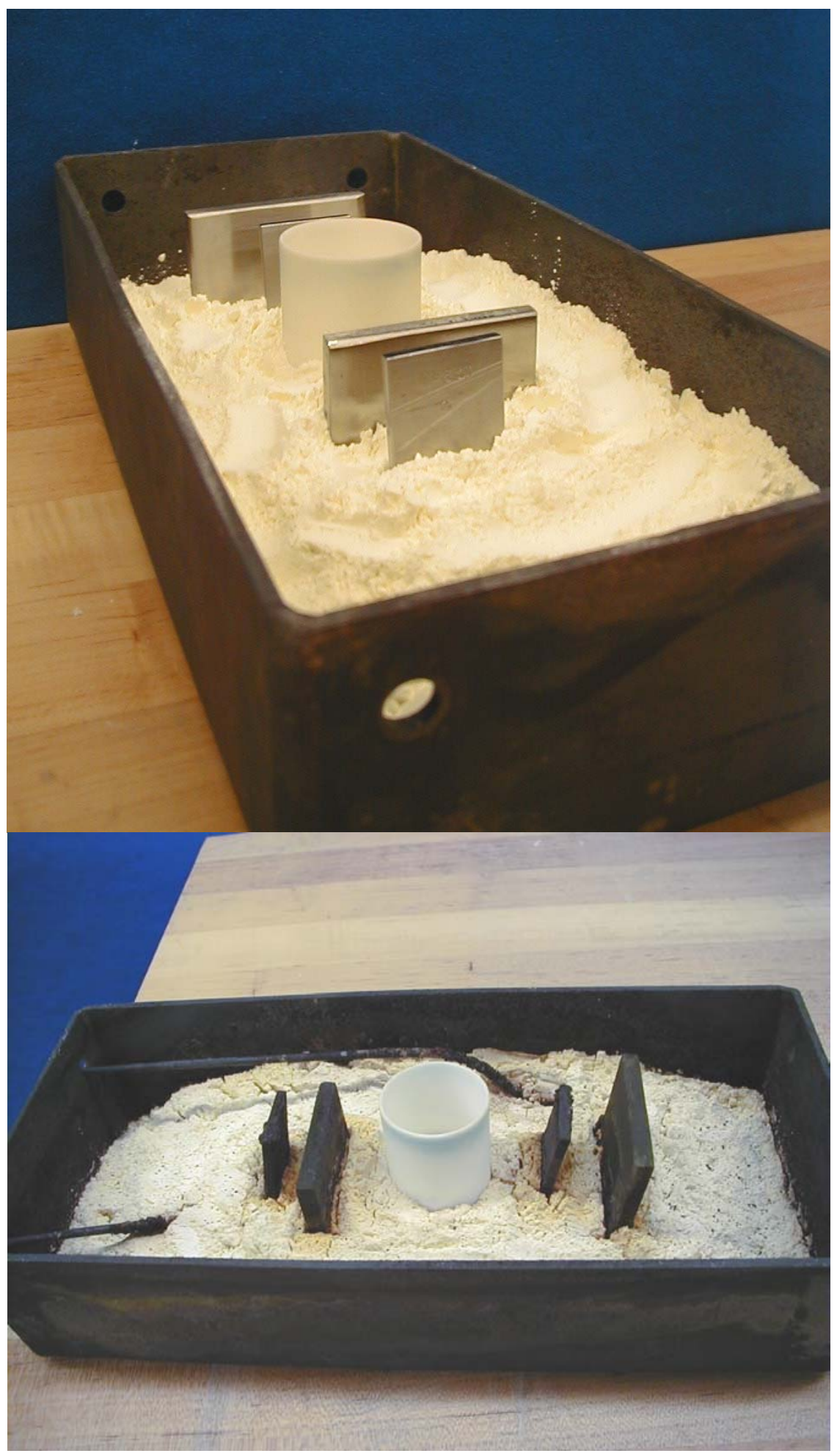

Figure 3.1. Cycle 51, Boat, Simulant, Coupons and Crucible, Before (top) and After (bottom) Calcination 
Table 3.1. Mass Balance for Cycles 51 Through 54

\begin{tabular}{|c|c|c|c|c|}
\hline & \multicolumn{2}{|c|}{$\mathrm{NaCl} / \mathrm{KCl}$} & \multicolumn{2}{|c|}{$\mathrm{NaCl} / \mathrm{KCl} / \mathrm{MgCl}_{2}$} \\
\hline Crucible Sample Mass Balance & Cycle 51 & Cycle 52 & Cycle 53 & Cycle 54 \\
\hline Initial (fresh) simulant in crucible, $g$ & 40.9637 & 39.6011 & 30.3204 & 31.5848 \\
\hline Calcined simulant in crucible, $g$ & 40.9074 & 39.5429 & 28.7248 & 29.9054 \\
\hline Moisture in fresh simulant, ${ }^{(\mathrm{a})} \mathrm{wt} \%$ & 0.0500 & 0.0500 & 0.0500 & 0.0500 \\
\hline Crucible simulant weight loss due to moisture removal, $\mathrm{g}$ & 0.0205 & 0.0198 & 0.0151 & 0.0158 \\
\hline $\begin{array}{l}\text { Crucible simulant weight loss due to removal of waters } \\
\text { of hydration associated with } \mathrm{MgCl}_{2} \cdot 6 \mathrm{H}_{2} \mathrm{O},{ }^{(\mathrm{b})} \mathrm{g}\end{array}$ & 0.0000 & 0.0000 & 1.2782 & 1.3315 \\
\hline $\begin{array}{l}\text { Crucible simulant weight loss due to removal of chloride } \\
\text { and chloride salt, g }\end{array}$ & 0.0358 & 0.0384 & 0.3022 & 0.3321 \\
\hline $\begin{array}{r}\text { Crucible simulant weight loss due to removal of chloride } \\
\text { and chloride salt, wt } \%\end{array}$ & 0.0875 & 0.0970 & 0.9968 & 1.0514 \\
\hline Simulant in Boat & Cycle 51 & Cycle 52 & Cycle 53 & Cycle 54 \\
\hline Simulant charge to boat, $\mathrm{g}$ & 1398.6 & 1399.4 & 1466.3 & 1464.7 \\
\hline Chloride salt in charge, $\mathrm{g}$ & 395.2 & 395.3 & 396.7 & 396.317 \\
\hline Chloride in charge, $\mathrm{g}$ & 210.7 & 210.7 & 223 & 222.8 \\
\hline $\begin{array}{l}\text { Calculated weight loss from boat, } \text {, }^{(c)} \text { based on crucible } \\
\text { wt\% loss, due to chloride and chloride salt removal, } g\end{array}$ & 1.22 & 1.36 & 14.62 & 15.40 \\
\hline Recovered Salt Mass $^{(\mathrm{d})}$ & Cycle 51 & Cycle 52 & Cycle 53 & Cycle 54 \\
\hline Chloride recovered from filter housing, $\mathrm{g}$ & 0 & 0 & 1.29 & 1.29 \\
\hline Chloride recovered from filter, $\mathrm{g}$ & 0.1720 & 0.1720 & 2.0571 & 2.4699 \\
\hline Chloride recovered from scrubber, $\mathrm{g}$ & 0.5203 & 0.7059 & 12.0660 & 12.2915 \\
\hline Chloride recovered from condenser, $\mathrm{g}$ & 0.0144 & 0.0018 & 0.1377 & 0.1107 \\
\hline Total chloride recol & 0.7067 & 0.8797 & 15.5509 & 16.1621 \\
\hline $\mathrm{Na}+\mathrm{K}+\mathrm{Mg}^{(\mathrm{e})}$ recovered from filter housing, $\mathrm{g}$ & 0 & 0 & 0.4890 & 0.4890 \\
\hline $\mathrm{Na}+\mathrm{K}+\mathrm{Mg}^{(\mathrm{e})}$ recovered from filter, $\mathrm{g}$ & 0.1876 & 0.1876 & 0.2506 & 0.3008 \\
\hline $\mathrm{Na}+\mathrm{K}+\mathrm{Mg}^{(\mathrm{e})}$ recovered from scrubber, $\mathrm{g}$ & 0.0698 & -0.0348 & 0.0334 & 0.0037 \\
\hline $\mathrm{Na}+\mathrm{K}+\mathrm{Mg}^{(\mathrm{e})}$ recovered from condenser, $\mathrm{g}$ & 0.0036 & 0.0009 & 0.0025 & 0.0017 \\
\hline Total $\mathrm{Na}+\mathrm{K}+$ Mg recovery, $g$ & 0.2610 & 0.1536 & 0.7755 & 0.7952 \\
\hline Total chloride $+\mathrm{Na}+\mathrm{K}+\mathrm{Mg}$ recovery, $g$ & 0.9677 & 1.0333 & 16.3263 & 16.9573 \\
\hline Total chloride $+\mathrm{Na}+\mathrm{K}+\mathrm{Mg}$ recovery, ${ }^{(f)} \%$ & 79.1 & 76.1 & $111.7^{(\mathrm{g})}$ & $110.1^{(\mathrm{g})}$ \\
\hline $\begin{array}{l}\text { (a) The initial moisture content of the simulant determine } \\
500^{\circ} \mathrm{C} \text { and measuring the weight loss. } \\
\text { (b) } 4.216 \mathrm{wt} \% \text { of } \mathrm{NaCl} / \mathrm{KCl} / \mathrm{MgCl}_{2} \text { simulant mass consist } \\
\mathrm{MgCl}_{2} \cdot 6 \mathrm{H}_{2} \mathrm{O} \text { used for the simulant makeup. } \\
\text { (c) } \mathrm{Based} \text { on extrapolation of the results from the crucible } \\
\text { (d) Chloride, } \mathrm{Na}, \mathrm{K} \text {, and } \mathrm{Mg} \text { quantities determined from I } \\
\text { solutions and from solutions generated by dissolving/ } \\
\text { housing. } \\
\text { (e) Although } \mathrm{Mg} \text { was present in } \mathrm{NaCl} / \mathrm{KCl} / \mathrm{MgCl}_{2} \text { simula } \\
\text { components. } \\
\text { (f) Total chloride }+\mathrm{Na}+\mathrm{K}+\mathrm{Mg} \text { recovery divided by } \mathrm{C} \\
\text { (g) This value would be reduced to } 89 \% \text { to } 91 \% \text { if the ma } \\
\mathrm{MgCl}_{2} \text {, assuming } 36 \% \text { to } 39 \% \text { decomposition) was ac } \\
\text { removal of chloride and chloride salt. }\end{array}$ & $\begin{array}{l}\text { by heating } \\
\text { of waters } \\
\text { ample mas } \\
\text { P and ISE a } \\
\text { aching soli } \\
\text { Mg was n } \\
\text { culated wet } \\
\text { of } \mathrm{O}_{2} \text { to fo } \\
\text { ounted for i }\end{array}$ & $\begin{array}{l}\text { mples of th } \\
\text { hydration } \\
\text { alance. } \\
\text { alysis of sc } \\
\text { recovered } \\
\text { detected in } \\
\text { ht loss from } \\
\text { ngO (du } \\
\text { the Calculc }\end{array}$ & $\begin{array}{l}\mathrm{NaCl} / \mathrm{KCl} \mathrm{s} \\
\text { sociated wi } \\
\text { ober and co } \\
\mathrm{m} \text { the filter } \\
\text { amples fron } \\
\text { oat } \mathrm{x} 100 \% \\
\mathrm{~g} \text { the decor } \\
\text { weight lo }\end{array}$ & $\begin{array}{l}\text { uulant to } \\
\text { the } \\
\text { enser } \\
\text { nd filter } \\
\text { ffgas } \\
\text { osition of } \\
\text { due to }\end{array}$ \\
\hline
\end{tabular}


The second section of Table 3.1, "Simulant in Boat," presents information on the mass and makeup of the total simulant charged to the boat. This portion of the table also provides the projected mass of chloride and chloride salt removed from the total charge, based on extrapolation of the results from the crucible sample mass balance. For Cycles 51 and 52, only $1.22 \mathrm{~g}$ and $1.36 \mathrm{~g}$, respectively, of chloride and chloride salt were removed from the boat. For Cycles 53 and 54, $14.62 \mathrm{~g}$ and $15.40 \mathrm{~g}$, respectively, of chloride and chloride salt were removed.

The third section of Table 3.1, "Recovered Salt Mass," accounts for the chloride and $\mathrm{Na}+\mathrm{K}+\mathrm{Mg}$ recovered in the offgas system components (filter housing, filter, scrubber, and condenser). It was found that $\mathrm{Mg}$ was below analytical detection limits in all samples collected from offgas components. Very small weight changes were observed in the offgas lines, with most of the changes likely the result of corrosion. However, routine cleaning/sampling of the offgas lines was not performed between cycles to allow for a multi-cycle assessment of the operability of the offgas lines. Consequently, Table 3.1 does not include recoveries from the offgas lines. For Cycles 51 and 52, Table 3.1 shows that between 0.70 and $0.88 \mathrm{~g}$ of chloride was recovered in the offgas system, with $75 \%$ to $80 \%$ of the chloride recovered in the scrubber water and condensate. Based on the chloride and $\mathrm{Na}+\mathrm{K}+\mathrm{Mg}$ recovery measurements, during Cycles 51 and 52,79.1\% and 76.1\%, respectively, of the chloride and chloride salt removed from the charges were recovered in the offgas system. For Cycles 53 and 54, about $112 \%$ and $110 \%$, respectively, of the chloride and chloride salt removed from the simulant were recovered in the offgas system. Part of the over-recovery of chloride and chloride salt in Cycles 53 and 54 can be attributed to underestimating the quantity of chloride and chloride salt removed from the charge. Oxygen, which is not accounted for in Table 3.1, is added to the charge mass as a result of the formation of $\mathrm{MgO}$ during the decomposition of $\mathrm{MgCl}_{2}$. The weight gain associated with the oxygen offsets and masks some of the weight loss associated with the removal of chloride and chloride salt. Assuming that $36 \%$ to $39 \%$ of the $\mathrm{MgCl}_{2}$ decomposed (as shown below), and accounting for the oxygen added to the simulant, the recoveries for Cycles 53 and 54 would be $89 \%$ to $91 \%$.

Table 3.2 shows the relative mole fractions of $\mathrm{Na}, \mathrm{K}$, and $\mathrm{Mg}$ (derived from ICP data) in samples of feed and calcined samples. The mole fraction data on the feed simulants are in excellent agreement with the target mole ratios established for the simulant makeup (i.e., $\mathrm{NaCl}$ and $\mathrm{KCl}$ added at a 50:50 mole ratio for Cycles 51 and 52; and $\mathrm{NaCl}, \mathrm{KCl}$, and $\mathrm{MgCl}_{2}$ added at a 45:45:10 mole ratio for Cycles 53 and 54, see

Table 2.1). Both the feed and calcined simulants from Cycles 51 and 53 contained essentially equimolar concentrations of $\mathrm{Na}$ and $\mathrm{K}$ (i.e., no selective depletion of either $\mathrm{Na}$ or $\mathrm{K}$ occurred during calcination). This behavior is expected since only a very small portion of the salts in the simulant was volatilized during calcinations.

The $\mathrm{Mg}$ concentration in the calcined simulant from Cycle 53 is significantly lower than that in the feed simulant. This suggests that either $\mathrm{MgCl}_{2}$ preferentially volatilized during calcining or it decomposed to form $\mathrm{HCl}$ and $\mathrm{MgO} / \mathrm{Mg}(\mathrm{OH})_{2}$. In the latter case, the $\mathrm{MgO} / \mathrm{Mg}(\mathrm{OH})_{2}$ that formed from the decomposition of $\mathrm{MgCl}_{2}$ would not leach ${ }^{(\mathrm{a})}$ to any significant degree (supported by the leachate $\mathrm{pH}$ of 9.41). The magnitude of the $\mathrm{Mg}$ depletion indicates that about $36 \%$ to $39 \%$ of the $\mathrm{MgCl}_{2}$ may have decomposed to form $\mathrm{MgO}$. This level of decomposition corresponds to the removal of 14.7 to $16.0 \mathrm{~g}$ of chloride

(a) Leaching was performed to prepare samples for chemical analyses. Feed simulant samples (uncalcined) were prepared for analyses of chloride by ISE and $\mathrm{Na} / \mathrm{K} / \mathrm{Mg}$ by ICP by grinding a nominal $15-\mathrm{g}$ sample in a mortar and pestle to homogenize the samples, and then taking a nominal 1.00-g subsample for leaching in $100 \mathrm{ml}$ of deionized water. Calcined simulant recovered from the crucibles (entire sample) were dissolved in $500 \mathrm{ml}$ of deionized water. The slurries were filtered to remove the suspended solids, and the $\mathrm{pHs}$ of resulting leachates were measured. 
Table 3.2. Relative Mole Fractions of $\mathrm{Na}, \mathrm{K}$, and $\mathrm{Mg}$ in Feed and Calcined Simulants

\begin{tabular}{|c|c|c|c|c|c|}
\hline \multirow[b]{3}{*}{ Analyte } & \multicolumn{2}{|c|}{ Cycle 51 Simulant } & \multicolumn{2}{|c|}{ Cycle 53 Simulant } & \multirow{2}{*}{$\begin{array}{c}\text { Cycle } 54 \\
\text { Simulant } \\
\text { Feed } \\
\end{array}$} \\
\hline & Feed & Calcined & Feed & Calcined & \\
\hline & \multicolumn{5}{|c|}{ Mole Fraction } \\
\hline $\mathrm{Na}$ & 0.499 & 0.494 & 0.448 & 0.462 & 0.448 \\
\hline $\mathrm{K}$ & 0.501 & 0.506 & 0.444 & 0.472 & 0.449 \\
\hline $\mathrm{Mg}$ & 0.00 & 0.00 & 0.108 & 0.0664 & 0.104 \\
\hline Total & 1.00 & 1.00 & 1.00 & 1.00 & 1.00 \\
\hline
\end{tabular}

(chloride in $\mathrm{MgCl}_{2}$ within the feed simulant $=40.9 \mathrm{~g}$ ), assuming the chloride in the decomposed $\mathrm{MgCl}_{2}$ left the boat in the form of $\mathrm{HCl}$. Further, this level of chloride removal is consistent with the quantity of chloride recovered (15.5 g) in the offgas system during Cycle 53 (Table 3.1). Also, a $36 \%$ to $39 \% \mathrm{MgCl}_{2}$ decomposition in Cycle 53 would correspond to 3.3 to $3.6 \mathrm{~g}$ of oxygen being added to the charge mass. The test conditions and overall chloride removal results from Cycles 51 through 54 are summarized in Table 3.3. For comparison, some results from the previous furnace testing at $1000^{\circ} \mathrm{C}$ with $1 \mathrm{wt} \%$ chloride salt as $\mathrm{NaCl} / \mathrm{KCl} / \mathrm{MgCl}_{2}$ (Fischer et al. 2002) are also provided.

Table 3.3. Test Conditions and Chloride Removal

\begin{tabular}{|c|c|c|c|c|c|c|c|}
\hline \multirow[b]{2}{*}{$\begin{array}{l}\text { Cycle } \\
\text { No. }\end{array}$} & \multirow[b]{2}{*}{$\begin{array}{c}\text { Furnac } \\
\text { e Hold } \\
\text { Temp., } \\
\quad{ }^{\circ} \mathrm{C}\end{array}$} & \multicolumn{2}{|c|}{ Chloride Salt in Simulant } & \multicolumn{2}{|c|}{$\begin{array}{l}\text { Mass of Chloride and } \\
\text { Chloride Salt Lost } \\
\text { from Simulant in Boat }\end{array}$} & \multicolumn{2}{|c|}{$\begin{array}{c}\% \text { of Chloride Removed } \\
\text { from Boat }\end{array}$} \\
\hline & & $\begin{array}{c}\text { Mass in } \\
\text { Charge } \\
, \mathrm{g}\end{array}$ & $\begin{array}{c}\text { Mole ratio, } \\
\text { NaCl:KCl: } \mathbf{M g C l}_{2} \\
\end{array}$ & $\begin{array}{c}\text { Gram } \\
\text { per } \\
\text { Charge }^{(a)} \\
\end{array}$ & $\begin{array}{c}\text { As \% of } \\
\text { Chloride } \\
\text { Salt in } \\
\text { Charge }^{(b)} \\
\end{array}$ & $\begin{array}{l}\text { Chloride } \\
\text { Chemical } \\
\text { Analysis }^{(c}\end{array}$ & $\begin{array}{c}\text { Based on } \\
\text { Chloride } \\
\text { Recovered } \\
\text { (d) }\end{array}$ \\
\hline 51 & 750 & 395.2 & 50:50:0 & 1.22 & 0.309 & \multirow{2}{*}{ [Note e] } & 0.34 \\
\hline 52 & 750 & 395.3 & 50:50:0 & 1.36 & 0.344 & & 0.42 \\
\hline 53 & 750 & 396.7 & $45: 45: 10$ & 14.62 & 3.69 & \multirow{2}{*}{13.2} & 6.97 \\
\hline 54 & 750 & 396.3 & $45: 45: 10$ & 15.40 & 3.89 & & 7.25 \\
\hline $2-7$ & 1000 & 16 & $45: 4$ & $15.6^{*}$ & No data & 97.5 & No data \\
\hline 9 (front) & 1000 & 16 & $45: 45: 10$ & $15.7^{*}$ & No data & 98.4 & No data \\
\hline 9 (back) & 1000 & 16 & $45: 45: 10$ & $15.6^{*}$ & No data & 97.6 & No data \\
\hline 34 & 1000 & 20 & $45: 45: 10$ & 16.6 & 83 & No data & No data \\
\hline 35 & 1000 & 20.1 & $45: 45: 10$ & 16.5 & 82 & 66.3 & No data \\
\hline 36 & 1000 & 20.1 & $45: 45: 10$ & 20.0 & 99.7 & 72.4 & No data \\
\hline \multicolumn{8}{|c|}{$\begin{array}{l}\text { (a) Values from Cycles } 51 \text { through } 54 \text { taken from Table } 1 \text {. Values marked with * were determined based on } \\
\text { chloride analyses and by assuming chloride and chloride salt losses are proportional. } \\
\text { (b) = } 100 \% \text { x Mass of Chloride and Chloride Salt Lost from Simulant in Boat (g/charge) divided by Chloride } \\
\text { Salt in Simulant. } \\
\text { (c) Values based on measured chloride (ISE) content in feed simulant and calcined simulant. } \\
\text { (d) Values based on recovery of chloride from materials collected in the filter, filter housing, scrubber water, } \\
\text { and condensate (see Table } 1 \text { ). } \\
\text { (e) Due to analytical uncertainty introduced in sample preparation and ISE analyses, and the very small } \\
\text { difference between the feed and calcined sample, no measurable difference in chloride content was found } \\
\text { between the feed and calcined material. }\end{array}$} \\
\hline
\end{tabular}


Table 3.3 compares values for the masses of chloride and chloride salt removed from the charge during the present and prior calcination testing (for Cycles 51 through 54, these values were taken from Table 3.1). To compare the furnace cycles, the mass losses of chloride and chloride salt are also presented as percent of the initial chloride salts in the feed charge.

Table 3.3 also presents the results of two techniques used to estimate the amount of chloride removed from the charge during calcination. In the first technique, chloride removal was estimated by leaching the feed simulant and the calcined simulant taken from the crucible, and measuring the chloride content in the leachate with an ISE. This technique provides a reasonably accurate estimate of chloride removal when a significant quantity of chloride has been removed.

For the second technique, chloride removal was estimated by knowing the chloride content in the feed simulant and measuring the chloride captured in the various components of the offgas system. Assuming all chloride removed from the simulant in the charge was captured, this technique provides a reasonably accurate estimate of chloride removal.

For Cycles 51 and 52, both the feed and the calcined simulant contained high concentrations of chloride, and very little chloride removal occurred. Consequently, use of the first technique did not provide a reliable chloride removal estimate for these two tests. During Cycles 51 and 52, the observed carry-over of salts and liquid beyond the condenser was minimal; therefore, most of the chloride removed from the charges was captured. Good recoveries were also demonstrated by the mass balance (Table 3.1). Consequently, the second technique, based on chloride recovery measurements, should have provided reasonably accurate estimates for percent chloride removal for Cycles 51 and 52, found to be 0.34 and $0.42 \mathrm{wt} \%$, respectively.

Based on the feed makeup, the simulant charged to the boat in Cycles 53 and 54 should have contained $223 \mathrm{~g}$ of chloride. ISE results indicated that the feed simulant and calcined product material contained $229 \mathrm{~g}$ and $199 \mathrm{~g}$ chloride, respectively (i.e., $\sim 30 \mathrm{~g}$, or 13\%, of chloride was removed, based on the first technique). During Cycles 53 and 54, a small amount (several $\mathrm{ml}$ ) of liquid carry-over into the flow meter was noted while the furnace was being ramped to $750^{\circ} \mathrm{C}$, but acid was not detected when litmus paper was placed in the offgas blower exhaust. Chloride recovery measurements indicate that 6.97 to $7.25 \mathrm{wt} \%$ of the chloride was removed from the charge during Cycles 53 and 54. Considering the errors associated with the ISE measurements of chloride in the feed and calcined product (measurement of relatively small differences between large values), the chloride removal estimates based on the chloride recovery measurements are probably more accurate for Cycles 53 and 54.

For Cycles 2 through 7, 9, 35, and 36, conducted at $1000^{\circ} \mathrm{C}$ with $\mathrm{NaCl} / \mathrm{KCl} / \mathrm{MgCl}_{2}$, use of the first technique to estimate chloride removal provides reasonably accurate values (i.e., measurement of relatively large differences between chloride content in feed and calcined material).

Table 3.3 shows that very small quantities of chloride and chloride salt were removed during Cycles 51 and $52\left(\mathrm{NaCl} / \mathrm{KCl}\right.$ at $\left.750^{\circ} \mathrm{C}\right)$. In contrast, the masses of chloride and chloride salt removed during Cycles 53 and $54\left(\mathrm{NaCl} / \mathrm{KCl} / \mathrm{MgCl}_{2}\right.$ simulant at $\left.750^{\circ} \mathrm{C}\right)$ are comparable to the masses removed when the furnace was charged with 16 to $20 \mathrm{~g}$ of the same chloride salt mix and operated at $1000^{\circ} \mathrm{C}$ in the previous testing. 
During Cycles 51 through 54, only a small fraction of the chloride in the charge was removed at $750^{\circ} \mathrm{C}$. In Cycles 2 through 7 and $9\left(1000^{\circ} \mathrm{C}\right)$, which included $16 \mathrm{~g}$ of chloride salt in the charge, essentially all of the chloride was removed. However, in Cycles 35 and 36 (also at $1000^{\circ} \mathrm{C}$ ), which included $20 \mathrm{~g}$ of chloride salt in the charge, only $\sim 70 \%$ of the chloride was removed.

\subsection{Scrubber/Condenser Water Analysis}

\subsubsection{Cycles 51 and 52 ( $\mathrm{NaCl}$ and $\mathrm{KCl}$ Simulant)}

Before Cycle 51, the offgas scrubber was cleaned, then loaded with $22.72 \mathrm{~kg}$ deionized water. A sample of the fresh scrubber water was collected. Scrubber water and condensate samples were also collected after Cycles 51 and 52. The scrubber water was not replaced or neutralized between Cycles 51 and 52. The results of the ICP and ISE analyses of scrubber and condenser water samples are given in Table 3.4. The measured $\mathrm{pH}$ values for these samples and the chloride concentrations that would be associated with $\mathrm{HCl}$ based on these $\mathrm{pH}$ values are also provided. With the exception of chloride, the concentrations of the analytes measured in the scrubber water were very low. The data indicate that small quantities of $\mathrm{Na}$ and $\mathrm{K}$ were captured in the scrubber during Cycle 51. However, the concentration of $\mathrm{Na}$ and $\mathrm{K}$ decreased slightly during Cycle 52. As noted in past observations, small quantities of salts initially pass through new stainless steel pleated filters, but after a coating/cake of salts is laid down on the filter, no further salt penetration occurs.

Assuming all measured $\mathrm{Na}$ and $\mathrm{K}$ in Cycle 51 scrubber water (in excess of that measured in the fresh scrubber water) entered the scrubber as salts, then $123 \mathrm{mg}$ and $41 \mathrm{mg}$ of $\mathrm{NaCl}$ and $\mathrm{KCl}$, respectively, were captured in the scrubber. The total chloride in the scrubber associated with the projected $\mathrm{NaCl}$ and $\mathrm{KCl}$ is $\sim 94 \mathrm{mg}$. In comparison, based on the chloride data (ISE), the scrubber contained a total of $540 \mathrm{mg}$ chloride (with $\sim 390 \mathrm{mg}$ associated with $\mathrm{HCl}$ ). These data suggest that $\sim 0.2 \%$ of the chloride in the feed simulant (224 g) was converted to $\mathrm{HCl}$ (via pyrohydrolysis).

Table 3.4. Analyte Concentrations in Scrubber and Condenser Water - Cycles 51 and 52 $(\mathrm{NaCl} / \mathrm{KCl}$ Simulant)

\begin{tabular}{|c|c|c|c|c|c|}
\hline \multirow[b]{3}{*}{ Analyte } & \multicolumn{3}{|c|}{ Scrubber Water } & \multicolumn{2}{|c|}{ Condenser Water } \\
\hline & $\begin{array}{c}\text { Pre Cycle } 51 \\
\text { Fresh }\end{array}$ & $\begin{array}{c}\text { Post Cycle } 51 \\
\text { Spent }\end{array}$ & $\begin{array}{c}\text { Post Cycle } 52 \\
\text { Spent }\end{array}$ & Post Cycle 51 & Post Cycle 52 \\
\hline & \multicolumn{5}{|c|}{ Concentration, $\mathrm{mg} / \mathrm{L}$} \\
\hline $\mathrm{B}$ & 2.028 & 3.502 & 3.807 & 3.675 & 4.272 \\
\hline $\mathrm{Ca}$ & $<\operatorname{det}$ & $<\operatorname{det}$ & 1.474 & 1.500 & $<\operatorname{det}$ \\
\hline $\mathrm{Cr}$ & $<\operatorname{det}$ & 0.248 & $<\operatorname{det}$ & $<\operatorname{det}$ & $<\operatorname{det}$ \\
\hline $\mathrm{Cu}$ & $<\operatorname{det}$ & $<\operatorname{det}$ & $<\operatorname{det}$ & 1.285 & $<\operatorname{det}$ \\
\hline $\mathrm{Fe}$ & $<\operatorname{det}$ & $<\operatorname{det}$ & 2.257 & 29.266 & 0.251 \\
\hline $\mathrm{K}$ & 0.457 & 1.409 & 0.565 & 16.148 & 0.958 \\
\hline $\mathrm{Mn}$ & $<$ det & $<$ det & $<$ det & 3.440 & $<$ det \\
\hline $\mathrm{Na}$ & 3.975 & 6.094 & 5.411 & 11.520 & 5.578 \\
\hline $\mathrm{Ni}$ & $<\operatorname{det}$ & $<\operatorname{det}$ & $<\operatorname{det}$ & 24.108 & 3.100 \\
\hline $\mathrm{Si}$ & 6.346 & 1.792 & 2.041 & 3.005 & 2.473 \\
\hline $\begin{array}{c}\text { Chloride } \\
\text { (ISE) }\end{array}$ & NA & 23.8 & 55.3 & 111.3 & 14.0 \\
\hline $\mathrm{pH}$ & 6.8 & 3.31 & 2.98 & 3.64 & 4.05 \\
\hline $\begin{array}{c}\text { Acid } \\
\text { Derived } \\
\text { Chloride }\end{array}$ & NA & 17 & 37 & 8 & 3 \\
\hline
\end{tabular}


Approximately $720 \mathrm{mg}$ of chloride were collected in the scrubber water during Cycle 52. The chloride content predicted to be associated with $\mathrm{HCl}$ based on the $\mathrm{pH}$ of the scrubber water was $450 \mathrm{mg}$. Considering that little or no $\mathrm{Na}, \mathrm{K}, \mathrm{Fe}$, or $\mathrm{Cr}$ accumulated in the scrubber water during Cycle $52, \mathrm{HCl}$, generated from pyrohydrolysis of $\mathrm{NaCl}$ and $\mathrm{KCl}$, is the probable source for most of the $720 \mathrm{mg}$ of chloride.

During Cycles 51 and 52,131 g and $132 \mathrm{~g}$ of condensate, respectively, were collected. There is a small but significant concentration of $\mathrm{Fe}, \mathrm{Ni}$, and chloride in the Cycle 51 condensate water. The relatively low $\mathrm{pH}$ of the condensate solution could have resulted in some minor corrosion of the stainless steel condenser (i.e., potential source of $\mathrm{Fe}$ and $\mathrm{Ni}$ ). Minor concentrations of $\mathrm{Mn}$ and $\mathrm{Cu}$ are also probably corrosion products. The presence of $\mathrm{Na}$ and $\mathrm{K}$ in the condenser water is attributed to aerosols containing these analytes passing uncaptured through the scrubber or accompanying aerosols generated by the scrubber.

\subsubsection{Cycles 53 and 54 ( $\mathrm{NaCl}, \mathrm{KCl}$, and $\mathrm{MgCl}_{2}$ Simulant)}

Before Cycles 53 and 54, the offgas scrubber was cleaned and then filled with 20.01 and $20.15 \mathrm{~kg}$ of deionized water, respectively. Samples of the fresh scrubber water were collected. Two spent scrubber water samples were collected during each cycle. The first sample was collected immediately after completing the $2-\mathrm{hr}$ hold time at $750^{\circ} \mathrm{C}$. The second sample was collected after the furnace had cooled to about $400^{\circ} \mathrm{C}$. During the cooling period, offgas flow through the furnace was continued. Condenser water was also collected after each cycle. The results of the ICP and ISE analyses of scrubber and condenser water samples are given in Table 3.5. The measured $\mathrm{pH}$ values for these samples and the

Table 3.5. Analyte Concentrations in Scrubber and Condenser Water - Cycles 53 and 54 $\left(\mathrm{NaCl} / \mathrm{KCl} / \mathrm{MgCl}_{2}\right.$ Simulant)

\begin{tabular}{|c|c|c|c|c|c|c|c|c|}
\hline \multirow{3}{*}{ Analyte } & \multicolumn{3}{|c|}{ Cycle 53 Scrubber Water } & \multicolumn{3}{|c|}{ Cycle 54 Scrubber Water } & \multicolumn{2}{|c|}{ Condenser Water } \\
\hline & \multicolumn{8}{|c|}{ Concentration, mg/L } \\
\hline & Fresh & $\begin{array}{c}\text { Spent } \\
\left(\text { at } 750^{\circ} \mathrm{C}\right)\end{array}$ & $\begin{array}{l}\text { Spent } \\
\text { (final) }\end{array}$ & Fresh & $\begin{array}{c}\text { Spent } \\
\left(\text { at } 750^{\circ} \mathrm{C}\right)\end{array}$ & $\begin{array}{l}\text { Spent } \\
\text { (final) }\end{array}$ & Cycle 53 & Cycle 54 \\
\hline B & 2.370 & 2.877 & 2.148 & 2.184 & 1.292 & $<\operatorname{det}$ & 1.429 & 1.521 \\
\hline $\mathrm{Ca}$ & $<\operatorname{det}$ & $<\operatorname{det}$ & $<\operatorname{det}$ & $<\operatorname{det}$ & $<\operatorname{det}$ & $<\operatorname{det}$ & 1.738 & 1.021 \\
\hline $\mathrm{Cr}$ & $<$ det & 1.300 & 2.176 & $<\operatorname{det}$ & 1.757 & 3.222 & 8.503 & 22.032 \\
\hline $\mathrm{Cu}$ & $<\operatorname{det}$ & $<$ det & $<$ det & $<\operatorname{det}$ & $<\operatorname{det}$ & $<$ det & 2.234 & 1.171 \\
\hline $\mathrm{Fe}$ & $<\operatorname{det}$ & 4.655 & 7.963 & $<\operatorname{det}$ & 6.916 & 12.511 & 91.211 & 113.220 \\
\hline $\mathrm{K}$ & 0.095 & 1.154 & 1.745 & $<\operatorname{det}$ & $<\operatorname{det}$ & $<\operatorname{det}$ & 9.977 & 6.277 \\
\hline $\mathrm{Mg}$ & $<\operatorname{det}$ & $<\operatorname{det}$ & $<$ det & $<\operatorname{det}$ & $<$ det & $<\operatorname{det}$ & $<\operatorname{det}$ & $<\operatorname{det}$ \\
\hline $\mathrm{Mn}$ & $<\operatorname{det}$ & $<$ det & $<\operatorname{det}$ & $<\operatorname{det}$ & $<\operatorname{det}$ & $<$ det & 2.608 & 1.718 \\
\hline Mo & $<\operatorname{det}$ & $<$ det & $<$ det & $<\operatorname{det}$ & $<$ det & $<$ det & $<\operatorname{det}$ & 2.657 \\
\hline $\mathrm{Na}$ & 3.660 & 5.822 & 5.331 & 3.309 & 3.959 & 3.491 & 8.524 & 6.622 \\
\hline $\mathrm{Ni}$ & $<\operatorname{det}$ & $<$ det & 1.201 & $<\operatorname{det}$ & 1.004 & 1.835 & 11.453 & 9.488 \\
\hline $\mathrm{Si}$ & 6.169 & 2.433 & 2.085 & 6.261 & 1.310 & 1.229 & 2.500 & 2.522 \\
\hline $\begin{array}{l}\text { Chloride } \\
\text { (ISE) }\end{array}$ & & 415 & 603 & & 393 & 610 & 1021 & 858 \\
\hline $\mathrm{pH}$ & 7.49 & 1.92 & 1.77 & 6.5 & 2.08 & 1.93 & 1.57 & 1.98 \\
\hline $\begin{array}{c}\text { Acid } \\
\text { Derived } \\
\text { Chloride }\end{array}$ & NA & 426 & 602 & NA & 295 & 417 & 954 & 371 \\
\hline
\end{tabular}


chloride concentrations that would be associated with $\mathrm{HCl}$ based on these $\mathrm{pH}$ values are also provided. With the exception of chloride, the concentrations of the other analytes measured in the scrubber water were very low. The data indicate that small quantities of $\mathrm{Na}$ and $\mathrm{K}$ were captured in the scrubber during Cycle 53, but essentially no $\mathrm{Na}, \mathrm{K}$, or $\mathrm{Mg}$ was captured in the scrubber water during Cycle 54. The chloride captured in the scrubber during Cycle 53 is two orders of magnitude greater than that of the $\mathrm{Na}$ and $\mathrm{K}$. The data are consistent with $\mathrm{HCl}$ as the source of essentially all of the chloride in the scrubber.

Low concentrations of $\mathrm{Fe}, \mathrm{Cr}$, and $\mathrm{Ni}$ were observed in the scrubber, and it is possible that some of these entered the scrubber as chloride salt. However, these analytes could also be attributable to minor corrosion of the stainless steel scrubber vessel.

There is very good agreement between the ISE chloride concentrations and the chloride associated with $\mathrm{HCl}$ based on the $\mathrm{pH}$ measurements for Cycle 53 scrubber and condenser water, supporting that $\mathrm{HCl}$ is the source for most of the chloride in these samples. The $\mathrm{pH}$-based $\mathrm{HCl}$ concentrations do not compare as well with the ISE measurements for Cycle 54 scrubber and condenser water, but still suggest that $\mathrm{HCl}$ is the predominant chloride source.

In Cycles 53 and 54, the chloride concentration in the second scrubber sample was about 50\% greater than the concentration in the first sample. This strongly supports that significant amounts of $\mathrm{HCl}$ were evolved from the simulant during cooldown.

During Cycles 53 and 54, $135 \mathrm{~g}$ and $129 \mathrm{~g}$, respectively, of condensate were collected. Small but significant concentrations of $\mathrm{Fe}, \mathrm{Cr}$, and $\mathrm{Ni}$ present in the condenser water can likely be attributed to corrosion of the condenser vessel. The trace accumulations of $\mathrm{Ca}, \mathrm{Cu}, \mathrm{Mn}$, and Co shown in Table 3.5 were not measurable in the scrubber water. The presence of $\mathrm{Na}$ and $\mathrm{K}$ in the condenser water is attributed to aerosols containing these analytes passing through or generated in the scrubber.

\subsubsection{Cycle 13 Previous Furnace Testing at $1000^{\circ} \mathrm{C}\left(\mathrm{NaCl}, \mathrm{KCl}\right.$, and $\mathrm{MgCl}_{2} \mathrm{Simulant}$}

During the previous furnace testing, chemical analyses were performed on scrubber water before and after Cycle 13 but were not reported in Fischer et al. (2002). For Cycle 13, the furnace was charged with $1016 \mathrm{~g}$ of simulant that included $16 \mathrm{~g}$ of chloride salt $\left(\mathrm{NaCl}, \mathrm{KCl}\right.$, and $\mathrm{MgCl}_{2}$ added at a mole ratio of 45:45:10). The masses of the individual chloride salts in the charge were: $\mathrm{NaCl}, 6.08 \mathrm{~g} ; \mathrm{KCl}, 7.76 \mathrm{~g}$; and $\mathrm{MgCl}_{2}, 2.20 \mathrm{~g}$. For Cycle 13, the furnace was ramped to and held at $1000^{\circ} \mathrm{C}$ for $2 \mathrm{hr}$. Based on analyses of the calcined product from similar runs (Cycles 2 through 7 and 9, Table 3.3), nearly all of the chloride in Cycle 13 should have been removed from the charge during the processing. Unlike the filter used in Cycles 51 through 54, a packed knockout pot was used in Cycle 13 to remove particulate from the offgas stream. The particle removal efficiency of the knockout pot was much lower than that of the 5- $\mu \mathrm{m}$ filter, allowing more chloride salt into the scrubber.

Before Cycle 13, the scrubber was cleaned and then filled with $23.4 \mathrm{~kg}$ of tap water. Samples of the fresh scrubber water were collected and analyzed (Table 3.6). The measured $\mathrm{pH}$ values for these samples and the chloride concentrations that would be associated with $\mathrm{HCl}$ based on these $\mathrm{pH}$ values are also provided. As expected, due to the use of the knockout pot and the higher furnace temperature, the concentrations of $\mathrm{Na}$ and $\mathrm{K}$ in the spent Cycle 13 scrubber water are significantly higher than those measured in the spent scrubber water from Cycles 51 through 54. 
Table 3.6. Analyte Concentrations in Scrubber Water - Cycle 13 (Previous Furnace Testing; $\mathrm{NaCl} / \mathrm{KCl} / \mathrm{MgCl}_{2}$ Simulant, $1 \mathrm{wt} \%$ Chloride Salt, $1000^{\circ} \mathrm{C}$ )

\begin{tabular}{|c|c|c|}
\hline \multirow[b]{2}{*}{ Analyte } & \multicolumn{2}{|c|}{ Cycle 13 Scrubber Water } \\
\hline & $\begin{array}{c}\text { Pre Cycle } 13 \text { Fresh, } \\
\mathrm{mg} / \mathrm{L}\end{array}$ & $\begin{array}{c}\text { Post Cycle } 13 \text { Spent } \\
\mathrm{mg} / \mathrm{L}\end{array}$ \\
\hline $\mathrm{Al}$ & $<$ det & 0.240 \\
\hline $\mathrm{B}$ & 2.676 & 5.214 \\
\hline $\mathrm{Ca}$ & 17.482 & 20.587 \\
\hline $\mathrm{Ce}$ & $<$ det & $<$ det \\
\hline $\mathrm{Cr}$ & $<$ det & 0.803 \\
\hline $\mathrm{Cu}$ & $<$ det & 0.506 \\
\hline $\mathrm{Fe}$ & 0.585 & 3.183 \\
\hline $\mathrm{K}$ & 2.872 & 13.291 \\
\hline $\mathrm{Mg}$ & 4.040 & 4.212 \\
\hline $\mathrm{Mn}$ & $<$ det & $<$ det \\
\hline Mo & 0.270 & 1.349 \\
\hline $\mathrm{Na}$ & 5.712 & 14.169 \\
\hline $\mathrm{Ni}$ & $<$ det & 0.514 \\
\hline $\mathrm{S}$ & 2.224 & 2.254 \\
\hline $\mathrm{Si}$ & 6.241 & 5.297 \\
\hline $\mathrm{Zn}$ & $<$ det & 0.410 \\
\hline Chloride (ISE) & 18.58 & 153.14 \\
\hline $\mathrm{pH}$ & 7.55 & 2.59 \\
\hline Acid Derived Chloride & -- & 91 \\
\hline
\end{tabular}

Table 3.7 shows a chloride mass balance performed around the scrubber water, which was based on the composition of the Cycle 13 simulant charge, the mass of scrubber water, and the data in Table 3.6. For analysis of the sources of chloride in the scrubber, it was assumed that $100 \%$ of the chloride in the $\mathrm{MgCl}_{2}$ (from the simulant charge) was captured in the scrubber as $\mathrm{HCl}$ (i.e., $\mathrm{MgCl}_{2}$ underwent pyrohydrolysis in the furnace). It was also assumed that all measured $\mathrm{Na}, \mathrm{K}, \mathrm{Fe}$, and $\mathrm{Cr}$ in the scrubber water (in excess of that measured in the fresh scrubber water) entered the scrubber as chloride salt. The mass of chloride in the scrubber water measured by ISE $(3.15 \mathrm{~g})$ exceeded the mass of chloride that could be attributed to the sources listed in Table 3.7 (2.33 g). The only other possible source for the balance of chloride in the scrubber water $(0.82 \mathrm{~g})$ is $\mathrm{HCl}$ generated from the decomposition (pyrohydrolysis) of some of the $\mathrm{NaCl}$ and $\mathrm{KCl}$. The sum of the chloride derived from $\mathrm{MgCl}_{2}$ decomposition and the chloride derived from pyrohydrolysis of $\mathrm{NaCl}$ and $\mathrm{KCl}(1.64 \mathrm{~g}+0.82 \mathrm{~g}=2.46 \mathrm{~g})$ is comparable to the acid-derived chloride value $(2.13 \mathrm{~g})$, which supports that most of this chloride entered the scrubber in the form of $\mathrm{HCl}$. In comparing the scrubber water analysis results from Cycle 13 with those of Cycles 51 and 52, the estimated quantity of $\mathrm{HCl}$ generated from pyrohydrolysis of $\mathrm{NaCl}$ and $\mathrm{KCl}$ in Cycle 13 is greater than the amounts estimated in Cycles 51 and 52 ( $0.39 \mathrm{~g}$ and $0.72 \mathrm{~g}$, respectively). This finding suggests that $\mathrm{HCl}$ generation from pyrohydrolysis of $\mathrm{NaCl}$ and $\mathrm{KCl}$ in unwashed $\mathrm{HCP}$ items (with nominal $20 \mathrm{wt} \%$ salt) processed at $750^{\circ} \mathrm{C}$ will be less than that of washed $\mathrm{HCP}$ items (nominal $1 \mathrm{wt} \%$ salt) processed at $1000^{\circ} \mathrm{C}$. 
Table 3.7. Cycle 13 Scrubber Water Chloride Balance

\begin{tabular}{|c|c|}
\hline Source of Chloride & Chloride, $\mathrm{g}$ \\
\hline Simulant Charge & 9.02 \\
\hline Acid Derived Chloride in Scrubber & 2.13 \\
\hline Total Measured in Scrubber (ISE) & 3.15 \\
\hline \multicolumn{2}{|c|}{ Sources for Chloride in Scrubber } \\
\hline $\begin{array}{l}\text { Derived from } \mathrm{MgCl}_{2} \\
\text { (assuming all } 100 \% \mathrm{MgCl}_{2} \\
\text { decomposition to form } \mathrm{HCl} \text { and } \mathrm{MgO} \text { ) }\end{array}$ & 1.64 \\
\hline Derived from $\mathrm{NaCl}$ & 0.31 \\
\hline Derived from $\mathrm{KCl}$ & 0.22 \\
\hline Derived from $\mathrm{FeCl}_{3}$ & 0.12 \\
\hline Derived from $\mathrm{CrCl}_{3}$ & 0.04 \\
\hline Total from derived sources & 2.33 \\
\hline $\begin{array}{l}\text { Balance (Measured - Chloride derived } \\
\text { from source) }\end{array}$ & 0.82 \\
\hline
\end{tabular}

\subsection{Analysis of Filter and Filter Housing Solids}

\subsubsection{Filter Solids After Cycle 52}

A total of $0.80 \mathrm{~g}$ of salt precipitate was collected on the 5- $\mu \mathrm{m}$ filter after Cycles 51 and 52. A 0.02-g sample of these solids was removed from the filter surface after Cycle 52 and dissolved and analyzed via ICP. Na and K account for $98.1 \%$ of all the cations measured (Table 3.8). A stoichiometric balance for chloride (assuming $\mathrm{Na}$ and $\mathrm{K}$ exist as chloride salt) accounts for $97.7 \%$ of the total sample mass, which suggests that $\mathrm{NaCl}$ and $\mathrm{KCl}$ are the predominant constituents in these filter solids. Consistent with the higher vapor pressure of $\mathrm{KCl}$ relative to $\mathrm{NaCl}$, the mole ratio of $\mathrm{K}: \mathrm{Na}$ was found to be 1.53:1.0.

Table 3.8. Composition of Filter Solids After Cycle 52

\begin{tabular}{|c|c|}
\hline Analyte & Concentration, $\mathbf{g} / \mathbf{g}$ \\
\hline $\mathrm{Cr}$ & 0.006 \\
\hline $\mathrm{Cu}$ & 0.001 \\
\hline $\mathrm{K}$ & 0.339 \\
\hline $\mathrm{Na}$ & 0.130 \\
\hline $\mathrm{Si}$ & 0.002 \\
\hline $\mathrm{Zn}$ & 0.001 \\
\hline Total Cations & 0.479 \\
\hline $\begin{array}{l}\text { Stoichiometric } \\
\text { Chloride }(\mathrm{NaCl}, \mathrm{KCl})\end{array}$ & 0.509 \\
\hline
\end{tabular}

\subsubsection{Material from Filter Housing After Cycle 53 and Leached Filter After Cycle 54}

After Cycles 53 and 54, a green crystalline deposit was found at the bottom of the filter housing (Figure 3.2). The appearance of the deposit suggests that the material was in a molten state before system 


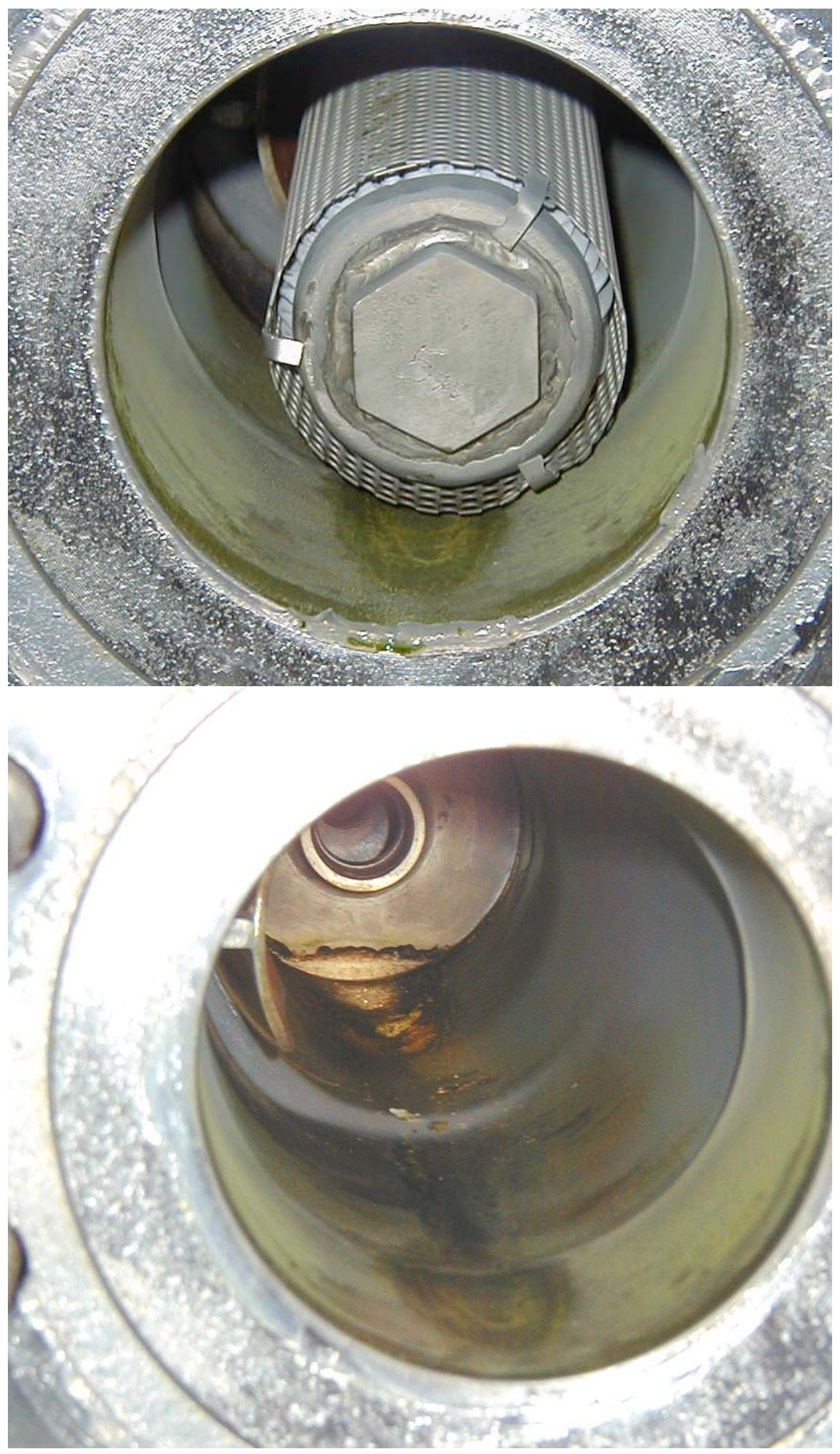

Figure 3.2. Deposits Inside Filter Housing After Cycle 53 
cooldown. The mass of the deposit (after each cycle) was estimated to be from 2 to $4 \mathrm{~g}$. A $1.25-\mathrm{g}$ sample was collected after Cycle 53 and leached and analyzed (Table 3.9). Na and $\mathrm{K}$ account for about $46 \%$ of the cations; $\mathrm{Fe}, \mathrm{Cr}$, and $\mathrm{Ni}$ account for another $51 \%$. The total of the cations and chloride measured with the ISE probe accounts for $78 \%$ of the sample mass, and insoluble residues account for another $1 \%$. Table 3.9 lists the mass of water, associated as waters of hydration, with $\mathrm{FeCl}_{2} \cdot 4 \mathrm{H}_{2} \mathrm{O}$ and $\mathrm{NiCl}_{2} \cdot 6 \mathrm{H}_{2} \mathrm{O}$. Adding the assumed mass of the waters of hydration to the total accounts for $98 \%$ of the sample mass. The chloride associated with $\mathrm{HCl}$ based on the $\mathrm{pH}$ of the sample is very small relative to the total chloride concentration. Before starting Cycle 54, the filter housing was cleaned. After Cycle 54, the green crystalline deposit was sampled and analyzed by XRD (Section 3.4). Most of the material was identified as iron chloride compounds. One minor phase containing $\mathrm{K}$ was identified, but no Na phases were found.

After Cycles 53 and 54, the filter element showed appreciable mass gain; however, solids deposits on the filter were not seen by visual inspection (Figure 3.3). The appearance of this filter differed greatly from that of loaded filters from the $1000^{\circ} \mathrm{C}$ testing (Figure 3.4). To locate the accumulated mass on the filter,

Table 3.9. Composition of Material from Filter Housing After Cycle 53 and Leached Filter After Cycle 54

\begin{tabular}{|c|c|c|c|c|}
\hline \multirow[b]{2}{*}{ Analyte } & \multicolumn{2}{|c|}{$\begin{array}{c}\text { Material Collected from Filter } \\
\text { Housing After Cycle } 53\end{array}$} & \multicolumn{2}{|c|}{$\begin{array}{c}\text { Solids Leached from Filter Material } \\
\text { After Cycle } 54\end{array}$} \\
\hline & $\begin{array}{c}\text { Leachate Solution } \\
\text { Concentration, mg/L }\end{array}$ & $\begin{array}{c}\text { Solids } \\
\text { Fraction, } \\
\mathbf{g} / \mathbf{g} \\
\end{array}$ & $\begin{array}{c}\text { Leachate Solution } \\
\text { Concentration, mg/L }\end{array}$ & $\begin{array}{l}\text { Solids } \\
\text { Fraction, g/g }\end{array}$ \\
\hline $\mathrm{Al}$ & 3.449 & 0.0003 & $<\operatorname{det}$ & $<$ det \\
\hline $\mathrm{Bi}$ & 1.101 & 0.0001 & $<$ det & $<$ det \\
\hline $\mathrm{Ca}$ & 1.650 & 0.0001 & 1.234 & 0.0003 \\
\hline $\mathrm{Co}$ & 4.461 & 0.0004 & 3.042 & 0.0008 \\
\hline $\mathrm{Cr}$ & 447.3 & 0.0356 & 168.2 & 0.0428 \\
\hline $\mathrm{Cu}$ & 12.89 & 0.0010 & 7.358 & 0.0019 \\
\hline $\mathrm{Eu}$ & 2.681 & 0.0002 & 1.257 & 0.0003 \\
\hline $\mathrm{Fe}$ & 1605 & 0.1279 & 779.7 & 0.1982 \\
\hline $\mathrm{K}$ & 1454 & 0.1159 & 118.1 & 0.0300 \\
\hline $\mathrm{Mn}$ & 40.69 & 0.0032 & 13.55 & 0.0034 \\
\hline Mo & 59.46 & 0.0047 & 18.62 & 0.0047 \\
\hline $\mathrm{Na}$ & 591.3 & 0.0471 & 46.73 & 0.0119 \\
\hline $\mathrm{Ni}$ & 192.1 & 0.0153 & 128.7 & 0.0327 \\
\hline $\mathrm{Si}$ & $\begin{array}{l}- \\
-\end{array}$ & -- & 1.194 & 0.0003 \\
\hline Total Cations & 4416 & 0.3519 & -- & 0.3274 \\
\hline Chloride (ISE) & 5388 & 0.4294 & 1354 & 0.3443 \\
\hline $\mathrm{pH}$ & 2.25 & -- & 3.14 & -- \\
\hline Acid Derived Chloride & 199.3 & -- & 25.7 & -- \\
\hline Insoluble Residue, g/g & -- & 0.0094 & -- & 0.0102 \\
\hline $\begin{array}{l}\text { Waters of Hydration } \\
\left(\mathrm{FeCl}_{2} \cdot 4 \mathrm{H}_{2} \mathrm{O} \text {, }\right. \\
\left.\mathrm{NiCl}_{2} \cdot 6 \mathrm{H}_{2} \mathrm{O}\right), \mathrm{g} / \mathrm{g}\end{array}$ & -- & 0.1930 & -- & 0.3157 \\
\hline
\end{tabular}




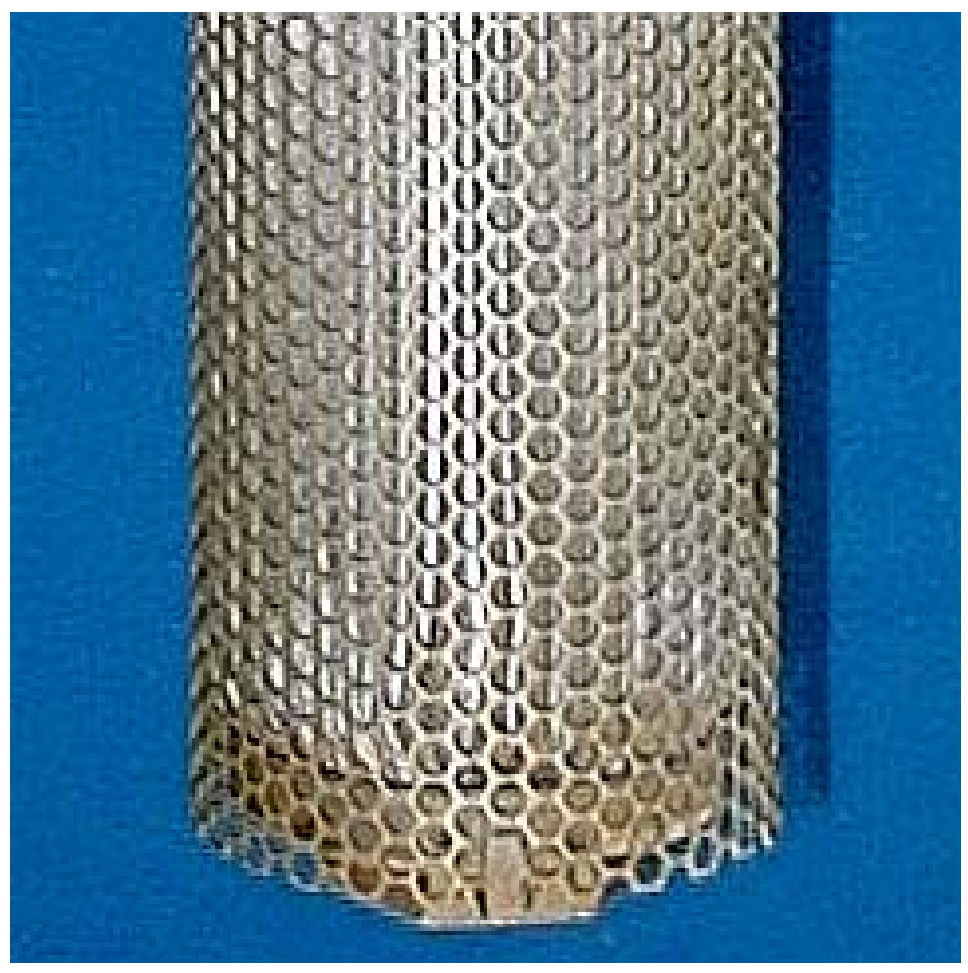

Figure 3.3. Condition of 5- $\mu \mathrm{m}$ Rosedale Pleated Metal Filter Element After Cycle 54 (i.e., four test cycles)

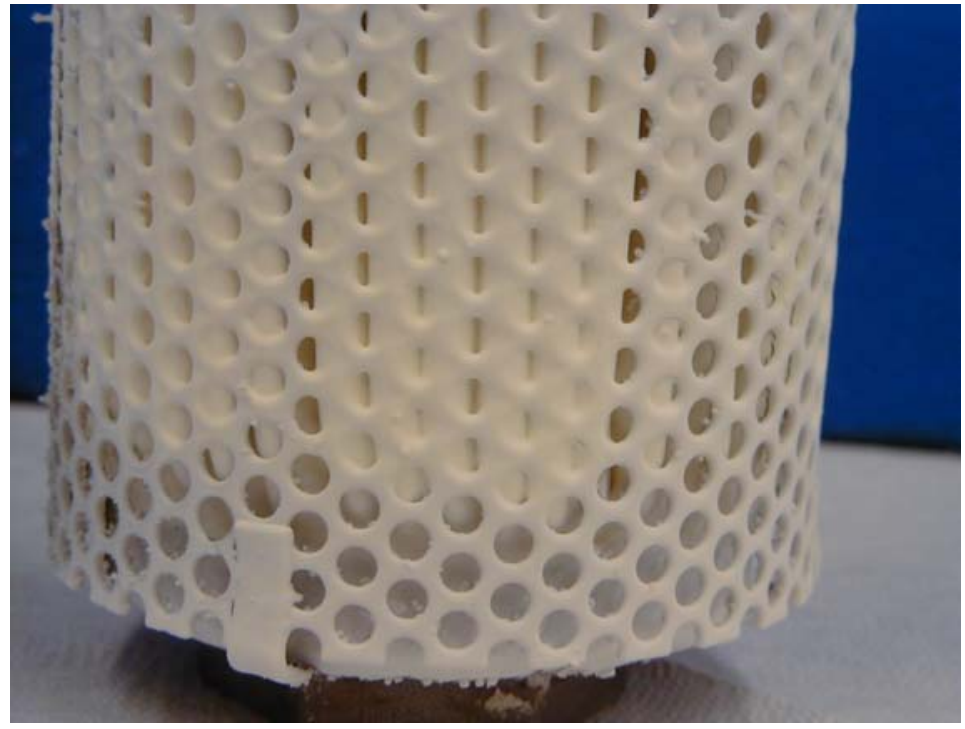

Figure 3.4. Salt Deposits on Outer Shell (pleated protector) of $20-\mu \mathrm{m}$ Rosedale Pleated Metal Filter Cartridge After Five Test Cycles of Processing $1 \mathrm{wt} \%$ Chloride Salt at $1000^{\circ} \mathrm{C}$ (Fischer et al. 2002) 
after Cycle 54, a 9-in. ${ }^{2}$ patch was removed from the filter and leached in water. Water leaching removed $0.4722 \mathrm{~g}$ of material from the 9 -in. ${ }^{2}$ patch of the pleated stainless steel filter. The analytical results given in Table 3.9 show that $\mathrm{Fe}, \mathrm{Cr}$, and $\mathrm{Ni}$ account for nearly $84 \%$ of the cation analytes. $\mathrm{Na}$ and $\mathrm{K}$ account for another $13 \%$ of the cations leached from the sample. The total mass of cations and chloride measured using the ISE probe accounts for $67 \%$ of the sample weight, and the insoluble solids residue accounts for another $2 \%$. The balance of the mass is attributed to waters of hydration associated with the leached Ni and $\mathrm{Fe}$, which are presumed to be present as hydrated chloride compounds. This presumption is supported by XRD data (Section 3.1.4). The Fe and Ni present in the filter leachate most likely originated as corrosion products formed in the boat. Close inspection of the leached filter patch showed no indications of the filter media corroding.

Table 3.9 also provides the expected weight of water that would be included in the sample, based on the presence of $\mathrm{FeCl}_{2} \cdot 4 \mathrm{H}_{2} \mathrm{O}$ and $\mathrm{NiCl}_{2} \cdot 6 \mathrm{H}_{2} \mathrm{O}$. Adding this water mass to the total measured mass of individual analytes (using the ISE value for chloride) and the insoluble residue accounts for $100 \%$ of the sample mass. The $\mathrm{pH}$ of the leachate and the corresponding quantity of chloride that would be associated with $\mathrm{HCl}$ in the solution are also given in Table 3.9. It can be seen that $\mathrm{HCl}$ contributes very little to the chloride inventory of this sample.

\subsection{Results from X-ray Diffraction (XRD) Analysis}

Seven samples from Cycles 51 through 54 were submitted for phase identification analysis by XRD. The results are presented in Table 3.10. The X-ray patterns from these analyses are provided in Appendix B. In addition to phase identification, a semi-quantitative analysis on the relative abundance of the various phases is provided. The phases listed in Table 3.10 were positively identified, unless indicated otherwise. Potassium and sodium chloride binary salts were identified in many of samples, and the approximate sodium content was estimated. The only cerium phase found in the samples was $\mathrm{CeO}_{2}$, suggesting the $\mathrm{CeO}_{2}$ in the simulant did not react during the testing.

Samples from the crucible and boat (Tan Layer) from Cycle 52 were found to contain only $\mathrm{CeO}_{2}$ and $\mathrm{NaCl}$ and $\mathrm{KCl}$ salts and binary salts. The various layers in the calcined simulant are shown in Figure 3.5. While this figure shows material from Cycle 51, both Cycles 51 and Cycle 52 were conducted under the same conditions, and the calcined materials appeared the same.

In addition to $\mathrm{CeO}_{2}, \mathrm{NaCl}$ and $\mathrm{KCl}$ salts, and binary salts, the crucible sample from Cycle 54 contained $\mathrm{MgO}$ (probable) and $\mathrm{MgFe}_{2} \mathrm{O}_{4}$ (tentative). While no $\mathrm{MgCl}_{2}$ was identified in this sample by XRD, chemical analysis of the crucible sample from Cycle 53 (Cycles 53 and 54 were duplicate runs) indicated that some $\mathrm{MgCl}_{2}$ was still present in the crucible after calcination. The tentative identification of $\mathrm{MgFe}_{2} \mathrm{O}_{4}$ indicated that coupon and boat corrosion products migrated to the crucible.

$\mathrm{MgCl}_{2}$ was tentatively identified in the Tan Layer (material in which corrosion products diffused into and discolored the simulant) from the boat after Cycle 54. In addition to the $\mathrm{CeO}_{2}$ and $\mathrm{NaCl}$ and $\mathrm{KCl}$ salts, $\mathrm{NiO}$ was identified. The material collected immediately adjacent to the bottom and wall of the boat (Cycle 54, Dark Layer) contained an appreciable quantity of $\mathrm{MgCr}_{2} \mathrm{O}_{4}(15 \%$ relative abundance). The presence of this phase indicates $\mathrm{MgCl}_{2}$ is interacting with the boat material (Hastelloy $\mathrm{X}$ ). Other boat corrosion products were also observed $\left(\mathrm{NiO}\right.$ and $\left.\mathrm{Cr}_{2} \mathrm{O}_{3}\right)$. Figure 3.6 shows the various layers in the calcined simulant after Cycle 53. 
Table 3.10. Results from X-ray Diffraction Analyses

\begin{tabular}{|c|c|c|}
\hline Sample & Phases & $\begin{array}{c}\text { Relative } \\
\text { Abundance, } \\
\text { Weight \% } \\
\end{array}$ \\
\hline $\begin{array}{l}\text { Cycle 52 } \\
\text { Crucible Sample }\end{array}$ & $\begin{array}{l}\text { Cerianite, } \mathrm{CeO}_{2} \\
\text { Sylvite, } \mathrm{KCl} \\
\text { Sylvite }[\mathrm{Solid} \text { Solution/Binary Salt, } \mathrm{Na} \sim 0.1]^{\text {(a) }} \\
\text { Halite, } \mathrm{NaCl} \\
\text { Halite [Solid Solution/Binary Salt, } \mathrm{Na} \sim 0.9]^{\text {(a) }}\end{array}$ & $\begin{array}{l}\sim 80 \\
\sim 10 \\
<5 \\
<5 \\
<5\end{array}$ \\
\hline $\begin{array}{l}\text { Cycle } 52 \\
\text { Tan Layer }(40 \% \\
\text { to } 60 \% \text { of boat } \\
\text { contents })\end{array}$ & $\begin{array}{l}\text { Cerianite, } \mathrm{CeO}_{2} \\
\text { Sylvite, } \mathrm{KCl} \\
\text { Halite, } \mathrm{NaCl} \\
\text { Halite [Solid Solution/Binary Salt, } \mathrm{Na} \sim 0.9]^{(\mathrm{a})}\end{array}$ & $\begin{array}{l}\sim 85 \\
\sim 10 \\
<5 \\
<5\end{array}$ \\
\hline $\begin{array}{l}\text { Cycle } 54 \\
\text { Crucible Sample }\end{array}$ & $\begin{array}{l}\text { Cerianite, } \mathrm{CeO}_{2} \\
\text { Sylvite, } \mathrm{KCl} \\
\text { Sylvite [Solid Solution/Binary Salt, } \mathrm{Na} \sim 0.1]^{(\mathrm{a})} \\
\text { Halite [Solid Solution/Binary Salt, } \mathrm{Na} \sim 0.9]^{(\mathrm{a})} \\
\text { Periclase, } \mathrm{MgO} \text { (Probable ID) } \\
\text { Magnesioferrite, } \mathrm{MgFe}_{2} \mathrm{O}_{4} \text { (Tentative ID) }\end{array}$ & $\begin{array}{l}\sim 90 \\
<5 \\
<5 \\
<5 \\
<1 \\
<1\end{array}$ \\
\hline $\begin{array}{l}\text { Cycle } 54 \\
\text { Tan Layer }(40 \% \\
\text { to } 60 \% \text { of boat } \\
\text { contents) }\end{array}$ & $\begin{array}{l}\text { Cerianite, } \mathrm{CeO}_{2} \\
\text { Sylvite, } \mathrm{KCl} \\
\text { Halite [Solid Solution/Binary Salt, } \mathrm{Na} \sim 0.9 \text { ] }^{(\mathrm{a})} \\
\text { Bunsenite, } \mathrm{NiO} \text { (Probable ID) } \\
\text { Magnesiochromite, } \mathrm{MgCr}_{2} \mathrm{O}_{4} \text { (Tentative ID) } \\
\text { Chloromagnesite, } \mathrm{MgCl}_{2} \text { (Tentative ID) }\end{array}$ & $\begin{array}{l}\sim 90 \\
<5 \\
<5 \\
<5 \\
<1 \\
<1\end{array}$ \\
\hline $\begin{array}{l}\text { Cycle } 54 \\
\text { Bottom Layer } \\
\text { (5\% to } 10 \% \text { of } \\
\text { boat contents) }\end{array}$ & $\begin{array}{l}\text { Cerianite, } \mathrm{CeO}_{2} \\
\text { Sylvite, } \mathrm{KCl} \\
\text { Halite [Solid Solution/Binary Salt, } \mathrm{Na} \sim 0.9]^{\text {(a) }} \\
\text { Bunsenite, } \mathrm{NiO} \\
\text { Magnesiochromite, } \mathrm{MgCr}_{2} \mathrm{O}_{4} \\
\text { Eskolaite, } \mathrm{Cr}_{2} \mathrm{O}_{3} \\
\text { Two weak peaks could not be identified }\end{array}$ & $\begin{array}{l}\sim 60 \\
<10 \\
<5 \\
<10 \\
\sim 15 \\
<5\end{array}$ \\
\hline $\begin{array}{l}\text { Cycle } 54 \\
\text { Scrapings from } \\
\text { Filter Element }\end{array}$ & $\begin{array}{l}\text { Sylvite, } \mathrm{KCl} \\
\text { Halite, } \mathrm{NaCl} \\
\text { Erythrosiderite, } \mathrm{K}_{2} \mathrm{FeCl}_{5} \cdot \mathrm{H}_{2} \mathrm{O} \text { (Tentative ID) } \\
\text { Rinneite, } \mathrm{K}_{3} \mathrm{NaFeCl}_{6}\left(\mathrm{Tentative} \mathrm{ID)} \mathrm{Hen} \text { Hydromolisite, } \mathrm{FeCl}_{3} \cdot \mathrm{H}_{2} \mathrm{O} \text { (Tentative ID) }\right. \\
\text { Bischofite, } \mathrm{MgCl}_{2}\left(\mathrm{H}_{2} \mathrm{O}\right)_{6} \text { (Tentative ID) } \\
\text { Several weak peaks could not be identified }\end{array}$ & $\begin{array}{l}\sim 60 \\
\sim 40\end{array}$ \\
\hline $\begin{array}{l}\text { Material from } \\
\text { Filter Housing, } \\
\text { Cycle } 54\end{array}$ & $\begin{array}{l}\mathrm{FeCl}_{2} \cdot 4 \mathrm{H}_{2} \mathrm{O} \\
\text { Erythrosiderite, } \mathrm{K}_{2} \mathrm{FeCl}_{5} \cdot \mathrm{H}_{2} \mathrm{O} \\
\text { Hydromolisite, } \mathrm{FeCl}_{3} \cdot \mathrm{H}_{2} \mathrm{O}\end{array}$ & $\begin{array}{l}\sim 85 \\
\sim 10 \\
\sim 5\end{array}$ \\
\hline
\end{tabular}




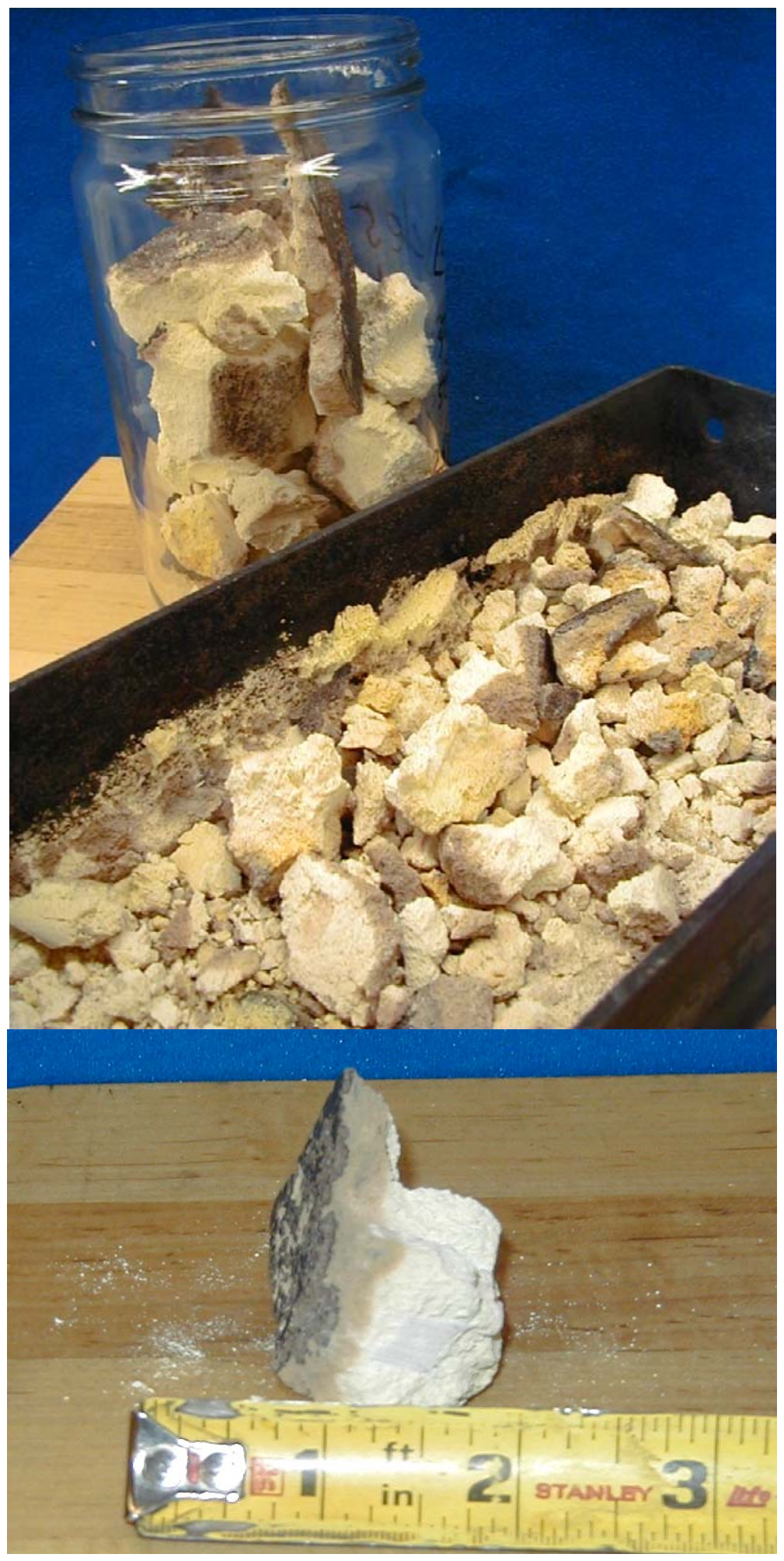

Figure 3.5. Crumbled Calcined Material from Cycle 51 


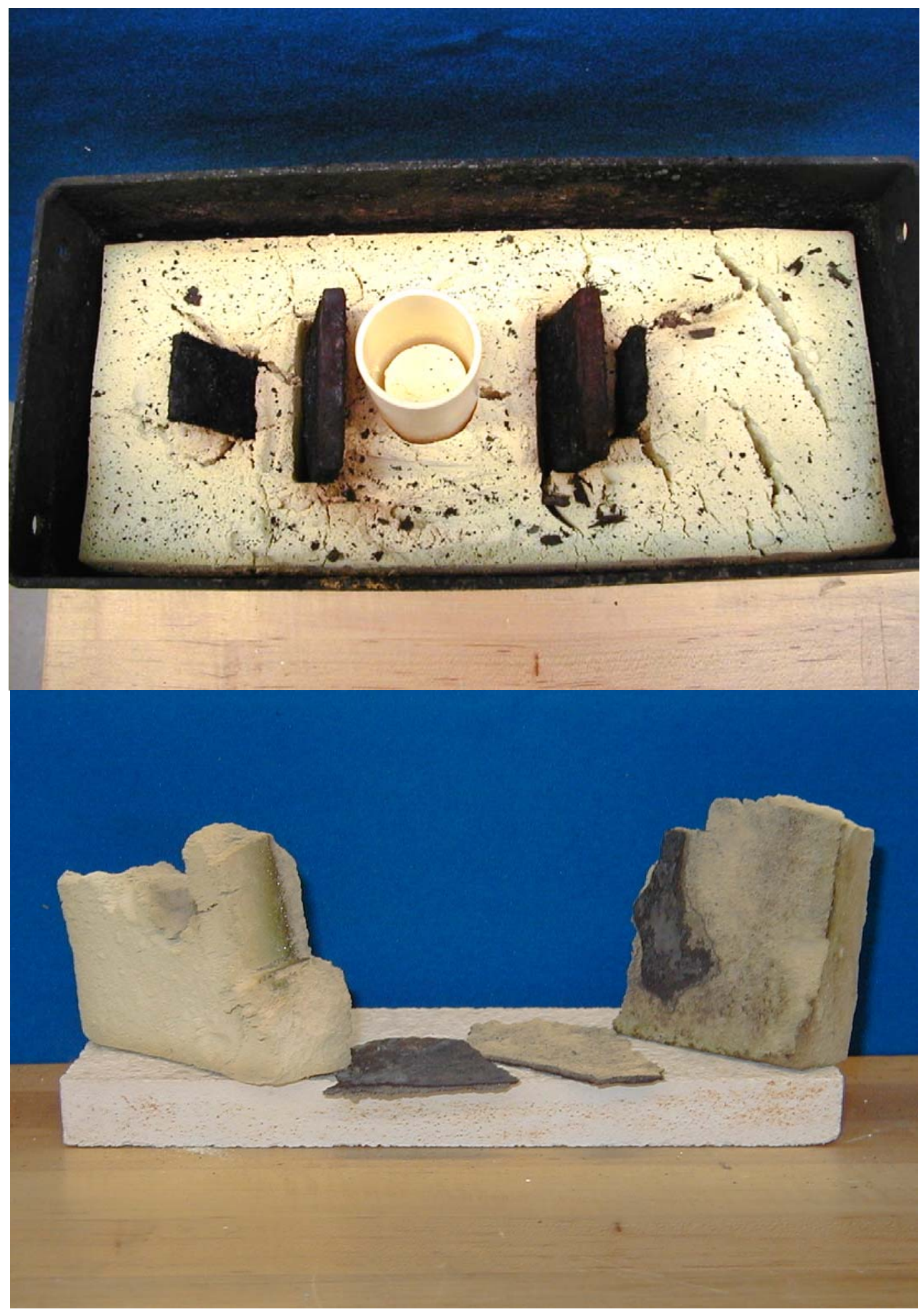

Figure 3.6. Calcined Material After Cycle 53 (Cycles 53 and 54 were run under duplicate conditions.) 
The material scraped from the filter element surface after Cycle 54 was composed primarily of $\mathrm{KCl}$ and $\mathrm{NaCl}$. These salts may have been deposited from Cycles 51 and 52, since the same filter was used for all runs. The minor phases tentatively identified in this sample are consistent with the composition of the material collected from the filter housing.

The material collected from the filter housing after Cycle 54 (a green crystalline deposit, Figure 3.2) was found to consist of various iron chloride compounds $\left(\mathrm{FeCl}_{2} \cdot 4 \mathrm{H}_{2} \mathrm{O}, \mathrm{K}_{2} \mathrm{FeCl}_{5} \cdot \mathrm{H}_{2} \mathrm{O}\right.$, and $\left.\mathrm{FeCl}_{3} \cdot \mathrm{H}_{2} \mathrm{O}\right)$. After Cycle 54, the filter housing was thoroughly cleaned and inspected, and the electro-polished surface showed no evidence of corrosive attack. Based on this observation, the iron chloride compounds most likely originated within the simulant and boat.

\subsection{Material Performance Testing}

Material performance testing was conducted by observing the appearance and weight change of system components (boat, air baffle, offgas lines, filter element) and metal coupons. After each cycle, the boat, air baffle, and coupons were cleaned (nylon brush and water washing) and weighed.

\subsubsection{System Components}

Weight change data on system components are provided in Table 3.11. During Cycles 51 and 52, the loaded boat (Boat + Simulant + Coupons + Crucible) gained 6 to $7 \mathrm{~g}$ [see Figure 3.1, which shows the loaded boat (simulant, coupons and crucible) before and after Cycle 51]. For these tests, the weight gain associated with oxidation of the boat and coupons more than offset the weight loss resulting from chloride salt volatilization/decomposition. In Cycles 53 and 54, the loaded boat (Boat + Simulant + Coupons + Crucible) lost 38 to $42 \mathrm{~g}$. Most of this weight loss can be attributed to the removal of the waters of hydration associated with the $\mathrm{MgCl}_{2} \cdot 6 \mathrm{H}_{2} \mathrm{O}(\sim 62 \mathrm{~g})$.

Table 3.11. System Component Weight Data

\begin{tabular}{|c|c|c|c|c|}
\hline \multirow[b]{3}{*}{ System Component } & \multicolumn{4}{|c|}{ Weight Change, $g$} \\
\hline & \multicolumn{2}{|c|}{$\mathrm{NaCl} / \mathrm{KCl}$ Simulant } & \multicolumn{2}{|c|}{$\begin{array}{l}\mathrm{NaCl} / \mathrm{KCl} / \mathrm{MgCl}_{2} \\
\text { Simulant }\end{array}$} \\
\hline & Cycle 51 & Cycle 52 & Cycle 53 & Cycle 54 \\
\hline $\begin{array}{l}\text { Boat }+ \text { Simulant }+ \text { Coupons } \\
+ \text { Crucible, } g\end{array}$ & +6 & +7 & -42 & -38 \\
\hline Hastelloy X Boat, g & -27 & -11 & -112 & -85 \\
\hline HR-160, Air Baffle, g & 0.0 & +0.05 & -0.42 & -0.10 \\
\hline $\begin{array}{l}\text { Internal Offgas Line, } \mathrm{g} \\
\text { [Corrosion products } \\
\text { removed, }{ }^{(\mathrm{a})} \mathrm{g} \text { ] }\end{array}$ & $\begin{array}{c}+0.15 \\
{[0]}\end{array}$ & $\begin{array}{c}+0.24 \\
{[0]}\end{array}$ & $\begin{array}{c}+0.55 \\
{[0.44]}\end{array}$ & $\begin{array}{l}+0.39 \\
{[0.79]}\end{array}$ \\
\hline External Offgas Line, g & 0.0 & +0.26 & +0.24 & +0.15 \\
\hline Filter Element, $\mathrm{g}$ & +0.4 & +0.4 & +5.98 & +7.18 \\
\hline $\begin{array}{l}\text { Waters of hydration in } \\
\text { simulant feed, } g\end{array}$ & 0 & 0 & 61.8 & 61.8 \\
\hline \multicolumn{5}{|c|}{$\begin{array}{l}\text { (a) After the internal offgas line was weighed, the line was tapped, and loose } \\
\text { corrosion products were removed and weighed. }\end{array}$} \\
\hline
\end{tabular}


The mass losses to the Hastelloy X boat during Cycles 51 and 52 (27 g and $11 \mathrm{~g}$, respectively) are similar to the 12 to $25 \mathrm{~g} /$ cycle weight losses observed in the testing conducted with 16 to $20 \mathrm{~g}$ chloride salt at $1000^{\circ} \mathrm{C}$. However, with the addition of $\mathrm{MgCl}_{2}$ in Cycles 53 and 54, the Hastelloy $\mathrm{X}$ boat experienced very severe corrosive attack, with weight losses to the boat of $112 \mathrm{~g}$ and $85 \mathrm{~g}$, respectively.

Corrosion to the Haynes HR-160 air baffle, the Inconel 690 internal offgas line, the Inconel 600 external offgas line, the filter, and the filter housing was minimal during Cycles 51 through 54. After Cycles 53 and 54, small quantities of loose corrosion products were removed from the internal offgas line and weighed. Weight gains measured on the filter element were the result of particulate material that collected on the filter.

\subsubsection{Metal Coupons}

The performance of RA602CA and Inconel 690 (mill finish plate) was examined by placing metal coupons in the boat, half submerged in the simulant. RA602CA is the material of construction of the retort system in the PFP SPE furnaces. Inconel 690 was found to be one of the better performing materials during the testing conducted with $1 \mathrm{wt} \%$ chloride salt at $1000^{\circ} \mathrm{C}$. Therefore, it was included in this testing to provide an indication of the relative severity of the corrosion environments. Figures 3.7 through 3.10 show the initial and corroded conditions of the metal coupons.

For Cycle 54, two additional RA602CA coupons, provided by PFP, were included in the test (Figure 3.9). These coupons, which included several welds, were heat treated at $1000^{\circ} \mathrm{C}$ for $3.75 \mathrm{hr}$ to form a protective oxide coating before Cycle 54 was run.

The corrosion rates, expressed as mg-loss $/ \mathrm{cm}^{2}$ initial surface area, per cycle are provided in Table 3.12. During Cycles 51 and $52\left(20 \mathrm{wt} \% \mathrm{NaCl} / \mathrm{KCl}\right.$ at $\left.750^{\circ} \mathrm{C}\right)$, the corrosion rates were similar to those measured during the tests with $1 \mathrm{wt} \%$ salt at $1000^{\circ} \mathrm{C}$. With $16 \mathrm{~g}$ chloride salt per charge and a 2-hr hold at $1000^{\circ} \mathrm{C}$, two Inconel 690 coupons exhibited corrosion rates of 20.8 and $26.5 \mathrm{mg} / \mathrm{cm}^{2}$ per cycle (average rates from 19 cycles). During Cycles 53 and $54\left(20 \mathrm{wt} \% \mathrm{NaCl} / \mathrm{KCl} / \mathrm{and} \mathrm{MgCl}_{2}\right.$ at $\left.750^{\circ} \mathrm{C}\right)$, significantly higher corrosion rates were observed. This trend is consistent with the boat weight loss data given in Table 3.11. The presence of the $\mathrm{MgCl}_{2}$, some fraction of which likely decomposes to $\mathrm{MgO}$ and $\mathrm{HCl}$, greatly increases the severity of the corrosion. From the data in Table 3.12, it is unclear whether the heat treatment improved the corrosion resistance of coupons RA602CA-E and RA602CA-A. While the corrosion rates are lower for the heat-treated coupons, the actual surface areas of coupons RA602CA-1 and -2 were likely much greater as the result of the corrosion experienced during Cycles 51 through 53 (visually, the surfaces of RA602CA-1 and -2 were rough after Cycle 53). 


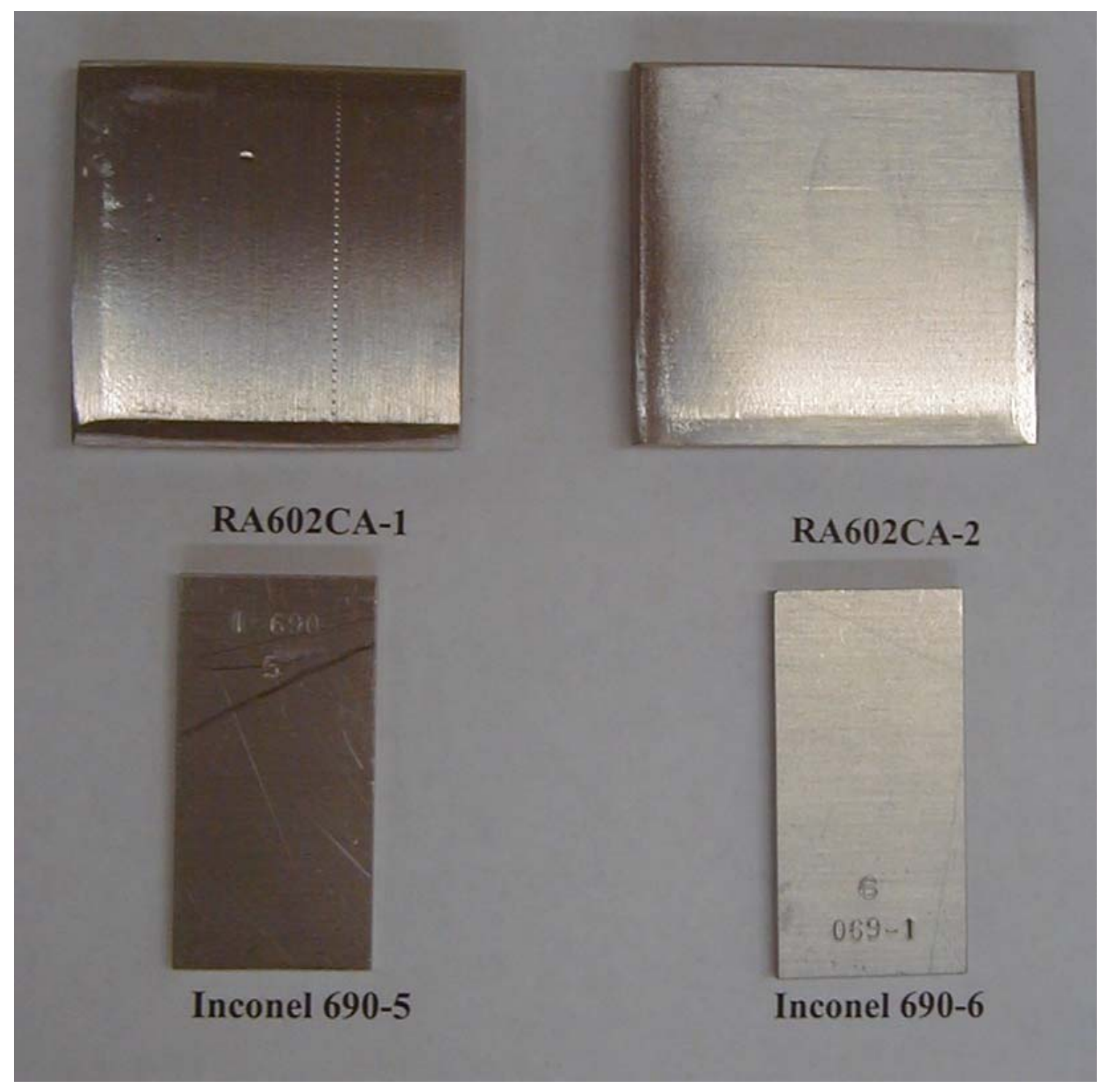

Figure 3.7. Initial Condition of RA602CA and Inconel 690 Metal Coupons 

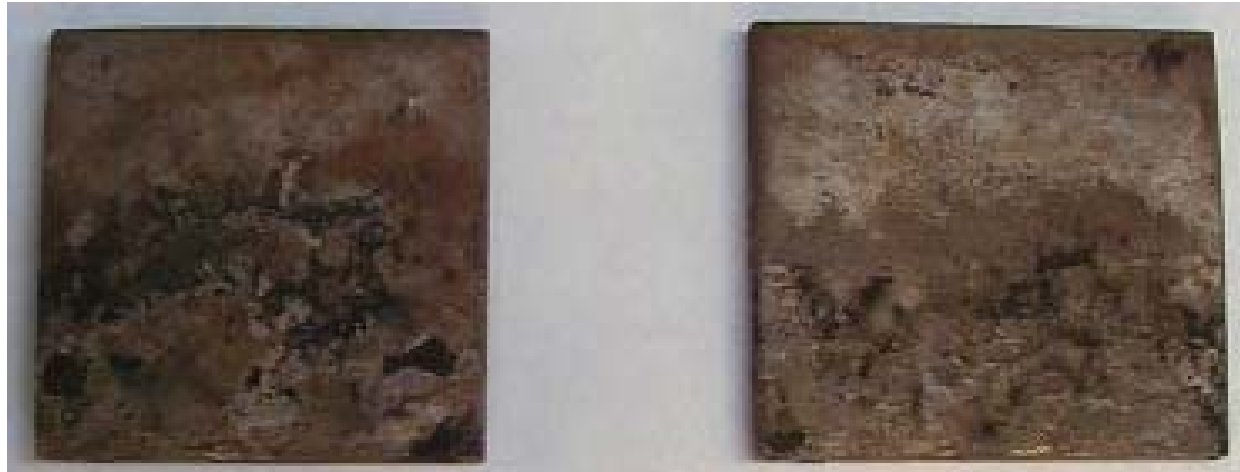

RA602CA-1

RA602CA-2
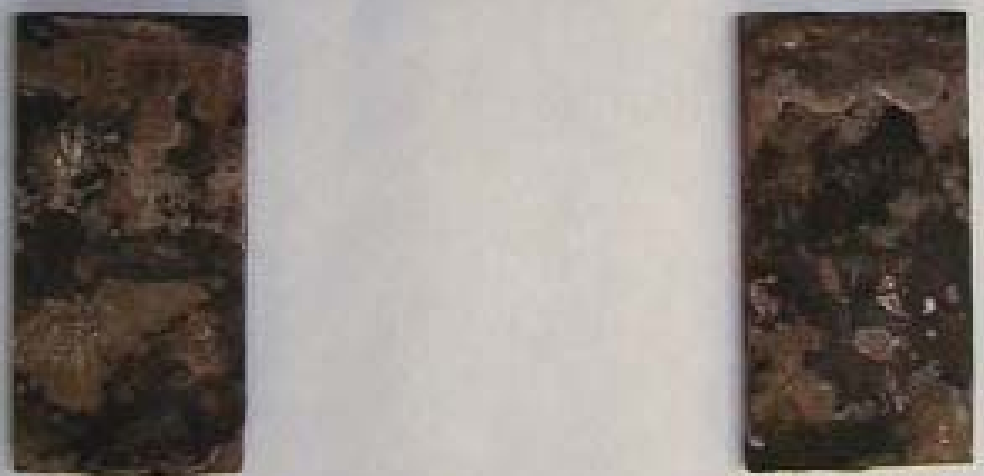

Inconel 690-5

Inconel 690-6

Figure 3.8. RA602CA and Inconel 690 Metal Coupons After Cycles 51 and 52. Coupons were partially submerged in simulants.

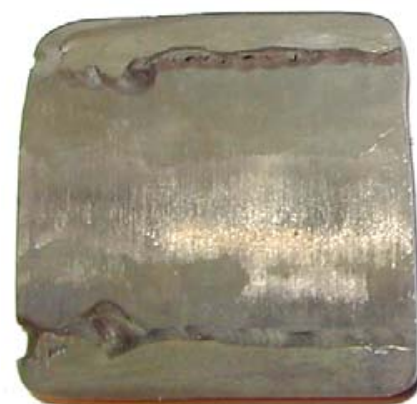

RA602CA-E

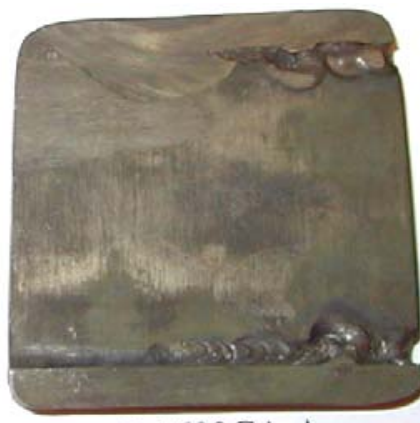

RA602CA-A

Figure 3.9. Initial Condition of Heat-Treated RA602CA Coupons 


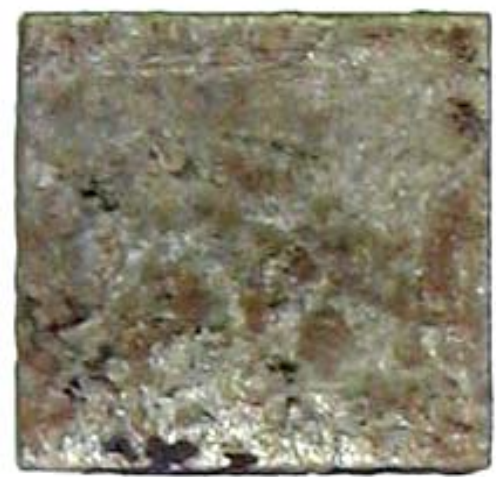

RA602C A-1

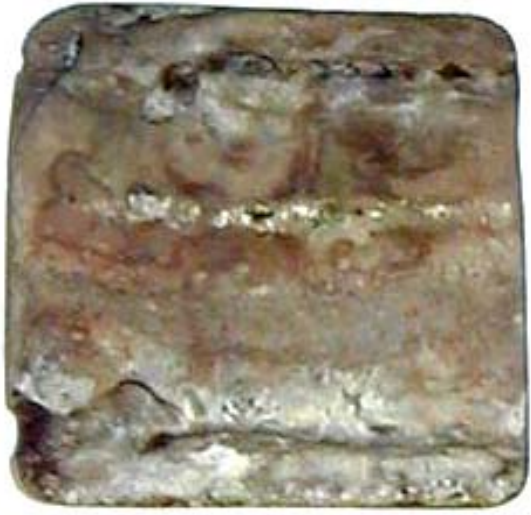

RA602CA-E

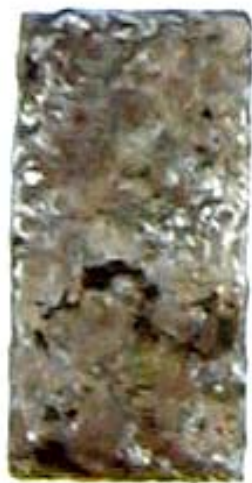

Inconel 690-5

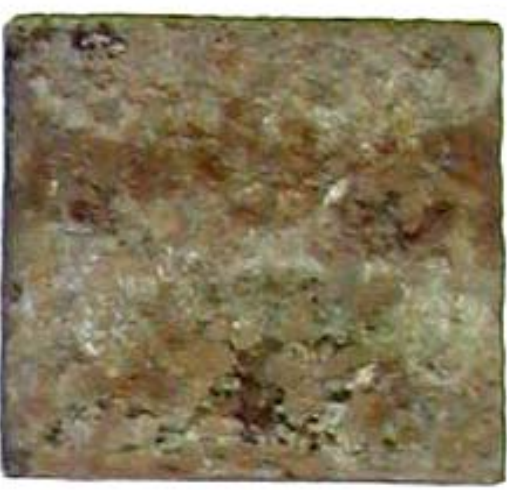

R: $1602 \mathrm{C}:-2$

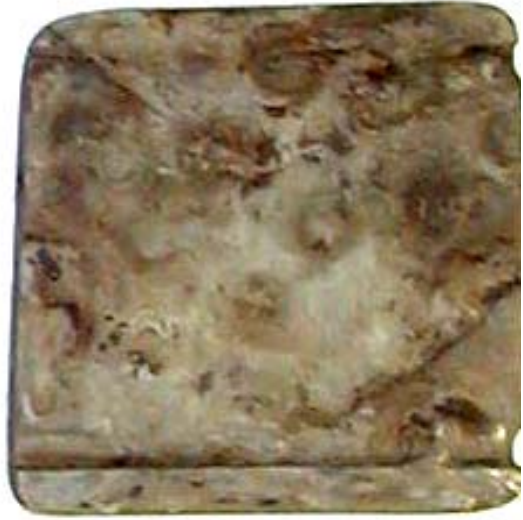

RA602CA-A

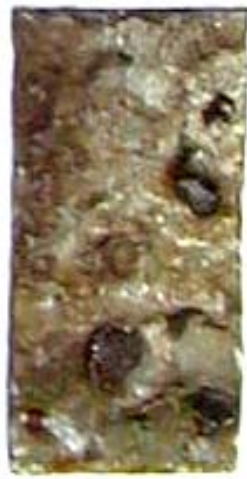

Incomel 690-6

Figure 3.10. RA602CA and Inconel 690 Metal Coupons After Cycle 54 Coupons Were Partially Submerged in Simulant 
Table 3.12. Coupon Corrosion Rates During Cycles 51 Through 54

\begin{tabular}{|c|c|c|c|c|}
\hline \multirow[b]{3}{*}{ Coupon ID } & \multicolumn{4}{|c|}{ Corrosion rate, $\mathrm{mg} / \mathrm{cm}^{2}$ per cycle } \\
\hline & \multicolumn{2}{|c|}{ NaCl/KCl Simulant } & \multicolumn{2}{|c|}{$\begin{array}{c}\mathrm{NaCl} / \mathrm{KCl} / \mathrm{MgCl}_{2} \\
\text { Simulant }\end{array}$} \\
\hline & Cycle 51 & Cycle 52 & Cycle 53 & Cycle 54 \\
\hline RA602CA-1 & 14.0 & 33.7 & 83.8 & 91.5 \\
\hline RA602CA-2 & 10.0 & 35.3 & 74.8 & 92.3 \\
\hline RA602CA-E $^{(a)}$ & \multirow{2}{*}{\multicolumn{3}{|c|}{$\begin{array}{l}\text { Not tested } \\
\text { Not tested }\end{array}$}} & 54.5 \\
\hline RA602CA-A $^{(a)}$ & & & & 40.9 \\
\hline Inconel 690-5 & 32.6 & 33.0 & 128 & 149 \\
\hline Inconel 690-6 & 38.0 & 42.8 & 126 & 143 \\
\hline
\end{tabular}

(a) RA602CA-E and RA602CA-A heat treated at $1000^{\circ} \mathrm{C}$ for $3.75 \mathrm{hr}$ before Cycle 54.

\subsection{System Operability Observations}

\subsubsection{Furnace Temperature Profile}

Temperatures were monitored during Cycles 51 through 54 in the furnace chamber (control thermocouple) and in the boat. The control thermocouple protrudes several inches through the back wall of the furnace chamber and is located about $1 \mathrm{in}$. above the floor at the middle of the back wall (Figure 2.4). The offgas exit port is approximately $2.5 \mathrm{in}$. from the control thermocouple. To monitor the simulant temperature, two thermocouples were placed in the Hastelloy X boat (11 in. long, 5 in. wide, and 2.5 in. tall), with the tips of the thermocouples submerged in the simulant. One thermocouple was placed about 2 to $3 \mathrm{in}$. from the front of the boat (end closest to the furnace door), and the second was placed near the center of the boat. A Kaowool pad was used to provide a reasonable seal between the furnace housing, boat thermocouples, and the furnace door. Furnace sweep gas enters the furnace through this Kaowool pad (i.e., front of the boat is slightly cooler than the back of the boat). For all testing, the sweep air flow rate was maintained at 1.0 SCFM.

Table 3.13 provides a summary of the offgas profiles in the furnace and boat during Cycles 51 through 54. Appendix $\mathrm{C}$ provides plots of the furnace and boat temperature profiles. The cross-over temperature

Table 3.13. Temperature Profile in Boat and Furnace During Cycles 51 Through 54

\begin{tabular}{|c|c|c|c|c|c|c|c|c|}
\hline \multirow{3}{*}{$\begin{array}{c}\text { Cycle } \\
\text { No. }\end{array}$} & \multirow{2}{*}{\multicolumn{2}{|c|}{$\begin{array}{c}\text { Cross-Over } \\
\text { Temperature, }{ }^{\circ} \mathrm{C}\end{array}$}} & \multirow{2}{*}{\multicolumn{2}{|c|}{$\begin{array}{c}\text { Temperature } \\
\text { When Furnace } \\
\text { Control First at } \\
\mathbf{7 5 0}^{\circ} \mathrm{C} \\
\end{array}$}} & \multicolumn{4}{|c|}{$\begin{array}{c}\text { Boat Temperature Range } \\
\text { While Furnace at } 750^{\circ} \mathrm{C} \\
\text { Hold } \\
\end{array}$} \\
\hline & & & & & \multicolumn{2}{|c|}{$\begin{array}{c}\text { Front of } \\
\text { Boat }\end{array}$} & \multicolumn{2}{|c|}{$\begin{array}{c}\text { Center of } \\
\text { Boat }\end{array}$} \\
\hline & Front & Center & Front & Center & High & Low & High & Low \\
\hline 51 & 417 & 154 & 803 & 846 & 820 & 803 & 849 & 836 \\
\hline 52 & 181 & 174 & 848 & 861 & 857 & 847 & 869 & 855 \\
\hline 53 & 360 & 296 & 842 & 854 & 851 & 842 & 857 & 842 \\
\hline 54 & 366 & 384 & 841 & 852 & 845 & 837 & 862 & 853 \\
\hline
\end{tabular}


is defined as the point at which the boat temperature exceeds that of the furnace temperature (as measured by the furnace control thermocouple). As shown in Table 3.13, cross-over temperatures at the front and center of the boat are well below $750^{\circ} \mathrm{C}$. When the furnace initially reaches the $750^{\circ} \mathrm{C}$ hold temperature, the temperature of the material in the boat is $50^{\circ} \mathrm{C}$ to $110^{\circ} \mathrm{C}$ warmer. The results in Table 3.13 and Appendix $\mathrm{C}$ strongly support that the temperature in the material in the boat will exceed $750^{\circ} \mathrm{C}$ for the entire 2-hr hold time, and that there is little incentive or justification to control the furnace at a higher temperature.

\subsubsection{Operability of Furnace System Components}

\subsubsection{Furnace Elements}

No degradation was observed in the physical condition or performance of the furnace elements during Cycles 51 through 54. The current and voltage profiles for all runs were essentially the same. The performance and physical condition of the furnace control thermocouple did not change during the tests.

\subsubsection{Boat}

Even though the Hastelloy X boat lost significant mass during Cycles 53 and 54 (Table 3.11), no deep pits were observed, nor was there any indication of localized corrosion attack to the welds. The boat was still in serviceable condition after Cycles 51 through 54. During the testing at $1000^{\circ} \mathrm{C}$ with $1 \mathrm{wt} \%$ chloride salt, the width of the boat would increase by $1 / 32$ in. to $3 / 32$ in. each cycle. During Cycles 51 through 54 , conducted at $750^{\circ} \mathrm{C}$, the boat width remained constant.

\subsubsection{Removal of Calcined Material from Boat}

A hammer and a screwdriver were needed to remove the calcined material from the boat after Cycles 51 and 52. The calcined material was tenaciously bound to the walls of the boat, and significant physical effort was required to thoroughly clean the boat. Figure 3.5 shows the recovered calcined material from Cycle 51.

The calcined material in Cycles 53 and 54 apparently contracted during cooldown and pulled away from the boat walls. The material was removed by inverting the boat, then dropping the boat to a hard surface from a height of several inches. A residual layer was left at the bottom of the boat that required moderate effort to remove.

Calcined material was crushed and sieved to minus $1 / 4$ in. to prepare samples for moisture uptake testing. This size reduction was performed with moderate effort using a mortar and pestle.

\subsubsection{Internal and External Offgas Lines}

During Cycles 51 and 54, only minimal corrosion and salt deposition occurred in the offgas lines. After Cycles 53 and 54, small quantities of loose corrosion products were removed from the internal offgas line and weighed (Table 3.11). The cumulative extent of corrosion and salt deposition in the offgas lines during Cycles 51 through 54 was less than that experienced during a single cycle with $20 \mathrm{~g}$ of salt at $1000^{\circ} \mathrm{C}$. Figure 3.11 shows the minimal salt deposits on the internal offgas line after Cycle 54 (this line was not cleaned during Cycles 51 through 54). In comparison, Figure 3.12 shows a plug that formed in the external offgas line from salt deposition after three cycles of processing $1 \mathrm{wt} \%$ chloride salt $(20 \mathrm{~g})$ at $1000^{\circ} \mathrm{C}$. 


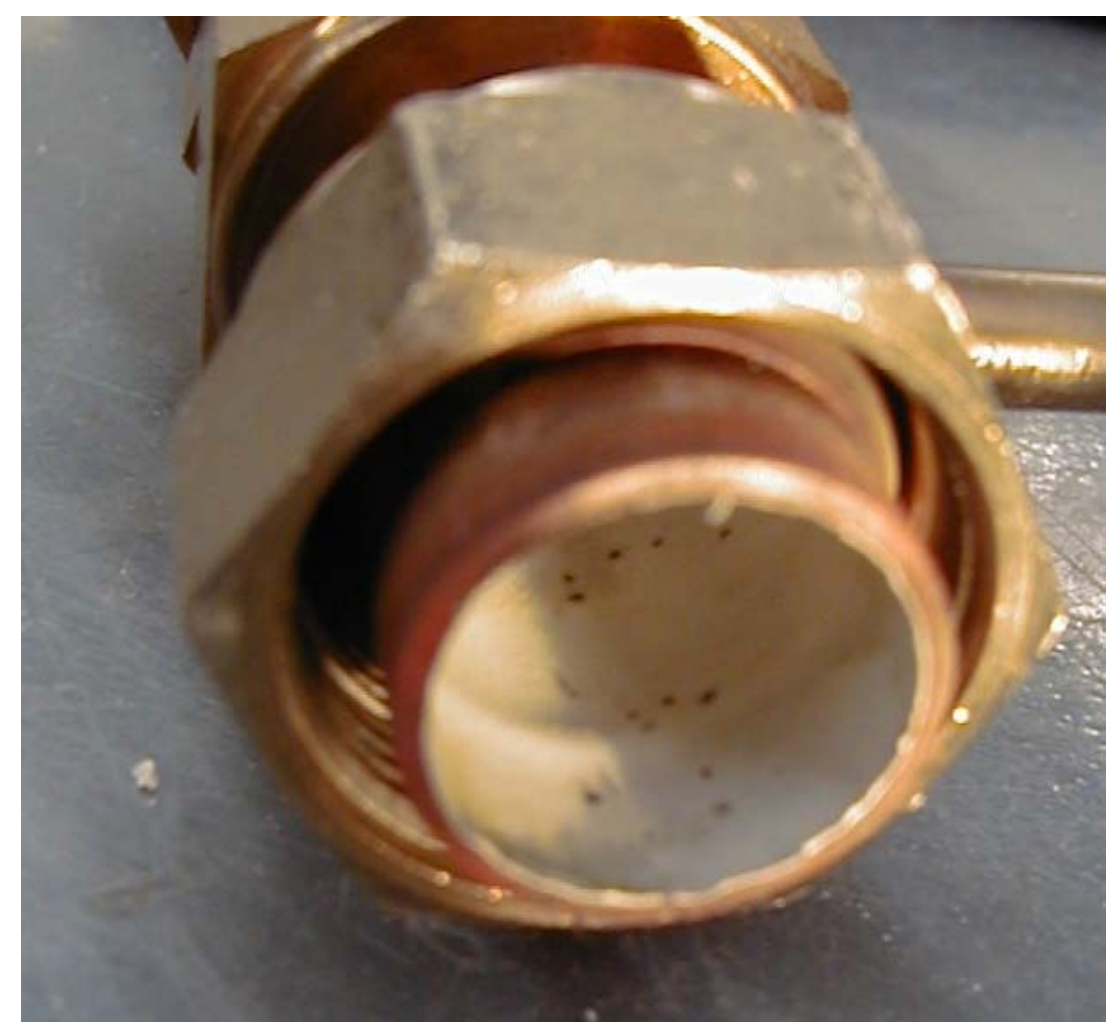

Figure 3.11. Minimal Salt Deposits on Inconel 600 Internal Offgas Line After Cycle 54

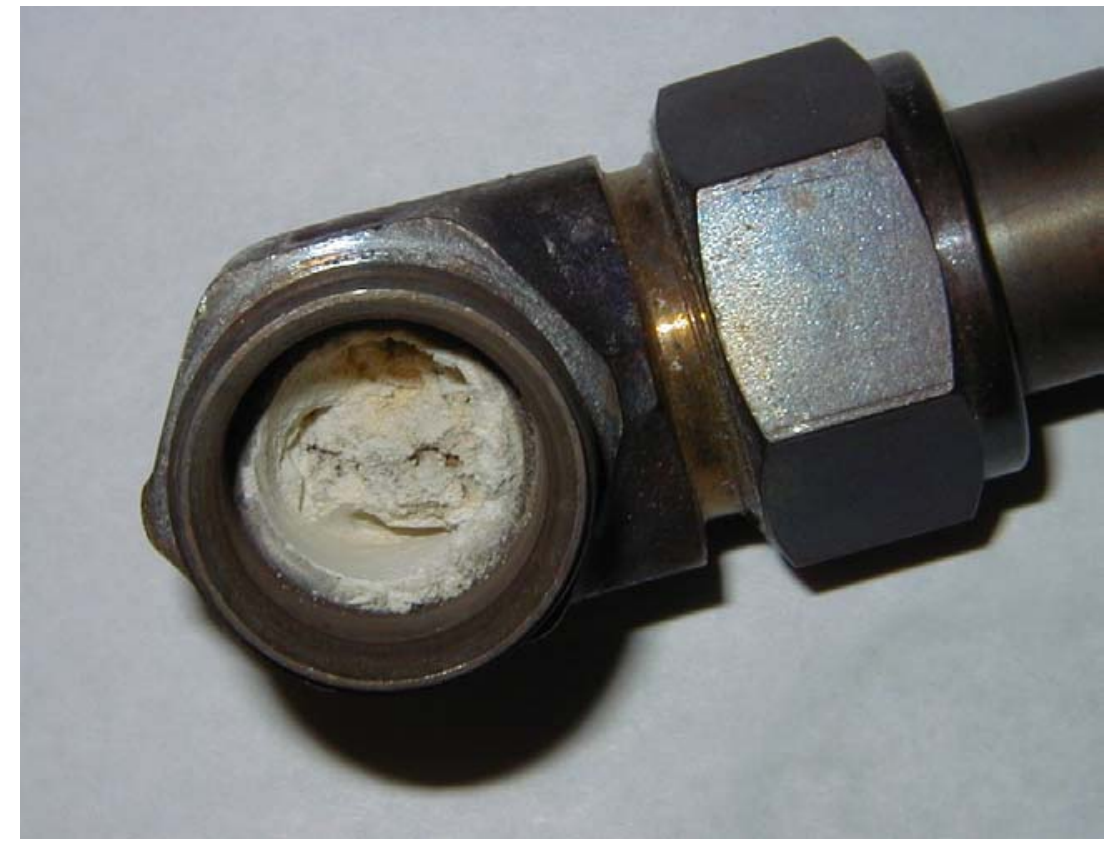

Figure 3.12. Final Bend on Inconel 600 External Offgas Line Plugged with Salt Deposits After Three Cycles of Processing $1 \mathrm{wt} \%$ Chloride Salt at $1000^{\circ} \mathrm{C}$ (Fischer et al. 2002) 


\subsubsection{Filter Element}

Only a small quantity of material was collected on the $5-\mu \mathrm{m}$ filter $(\sim 0.4 \mathrm{~g}$ in each cycle) during Cycles 51 and 52, resulting in very little permanent pressure drop across the filter $\left(\sim 0.1\right.$ in. $\left.-\mathrm{H}_{2} \mathrm{O}\right)$. The material deposited on the filter during Cycles 51 and 52 was a fine, low-density powder that from visual observation appeared identical to the material collected on filters and knockout pots in the previous testing at $1000^{\circ} \mathrm{C}$.

During Cycles 53 and 54, $5.98 \mathrm{~g}$ and $7.18 \mathrm{~g}$ of material, respectively, were collected on the filter. With this material collection, the pressure drop across the filter element increased from about 0.55 to 2.9 in.$\mathrm{H}_{2} \mathrm{O}$. It is estimated that three to five cycles (similar to Cycles 53 and 54) could be completed before blinding the filter element. During the testing with $1 \mathrm{wt} \%$ chloride salt at $1000^{\circ} \mathrm{C}$, it was found that five furnace cycles could be completed before blinding the pleated stainless steel filters.

\subsubsection{Disposition of $\mathrm{HCl}$}

The wet scrubber and chilled condenser effectively captured the $\mathrm{HCl}$ generated in the furnace. Immediately after each test, the offgas lines downstream of the scrubber were disassembled and rinsed to remove any $\mathrm{HCl}$. As a result, no pitting was observed or revealed during leak testing of the offgas system.

\subsection{Post-Calcination Moisture Uptake Testing}

Moisture uptake testing was conducted on fresh and calcined samples from Cycles 51, 52, and 54. Also, a sample of the $\mathrm{CeO}_{2}$ used for preparing the simulants was included in the testing. Calcined simulant from Cycles 52 and 54 were crushed and sieved to prepare size-classified samples (nominally $5 \mathrm{~g}$ each). [At PFP, calcined $\mathrm{PuO}_{2}$ material is passed through a 1/4-in. screen before being loaded into convenience cans for sealing into 3013 containers.] Next, the samples were placed in a preheated oven $\left(250^{\circ} \mathrm{C}\right.$ or $\left.500^{\circ} \mathrm{C}\right)$ for $30 \mathrm{~min}$ to remove moisture that may have been absorbed between the time the furnace tests were completed and when the moisture uptake testing was initiated. After heating, the samples were cooled (in a desiccator), and then placed into a controlled humidity chamber (51\% relative humidity). Sample weight gain (moisture uptake) was monitored as a function of time.

The samples used for the moisture uptake testing, the initial drying temperature, and the weight loss results from the initial 30-min drying are shown in Table 3.14. All of the Cycle 51 and 52 samples $\left(\mathrm{NaCl} / \mathrm{KCl}\right.$ simulant) were dried at $500^{\circ} \mathrm{C}$, since decomposition of the salts was expected to be negligible. The percent weight loss of the fresh and calcined simulants is only slightly greater than the percent weight loss of $\mathrm{CeO}_{2}$, which is consistent with $\mathrm{NaCl}$ and $\mathrm{KCl}$ not forming hydrated species.

The weight loss of the Fresh Cycle 54 sample $\left(\mathrm{NaCl} / \mathrm{KCl} / \mathrm{MgCl}_{2}\right.$ simulant, with $\mathrm{MgCl}_{2} \cdot 6 \mathrm{H}_{2} \mathrm{O}$ as the source of $\mathrm{MgCl}_{2}$ ), calcined at $250^{\circ} \mathrm{C}$, is $4.29 \mathrm{wt} \%$. In comparison, if all waters of hydration from the $\mathrm{MgCl}_{2} \cdot 6 \mathrm{H}_{2} \mathrm{O}$ were removed, the theoretical weight loss would be $4.22 \mathrm{wt} \%$. In addition to the removal of waters of hydration, weight loss from the $\mathrm{CeO}_{2}$, which comprises $71.8 \mathrm{wt} \%$ of the Fresh Cycle 54 sample, also contributed to the weight loss of the sample. The weight loss exhibited by the Fresh Cycle 54 sample, dried at $250^{\circ} \mathrm{C}$, suggests very little, if any, of the $\mathrm{MgCl}_{2}$ decomposed. This finding is consistent with Smith et al. (2000), who list the minimum temperature for $\mathrm{MgCl}_{2}$ decomposition at $350^{\circ} \mathrm{C}$. This finding also suggests that a low-temperature hold (e.g., at $\left.250^{\circ} \mathrm{C}\right)$ during thermal processing could be used to drive off hydrate water without incurring pyrohydrolytic $\mathrm{HCl}$ formation. 
Table 3.14. Sample Descriptions and Initial Drying Results

\begin{tabular}{|c|c|c|c|c|}
\hline Sample & $\begin{array}{c}\text { Drying } \\
\text { Temperature, } \\
{ }^{\circ} \mathrm{C} \\
\end{array}$ & $\begin{array}{c}\text { Initial } \\
\text { Weight, } \\
\text { g } \\
\end{array}$ & $\begin{array}{c}\text { Dry } \\
\text { Weight, } \\
\text { g } \\
\end{array}$ & $\begin{array}{c}\% \\
\text { Weight } \\
\text { Loss } \\
\end{array}$ \\
\hline $\begin{array}{l}\mathbf{C e O}_{2} \\
\text { (Used for simulant makeup) }\end{array}$ & 500 & 5.0070 & 5.0049 & 0.042 \\
\hline \multicolumn{5}{|c|}{ NaCl/KCI Simulant Samples } \\
\hline $\begin{array}{l}\text { Fresh Cycle } 51 \\
\text { (Non-calcined feed, fine powder) }\end{array}$ & 500 & 5.0041 & 5.0016 & 0.050 \\
\hline $\begin{array}{l}\text { Post Cycle } 52 \text { (-1/4-in. mesh) })^{(\mathbf{a})} \mathbf{5 0 0}^{\circ} \mathbf{C} \\
\text { (Collected from boat, sample was } \\
\text { previously calcined at } 750^{\circ} \mathrm{C} \text {; }\end{array}$ & 500 & 5.0053 & 5.0025 & 0.054 \\
\hline $\begin{array}{l}\text { Post Cycle } 52 \text { Crucible }\left(-16 \text { mesh) } 500^{\circ} \mathrm{C}\right. \\
\text { (Collected from crucible; previously } \\
\left.\text { calcined at } 750^{\circ} \mathrm{C}\right)\end{array}$ & 500 & 5.0026 & 4.999 & 0.054 \\
\hline \multicolumn{5}{|c|}{$\mathrm{NaCl} / \mathrm{KCl} / \mathrm{MgCl}_{2}$ Simulant Samples } \\
\hline $\begin{array}{l}\text { Fresh Cycle } 54 \\
\text { (Non-calcined feed, fine powder) }\end{array}$ & 250 & 5.0035 & 4.7890 & 4.29 \\
\hline $\begin{array}{l}\text { Fresh Cycle } 54 \\
\text { (Non-calcined feed, fine powder) }\end{array}$ & 500 & 4.5871 & 4.3632 & 4.88 \\
\hline $\begin{array}{l}\text { Post Cycle } 54 \text { (-1/4-in. mesh) })^{(\mathbf{a})} \mathbf{2 5 0}^{\circ} \mathrm{C} \\
\text { (Collected from boat, sample was } \\
\text { previously calcined at } 750^{\circ} \mathrm{C} \text { ) }\end{array}$ & 250 & 5.0021 & 4.9973 & 0.10 \\
\hline $\begin{array}{l}\text { Post Cycle } 54 \text { (-1/4-in. mesh) } \\
\text { (Collected from boat, sample was }^{(\mathbf{a})} \mathbf{5 0}^{\circ} \mathbf{C} \\
\text { previously calcined at } 750^{\circ} \mathrm{C} \text { ) }\end{array}$ & 500 & 5.007 & 4.9898 & 0.34 \\
\hline $\begin{array}{l}\text { Post Cycle } 54 \text { Crucible }\left(-16 \text { mesh) } 500^{\circ} \mathbf{C}\right. \\
\text { (Collected from crucible, sample was } \\
\text { previously calcined at } 750^{\circ} \mathrm{C} \text { ) }\end{array}$ & 500 & 5.0023 & 4.9675 & 0.70 \\
\hline
\end{tabular}

The percent weight loss of the Fresh Cycle 54 sample dried at $500^{\circ} \mathrm{C}(4.88 \mathrm{wt} \%)$ compared to the Fresh Cycle 54 sample dried at $250^{\circ} \mathrm{C}(4.29 \mathrm{wt} \%)$ suggests that a fraction of the $\mathrm{MgCl}_{2}$ decomposed to $\mathrm{MgO}$ and $\mathrm{HCl}$, the latter of which would have evolved from the sample. Smith et al. (2000) report that when $\mathrm{MgCl}_{2}$ is calcined at between $350^{\circ} \mathrm{C}$ and $500^{\circ} \mathrm{C}$ in the presence of moisture, decomposition occurs according to the following reaction:

$$
\mathrm{MgCl}_{2}+\mathrm{H}_{2} \mathrm{O} \rightarrow \mathrm{Mg}(\mathrm{OH}) \mathrm{Cl}+\mathrm{HCl}
$$

For the Fresh Cycle 54 sample to experience a net $1 \mathrm{wt} \%$ weight loss due to this reaction, the sample would have to evolve $1.92 \mathrm{wt} \%$ of the initial sample mass as $\mathrm{HCl}$ (or $1.86 \mathrm{wt} \%$ as evolved chloride), as a result of the offsetting weight gained when the $(\mathrm{OH})$ group was added to the sample. Therefore, the $0.59 \mathrm{wt} \%$ additional weight loss $(4.88$ to $4.29 \mathrm{wt} \%)$ that was measured when drying the sample at $500^{\circ} \mathrm{C}$ corresponds to an evolution of $1.10 \mathrm{wt} \%$ of the initial sample mass weight as chloride in $\mathrm{HCl}$, which is equivalent to $40 \mathrm{wt} \%$ of the chloride associated with the initial $\mathrm{MgCl}_{2}$. 
The much lower percent weight losses of the Post Cycle 54 samples indicates that much of the $\mathrm{MgCl}_{2}$ was decomposed when the material was processed in the furnace at $750^{\circ} \mathrm{C}$. The relatively low weight losses could also be partially attributed to the materials being stored in closed jars. The materials may not have reached equilibrium moisture content before being dried for these tests. A comparison of the two Post Cycle 54 (-1/4 in. mesh) samples shows that the sampled dried at $500^{\circ} \mathrm{C}$ exhibited a weight loss about $0.24 \mathrm{wt} \%$ greater than the sample dried at $250^{\circ} \mathrm{C}$. This observation is consistent with the behavior of the Fresh Cycle 54 samples, and indicates additional $\mathrm{MgCl}_{2}$ decomposition occurred in the Post Cycle 54 (-1/4-in. mesh) sample during the drying at $500^{\circ} \mathrm{C}$.

After the samples were dried and weighed, they were placed into a controlled humidity chamber (51\% relative humidity), and weight gain (moisture uptake) was monitored as a function of time. Figure 3.13 shows the moisture uptake data from the $\mathrm{CeO}_{2}$ sample and the samples from Cycles 51 and 52. Fresh Cycle 51 and Post Cycle 52 samples exhibited moisture uptake behavior that is only slightly greater than that exhibited by the $\mathrm{CeO}_{2}$ sample. The results in Figure 3.13 also show that the particle size of the Post Cycle 52 samples had no apparent effect on the moisture uptake behavior.

Figure 3.14 shows the moisture uptake data of the Cycle 54 samples during $48 \mathrm{hr}$ of testing. Figure 3.15 is an expanded view of the first $12 \mathrm{hr}$ of moisture uptake testing. The lower moisture uptake of the Fresh Cycle 54 sample dried at $500^{\circ} \mathrm{C}$ compared with the sample dried at $250^{\circ} \mathrm{C}$ is consistent with the apparent loss of $\mathrm{MgCl}_{2}$ during drying at the higher temperature. A similar trend occurs between the Post Cycle 54 (-1/4-in. mesh) samples dried at the two temperatures. The Post Cycle 54 Crucible sample exhibited higher initial moisture uptake than the Post Cycle 54 (-1/4 in. mesh) samples, which is attributed to the smaller average particle size of the crucible sample. However, the Post Cycle 54 sample has a slightly different composition than that of the Post Cycle 54 (-1/4-in. mesh) samples, which contain metal corrosion products (i.e., -1/4-in. mesh samples were collected from the boat); therefore, rigorous comparisons cannot be made.

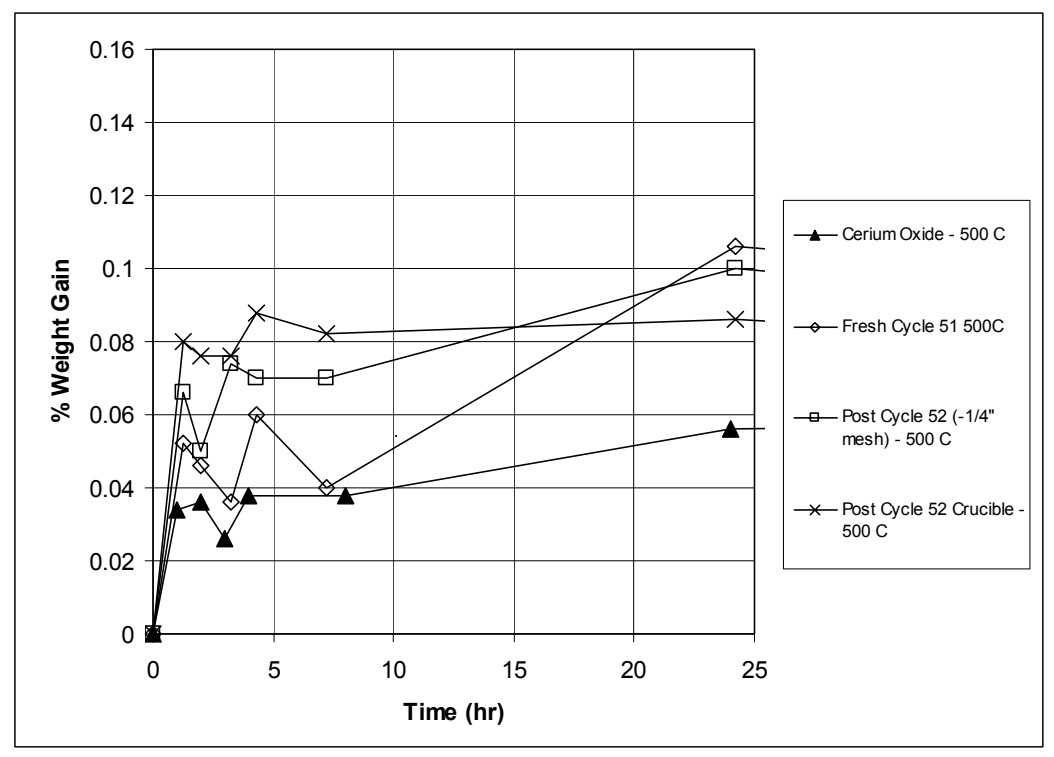

Figure 3.13. Percent Weight Gain of $\mathrm{CeO}_{2}$ and Cycle 51 and 52 Samples $(\mathrm{NaCl} / \mathrm{KCl}$ simulant). Samples were dried at $500^{\circ} \mathrm{C}$ for $30 \mathrm{~min}$ and then placed in a nominal $51 \%$ relative humidity environment. 


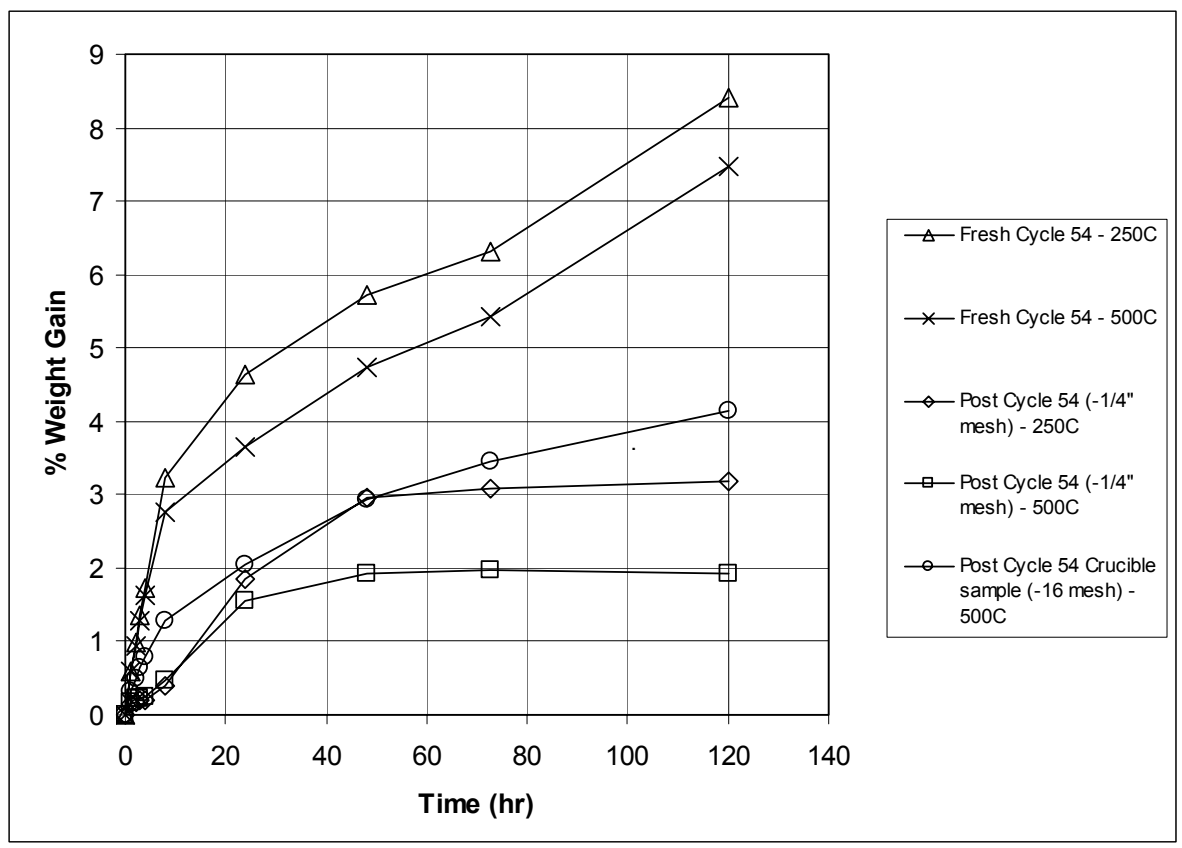

Figure 3.14. Percent Weight Gain of Cycle 54 Samples $\left(\mathrm{NaCl} / \mathrm{KCl} / \mathrm{MgCl}_{2}\right.$ simulant). Samples were dried at $250^{\circ} \mathrm{C}$ or $500^{\circ} \mathrm{C}$ and then placed in a nominal $51 \%$ relative humidity environment.

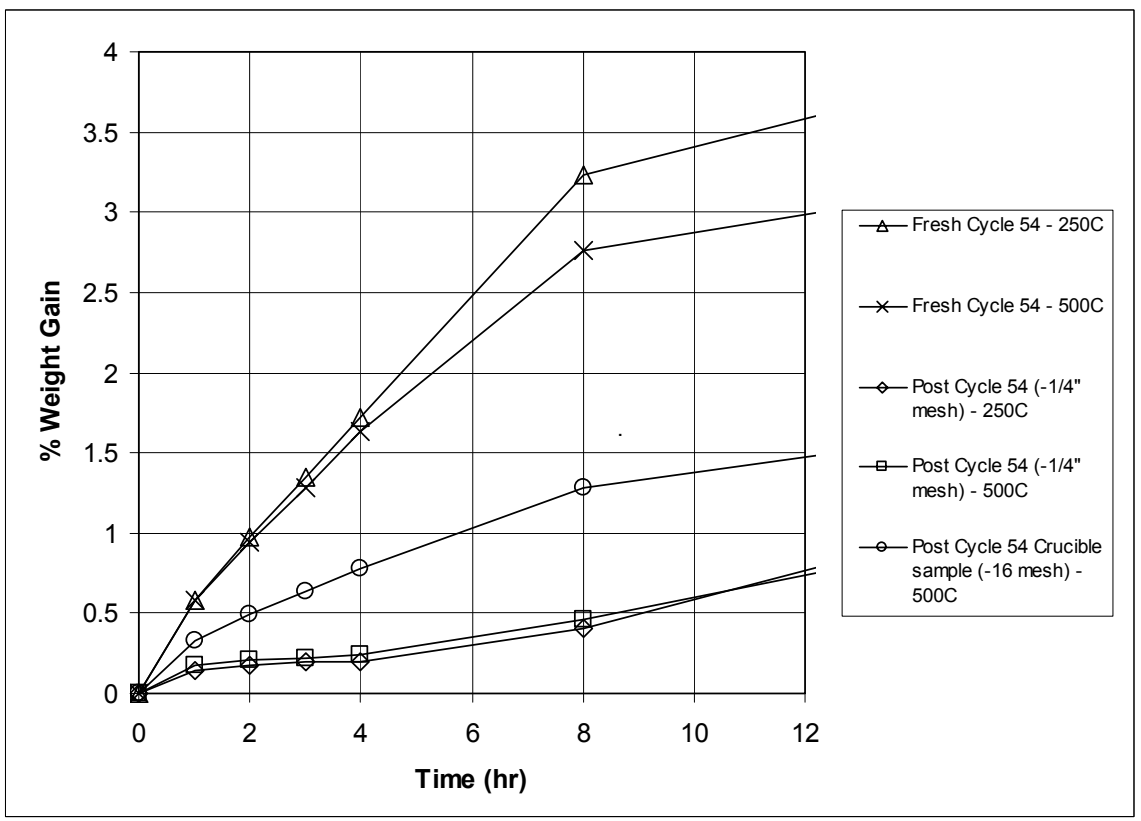

Figure 3.15. Expanded View of Percent Weight Gain of Cycle 54 Samples $(\mathrm{NaCl} / \mathrm{KCl} / \mathrm{MgCl} 2$ simulant). Samples were dried at $250^{\circ} \mathrm{C}$ or $500^{\circ} \mathrm{C}$ and then placed in a nominal $51 \%$ relative humidity environment. 
In summary, samples from the $\mathrm{NaCl} / \mathrm{KCl}$ simulant (Cycles 51 and 52) only gained about $0.1 \mathrm{wt} \%$ after $24 \mathrm{hr}$ in the controlled humidity chamber. Samples from the $\mathrm{NaCl} / \mathrm{KCl} / \mathrm{MgCl}_{2}$ simulant (Cycle 54) that were crushed and screened to less than $1 / 4$ in. $(6.35 \mathrm{~mm})$ exhibited a weight gain of $\sim 0.5 \mathrm{wt} \%$ after 8 to $10 \mathrm{hr}$, while a sample that was screened to less than 16 mesh $(1 \mathrm{~mm})$ exhibited a weight gain of $\sim 0.5 \mathrm{wt} \%$ after only $2 \mathrm{hr}$. These results show that meeting the $0.5 \mathrm{wt} \%$ moisture limit established by the DOE 3013 Standard will be challenging if $\mathrm{HCP}$ items are encountered that contain appreciable quantities of $\mathrm{MgCl}_{2}$ and if thermal stabilization is performed at $750^{\circ} \mathrm{C}$ in the $\mathrm{RMC}$ line (relative humidity in the RMC line can reach $60 \%$ ).

\section{NOTES:}

A number of factors should be considered when interpreting the results of moisture uptake testing to predict the behavior of actual $\mathrm{HCP}$ items (containing the same chloride salts) after thermal stabilization at $750^{\circ} \mathrm{C}$. The $\mathrm{CeO}_{2}$ used in these tests exhibited a significantly lower moisture uptake than $\mathrm{CeO}_{2}$ used in earlier tests (PNNL Letter Report 41291-RPT02, "Evaluation of Solids Rinsing to Treat PFP High Chloride Plutonium Solids," transmitted to P. Sato, FH, by K. L. Silvers, PNNL, December 20, 2002). Comparison of the test data suggests that the $\mathrm{CeO}_{2}$ used in the earlier tests had a very low surface area. The moisture uptake of the samples in the current tests would be $0.3 \%$ to $0.5 \%$ higher if a higher surface area $\mathrm{CeO}_{2}$ had been used in preparing the fresh simulant.

The size of the samples used in current moisture uptake tests was nominally $5 \mathrm{~g}$, while the samples used in the earlier tests were nominally $10 \mathrm{~g}$. Also, all of the samples in the earlier tests were finely divided powders. The finely divided powders would promote higher initial moisture uptake rates, which would counteract, to some extent, the effect of the larger sample size.

Partial decomposition of $\mathrm{MgCl}_{2}$ likely occurred when the samples in the current testing were dried at $500^{\circ} \mathrm{C}$. As a result, the weight gains shown in Figure 3.14 for the Post Cycle 54 crucible and (-1/4-in. mesh) sample dried at $500^{\circ} \mathrm{C}$ are probably lower than would have occurred if the samples had been dried at $250^{\circ} \mathrm{C}$.

Finally, the results are based on weight gains in a humidifier, where the air was stagnant and mass transfer limitations existed between the sulfuric acid solution used to control humidity and the solids (relative humidity as low as $40 \%$ for the first several hours of moisture uptake). It is anticipated that the initial moisture uptake rates would be greater in a glovebox with well-mixed humid air flow, as would be experienced in the RMC line at PFP. 


\subsection{References}

Fischer, C. M., M. R. Elmore, A. J. Schmidt, M. A. Gerber, D. S. Muzatko, S. R. Gano, and B. M. Thornton. 2002. Evaluation of PFP Furnace Systems for Thermal Stabilization of Washed High Chloride Plutonium Oxide Items. PNNL-14260, Pacific Northwest National Laboratory, Richland, WA.

Reinhard, G., and D. Naumann. 1968. "Die Löslichkeit der Ceroxide in Alkalichlorschmelzen," Zeitschrift für Physikalische Chemie (Leipzig) 238:308-320.

Smith, D. M., M. P. Neu, E. Garcia, and L. A. Morales. 2000. "Hydration of Plutonium Oxide and Process Salts, $\mathrm{NaCl}, \mathrm{KCl}, \mathrm{CaCl}_{2}, \mathrm{MgCl}_{2}$ : Effect of Calcination on Residual Water and Rehydration." Waste Management 20:479-490. 


\section{Appendix A}

\section{Furnace Operation for HCP Oxide Testing}

with $750^{\circ} \mathrm{C}$ Hold Temperature 


\section{Appendix A}

\section{Furnace Operation for HCP Oxide Testing with $750^{\circ} \mathrm{C}$ Hold Temperature}

1. Clean furnace and/or replace heating elements and any other corroded or otherwise damaged components, including the offgas system.

2. Document condition of the test apparatus by photographing the inside of the furnace and (as possible) the insides of the offgas system components. Weigh the boat, crucible, baffle, the Inconel-690 offgas internal offgas line, the Inconel 600 offgas line, and the filter element.

3. Add fresh water to the scrubber tank.

4. Mix water in scrubber tank and collect sample.

5. Collect a sample of $\mathrm{CeO}_{2} / \mathrm{Cl}$ simulant.

6. Load ceramic crucible with simulant, and place in center of boat.

7. Load a boat with $\mathrm{CeO}_{2} / \mathrm{Cl}$ simulant.

8. Place corrosion coupons into the boat half immersed in powder.

9. Weigh boat + coupons + crucible, and record weight on Data Sheet.

10. Position two Type $\mathrm{K}$ thermocouples into the $\mathrm{CeO}_{2}$ powder in the boat (one in front, one in back), and plug thermocouples into reader/datalogger.

11. Place the loaded boat into furnace, close the door and turn on controller.

12. Start offgas blower and set offgas flow rate at 1 SCFM.

13. Heat from room temp to $500^{\circ} \mathrm{C} @ 300^{\circ} \mathrm{C} / \mathrm{hr}$

14. Heat from $500^{\circ} \mathrm{C}$ to $700^{\circ} \mathrm{C} @ 200^{\circ} \mathrm{C} / \mathrm{hr}$

15. Heat from $700^{\circ} \mathrm{C}$ to $750^{\circ} \mathrm{C} @ 125^{\circ} \mathrm{C} / \mathrm{hr}$

16. Hold temperature@ $750^{\circ} \mathrm{C}$ for 2 hr.

17. Turn off controller and allow to cool to below $200^{\circ} \mathrm{C}$ before removing boat.

18. Remove boat and set aside to cool.

19. Weigh boat + coupons + crucible and record on Data Sheet. 
20. Before emptying the boat removed from the furnace, photograph the boat with simulant and the corrosion coupon set.

21. Weigh crucible $+\mathrm{CeO}_{2} / \mathrm{Cl}$, and record on Data Sheet. Place material in crucible in a sample vial. Label the vial with cycle number, and store the vial in archive sample storage for later analysis.

22. Empty the boat when cool enough, and collect calcined material in a jar labeled with the cycle number.

23. Clean out boat by dry brushing with nonmetallic brush to remove residue but without significantly affecting corrosion products if any.

24. Carefully dry brush the corrosion coupons with same or similar brush.

25. Photograph the empty boat (as necessary), thermocouple, and coupons.

26. Weigh the boat and coupons, and record on Data Sheet.

27. Check boat dimensions, and resize if significant bowing is observed.

28. Photograph the air baffle (if any changes in appearance noted).

29. Brush off the air baffle, reweigh, and record on Data Sheet.

30. Photograph the inside of the furnace (as necessary) when cool enough, and clean out any residue inside the furnace cavity.

31. Remove the internal offgas line from the back of the furnace when cool.

32. Weigh the internal offgas line, and record on Data Sheet.

33. Inspect the inside, and photograph if possible.

34. If significant plugging is noted, brush out the tube with a nonmetallic brush, weigh, and record data and observations.

35. Remove the external offgas line when cool.

36. Weigh the external offgas line, and record on Data Sheet.

37. Inspect the inside, and photograph if possible.

38. If significant plugging is noted, brush out the tube with a nonmetallic brush, weigh, and record data and observations.

39. Remove the filter element when cool.

40. Weigh the filter element, and record on Data Sheet.

41. Collect sample from scrubber. Label sample with cycle number. 
42. Drain scrubber and collect scrubber water. Weigh scrubber water, and record on Data Sheet.

43. Wash scrubber.

44. Neutralize spent scrubber water.

45. Reassemble the furnace/offgas system to prepare for the next cycle.

46. Repeat steps $1-45$ for next cycle. 
Table A.1. Matrix of Parameters to be Measured During Testing

\begin{tabular}{|l|l|l||}
\hline \multicolumn{1}{|c|}{ Parameter } & \multicolumn{1}{|c||}{ Frequency ${ }^{(a)}$} & \multicolumn{1}{c||}{ Method } \\
\hline Furnace Temperature & Continuously & Furnace controller \\
\hline Boat/Simulant Temperature & Once per $10 \mathrm{sec}$ & Thermocouple readout/datalogger \\
\hline $\begin{array}{l}\text { Offgas Line Temperature near } \\
\text { Furnace Exit }\end{array}$ & Once per $10 \mathrm{sec}$ & Thermocouple readout/datalogger \\
\hline Offgas Flow Rate & Once per hour & Visual/Manual - Data Sheet \\
\hline Condition of Boat w/Coupons & Once per cycle & Photograph/written observations ${ }^{(b)}$ \\
\hline Condition of Cleaned Boat & Once per cycle & Photograph/written observations \\
\hline Condition of Cleaned Coupons & Once per cycle & Photograph/written observations \\
\hline Weight of Boat & Once per cycle & Data sheet \\
\hline Weight of Coupons & Once per cycle & Data sheet \\
\hline Weight of Crucible & Once per cycle & Data sheet \\
\hline $\begin{array}{l}\text { Condition of Furnace Interior } \\
\text { (includes heating elements) }\end{array}$ & Once per cycle & Photograph/written observations \\
\hline Heater Element Performance & Once per 10 sec & Voltage/Current - Datalogger \\
\hline $\begin{array}{l}\text { Condition of Offgas Line } \\
\text { (Section exiting furnace) }\end{array}$ & Once per cycle & Photograph/written observations \\
\hline Weight of Internal Offgas Line & Once per cycle & Photograph/written observations \\
\hline Weight of External Offgas Line & Once per cycle & Photograph/written observations \\
\hline $\begin{array}{l}\text { Condition of Filter Element and } \\
\text { Filter Holder }\end{array}$ & Once per cycle ${ }^{(\mathrm{c})}$ & Photograph/written observations \\
\hline $\begin{array}{l}\text { Weights of Filter Element } \\
\text { Mass of Spent Scrubber Water }\end{array}$ & Once per cycle & Data sheet \\
\hline $\begin{array}{l}\text { As testing progresses, the monitoring frequency of any parameter may be adjusted up or down as } \\
\text { determined necessary by the principal investigator. } \\
\text { Photographs, observations and other recorded data shall clearly identify the cycle number and other } \\
\text { pertinent information. } \\
\text { The filter element may need to be monitored more frequently (e.g., a DP cell to measure pressure } \\
\text { drop from plugging). This will be determined from initial testing, and additional monitoring added } \\
\text { at that time if necessary. }\end{array}$ & Data sheet \\
\hline
\end{tabular}


Appendix B

X-ray Patterns from XRD Analysis 


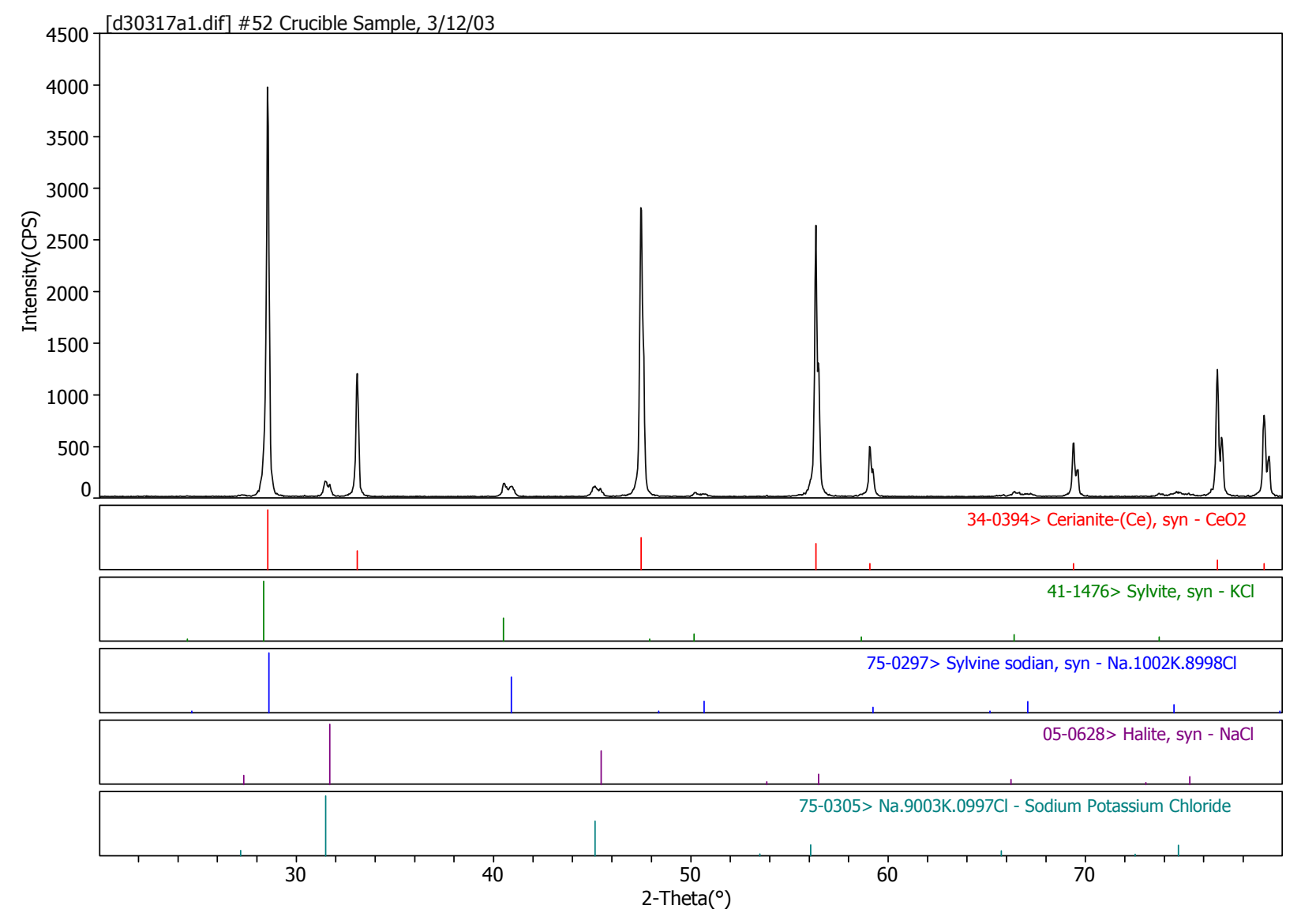

Figure B.1. Full-scale XRD Pattern for Cycle 52 Crucible Sample

Sample: \#52 Crucible Sample, 3/12/03

Scan: 2Theta-Omega, 2.00-80.00@0.04\%2s

File: D30317A

\section{Phase/Qualification/Semi Quant}

Cerianite, CeO2, PDF 34-0394/Positive ID/ 80 wt\%

Sylvite, KCl, PDF 41-1476/Positive ID/<10 wt\%

Sylvite [Solid-Solution/Binary Salt, Na $\sim 0.1$ ], PDF 75-0297/Positive ID $/<5 \mathrm{wt} \%$

Halite, $\mathrm{NaCl}$, PDF 05-0628/Positive ID $/<5$ wt $\%$

Halite [Solid-Solution/Binary Salt, Na $\sim 0.9$ ], PDF 75-0305/Positive ID $/<5$ wt $\%$

\section{Notes}

[1] Sodium content in binary salt was approximate.

B. 1 


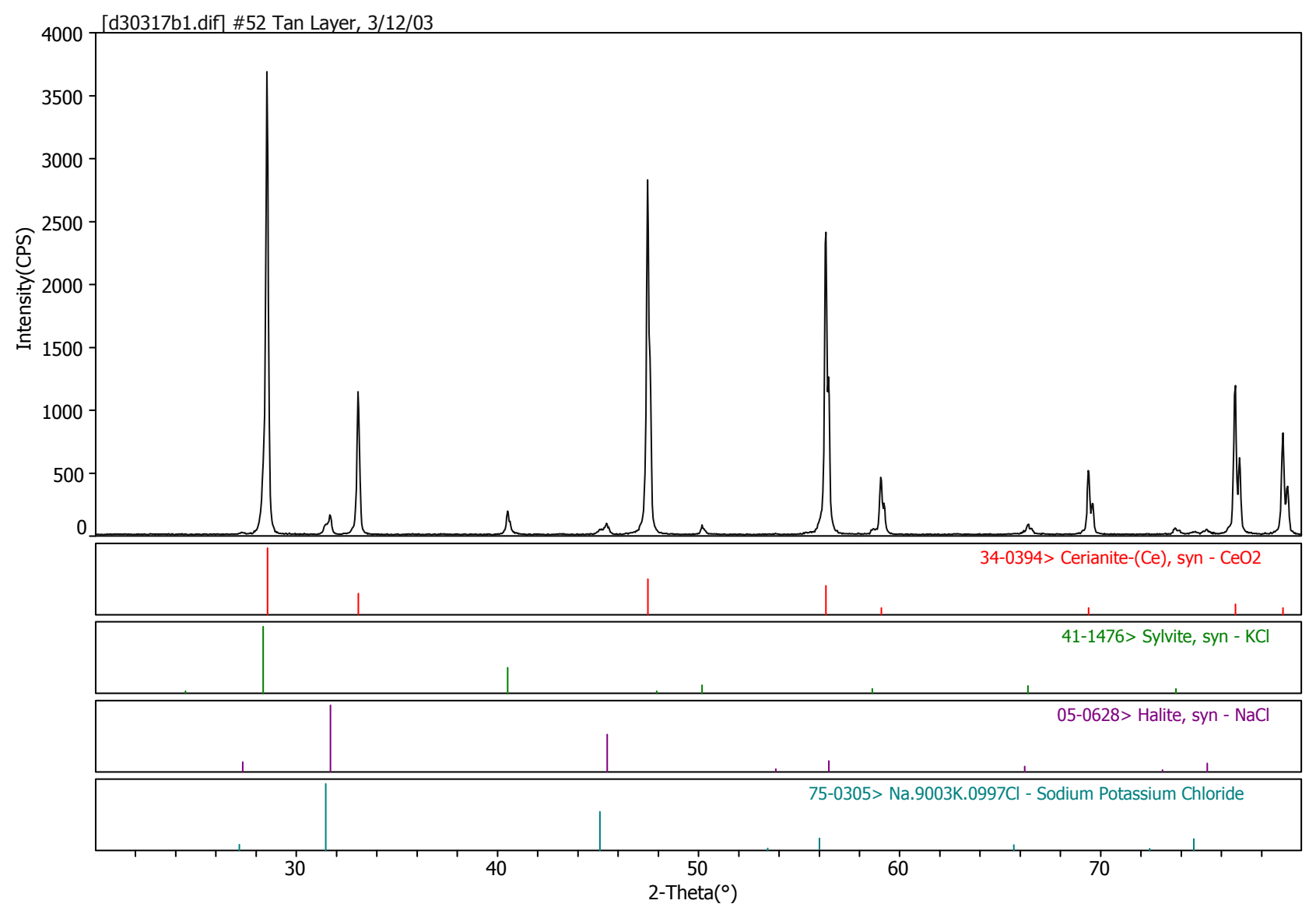

Figure B.2. Full-scale XRD Pattern for Cycle 52 Tan Layer Sample

Sample: \#52 Tan Layer, 3/12/03

Scan: 2Theta-Omega, 2.00-80.00 @ 0.04\% $/ 2 \mathrm{~s}$

File: D30317B

\section{Phase/Qualification/Semi Quant}

Cerianite, CeO2, PDF 34-0394/Positive ID/ 85 wt\%

Sylvite, $\mathrm{KCl}$, PDF 41-1476/Positive ID/ 10 wt $\%$

Halite, $\mathrm{NaCl}$, PDF 05-0628/Positive ID $/<5 \mathrm{wt} \%$

Halite [Solid-Solution/Binary Salt, Na $\sim 0.9$ ], PDF 75-0305/Positive ID $/<5$ wt $\%$

\section{$\underline{\text { Notes }}$}

[1] Sodium content in binary salt was approximate. 


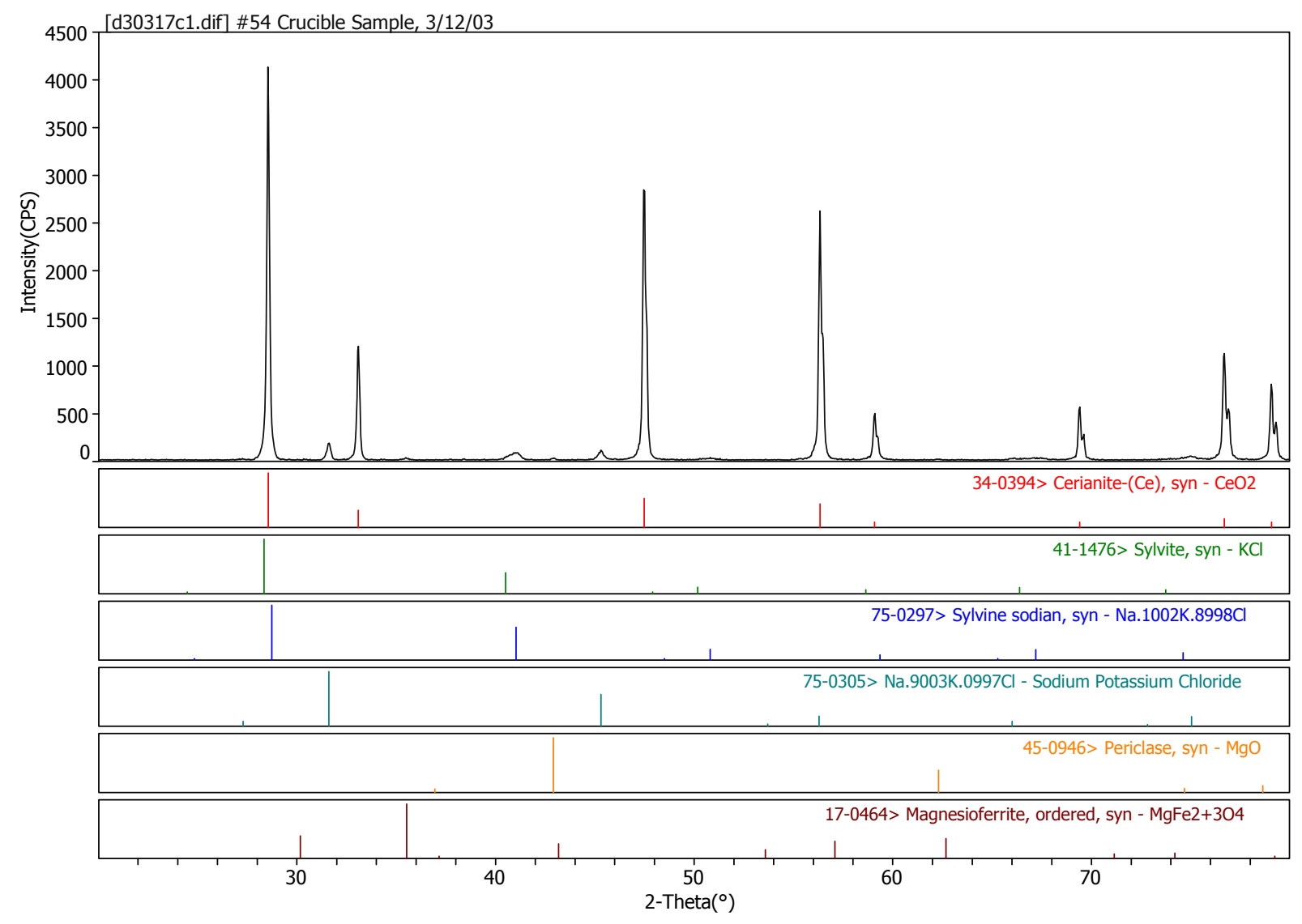

Figure B.3. Full-scale XRD Pattern for Cycle 54 Crucible Sample

Sample: \#54 Crucible Sample, 3/12/03

Scan: 2Theta-Omega, 2.00-80.00@0.04\% $/ 2 \mathrm{~s}$

File: D30317C

\section{Phase/Qualification/Semi Quant}

Cerianite, CeO2, PDF 34-0394/Positive ID/ 90 wt\%

Sylvite, KCl, PDF 41-1476/Positive ID $/<5 \mathrm{wt} \%$

Sylvite [Solid-Solution/Binary Salt, Na $\sim 0.1$ ], PDF 75-0297/Positive ID $/<5 \mathrm{wt} \%$

Halite [Solid-Solution/Binary Salt, Na $\sim 0.9$ ], PDF 75-0305/Positive ID $/<5 \mathrm{wt} \%$

Periclase, MgO, PDF 45-0946/Probable ID/<1 wt $\%$

Magnesioferrite*, MgFe2O4, PDF 17-0464/Tentative ID/<1 wt $\%$

\section{$\underline{\text { Notes }}$}

[1] Sodium content in binary salt was approximate.

[2] Presence of Magnesioferrite* (spinel-type) was indicated by only one peak: (311)/100\%@ 35.5\%2Theta.

[3] Another spinel-type (and/or another phase/structure) may have accounted for this peak. 


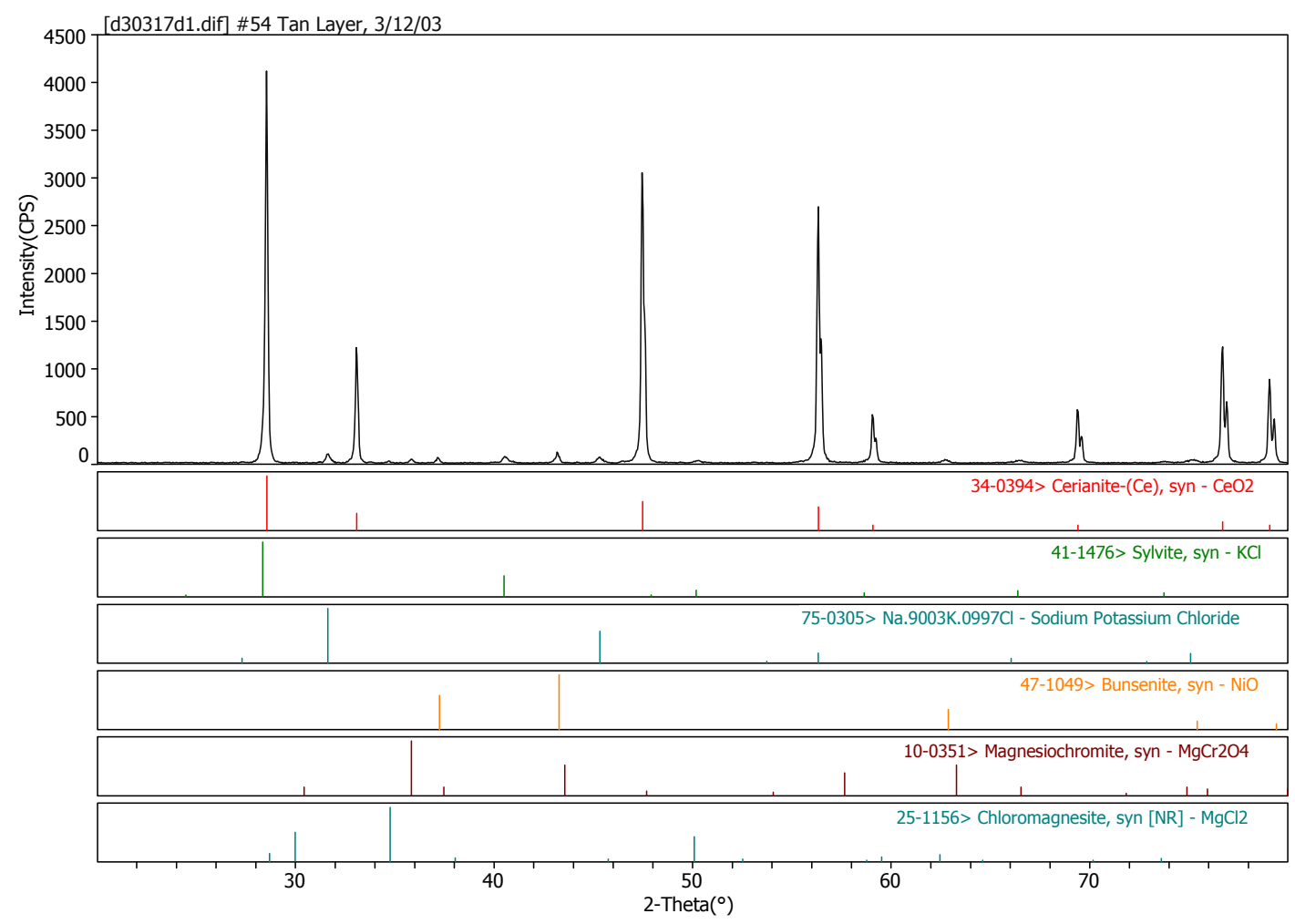

Figure B.4. Full-scale XRD Pattern for Cycle 54 Tan Layer Sample

Sample: \#54 Tan Layer, 3/12/03

Scan: 2Theta-Omega, 2.00․ $80.00^{\circ} @ 0.04^{\circ} / 2 \mathrm{~s}$

File: D30317D

\section{Phase/Qualification/Semi Quant}

Cerianite, CeO2, PDF 34-0394/Positive ID/ 90 wt\%

Sylvite, KCl, PDF 41-1476/Positive ID/ $<5 \mathrm{wt} \%$

Halite [Solid-Solution/Binary Salt, Na $\sim 0.9$ ], PDF 75-0305/Positive ID $/<5$ wt $\%$

Bunsenite, NiO, PDF 47-1049/Probable ID/ $<5$ wt $\%$

Magnesiochromite*, MgCr2O4, PDF 10-0351/Tentative ID $/<1 \mathrm{wt} \%$

Chloromagnesite**, MgCl2, PDF 25-1156/Tentative ID/ $<1 \mathrm{wt} \%$

\section{Notes}

[1] Sodium content in binary salt was approximate.

[2] Presence of Magnesiochromite* (spinel-type) was indicated by only one peak: (311)/100\%@ 35.8 2Theta.

[3] Another spinel-type* (and/or another phase/structure) may have accounted for this peak.

[4] Presence of Chloromagnesite** was indicated by only one peak: (104)/100\% @ 34.5²Theta.

[5] Another phase/structure** may have accounted for this peak. 


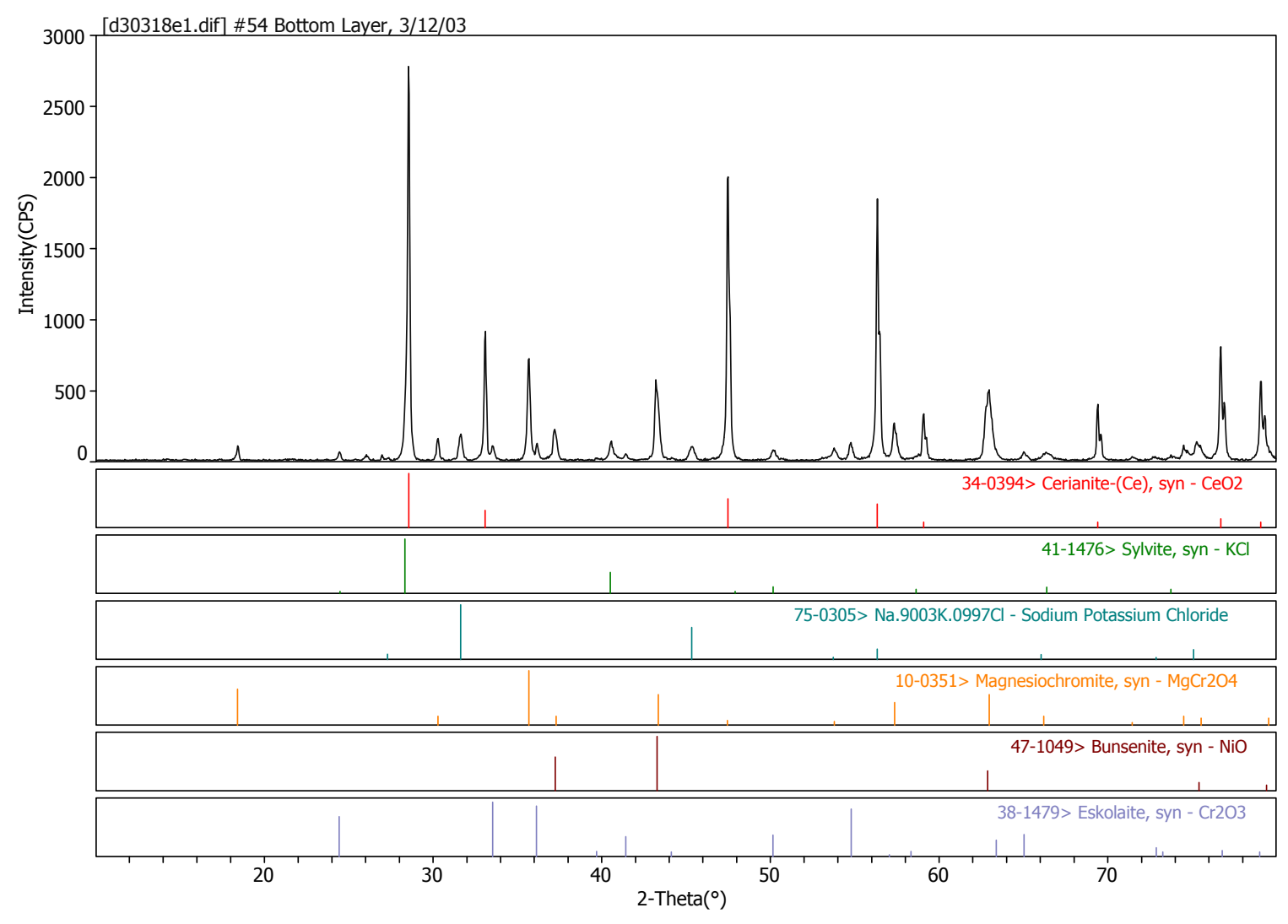

Figure B.5. Full-scale XRD Pattern for Cycle 54 Bottom Layer Sample (Unidentified Peaks Not Illustrated)

Sample: \#54 Bottom Layer, 3/12/03

Scan: 2Theta-Omega, 2.00 $-80.00^{\circ} @ 0.04^{\circ} / 2 \mathrm{~s}$

File: D30318E

\section{Phase/Qualification/Semi Quant}

Cerianite, CeO2, PDF 34-0394/Positive ID/ 60 wt\%

Sylvite, KCl, PDF 41-1476/Positive ID/<10 wt \%

Halite [Solid-Solution/Binary Salt, Na $\sim 0.9$ ], PDF 75-0305/Positive ID $/<5 \mathrm{wt} \%$

Bunsenite, NiO, PDF 47-1049/Positive ID/<10 wt\%

Magnesiochromite*, MgCr2O4, PDF 10-0351/Positive ID/ 15 wt $\%$

Eskolaite, Cr2O3, PDF 38-1479/Positive ID $/<5$ wt $\%$

\section{Notes}

[1] Sodium content in binary salt was approximate.

[2] Solid solution possible in the case of Magnesiochromite* (a spinel was definitely present; "Positive ID" refers to structure match).

[3] Two weak peaks could not be identified. These were ignored in the semi quant calculations. 


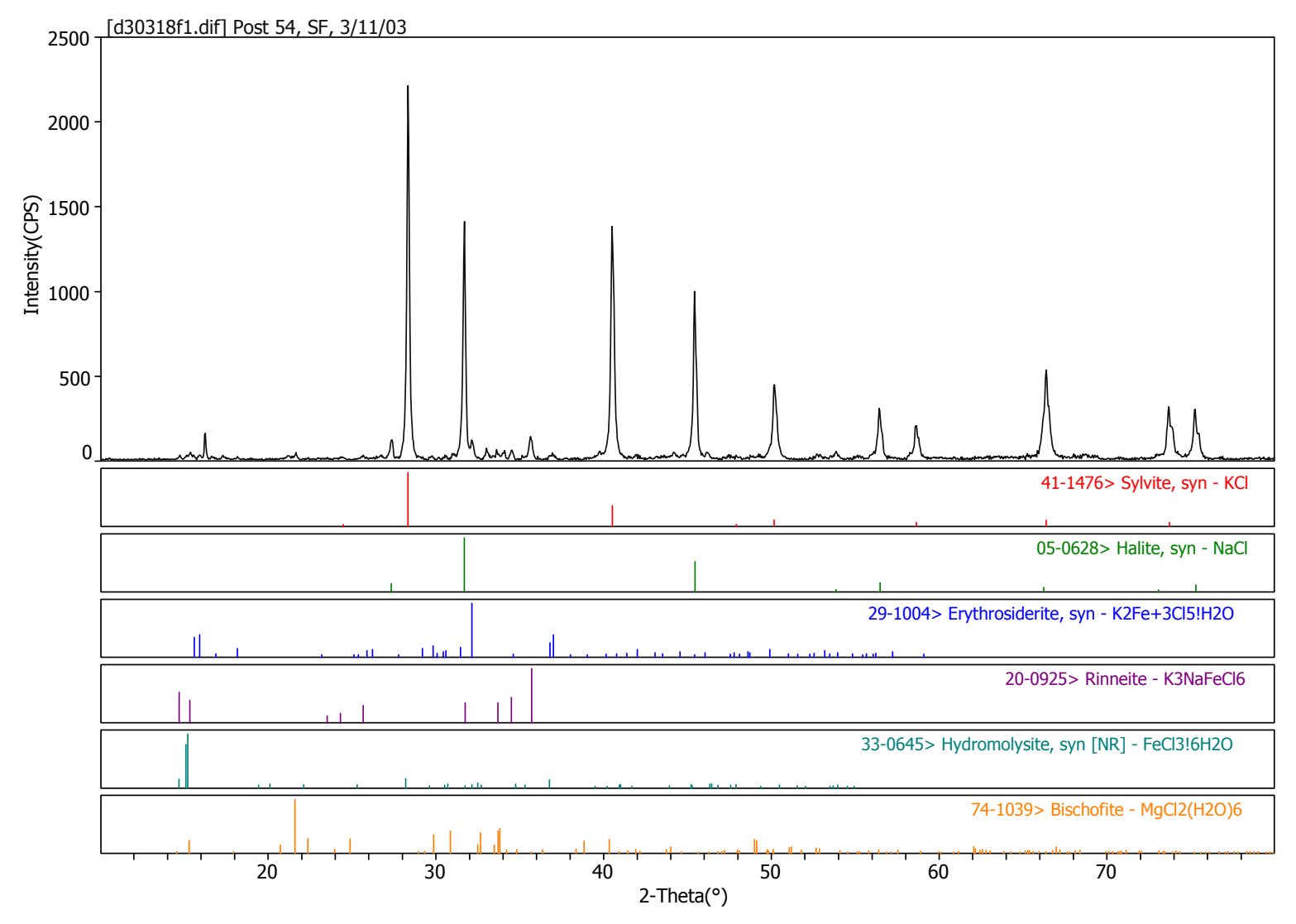

Figure B.6. Full-scale XRD Pattern for Cycle 54 Scrapings from Filter Element

Sample: Post 54, SF, 3/11/03

Scan: 2Theta-Omega, 2.00-80.00@0.04\% $/ 2 \mathrm{~s}$

File: D30318F

Comments: "SF" above $=$ Scrapings from Filter

\section{Phase/Qualification/Semi Quant}

Sylvite, KCl, PDF 41-1476/Positive ID/ 60 wt\%

Halite, $\mathrm{NaCl}$, PDF 05-0628/Positive ID/ 40 wt \%

Erythrosiderite, K2FeCl5 . H2O, PDF 29-1004/Tentative ID

Rinneite, $\mathrm{K} 3 \mathrm{NaFeCl6} / \mathrm{Tentative} \mathrm{ID}$

Hydromolisite, $\mathrm{FeCl} 3$. 6H2O, PDF 33-0645/Tentative ID

Bischofite, $\mathrm{MgCl} 2(\mathrm{H} 2 \mathrm{O}) 6$, PDF 74-1039/Tentative ID

\section{$\underline{\text { Notes }}$}

[1] Minor phases ignored in semi quant calculations.

[2] Several weak peaks could not be identified ("Residual Pattern") 


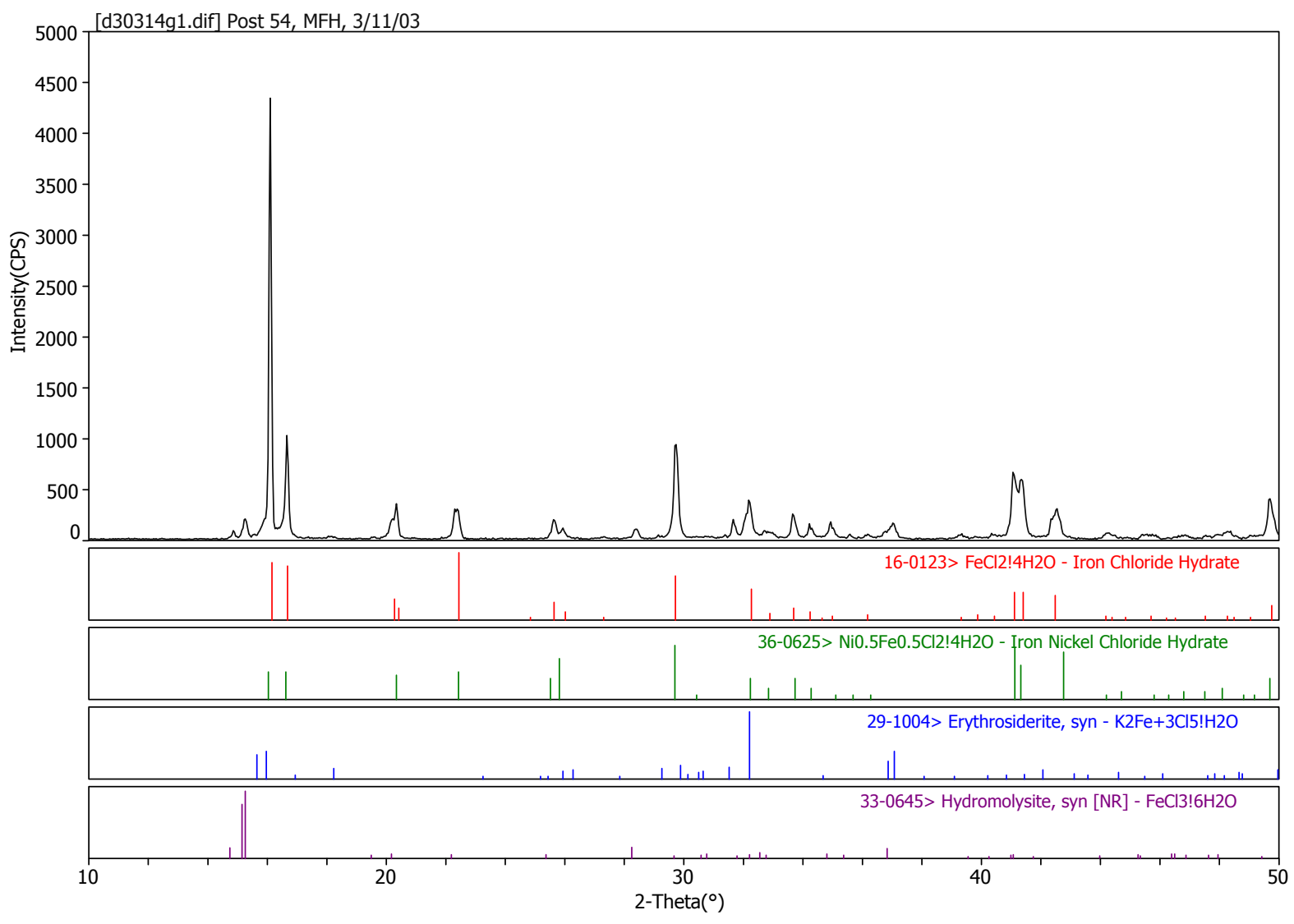

Figure B.7. Full-scale XRD Pattern for Cycle 54, Material from Filter Housing (Plus PDF 36-0625)

Sample: Post 54, MFH, 3/11/03

Scan: 2Theta-Omega, 2.00-80.00 $0.04^{\circ} / 2 \mathrm{~s}$

File: D30314G

Comments: "MFH" above = Material from Filter Housing

\section{Phase/Qualification/Semi Quant}

$\mathrm{FeCl} 2$. 4H2O, PDF 16-0123/Positive ID/ 85 wt\%

Erythrosiderite, $\mathrm{K} 2 \mathrm{FeCl} 5$. H2O, PDF 29-1004/Positive ID/ 10 wt $\%$

Hydromolisite, $\mathrm{FeCl} 3$. 6H2O, PDF 33-0645/Positive ID/ 5 wt\%

\section{$\underline{\text { Notes }}$}

[1] As shown, the major phase exhibited $<001>$ preferred orientation.

[2] Also, as indicated by the similarity to PDF 36-0625, a solid solution with $\mathrm{Cr}$ was possible.

[3] Solid solutions possible. 


\section{Appendix C}

\section{Furnace and Boat Temperature Profiles}

Thermocouple placement for Figures C.1 through C.4

The tips of thermocouples TC-100 and TC-105 were submerged in the simulant in the boat. TC-100 was placed 2 to 3 in. from the front of the boat.

TC-105 was placed in the center of the boat.

"Furnace" = furnace control thermocouple, which was located on the back wall of the furnace. 


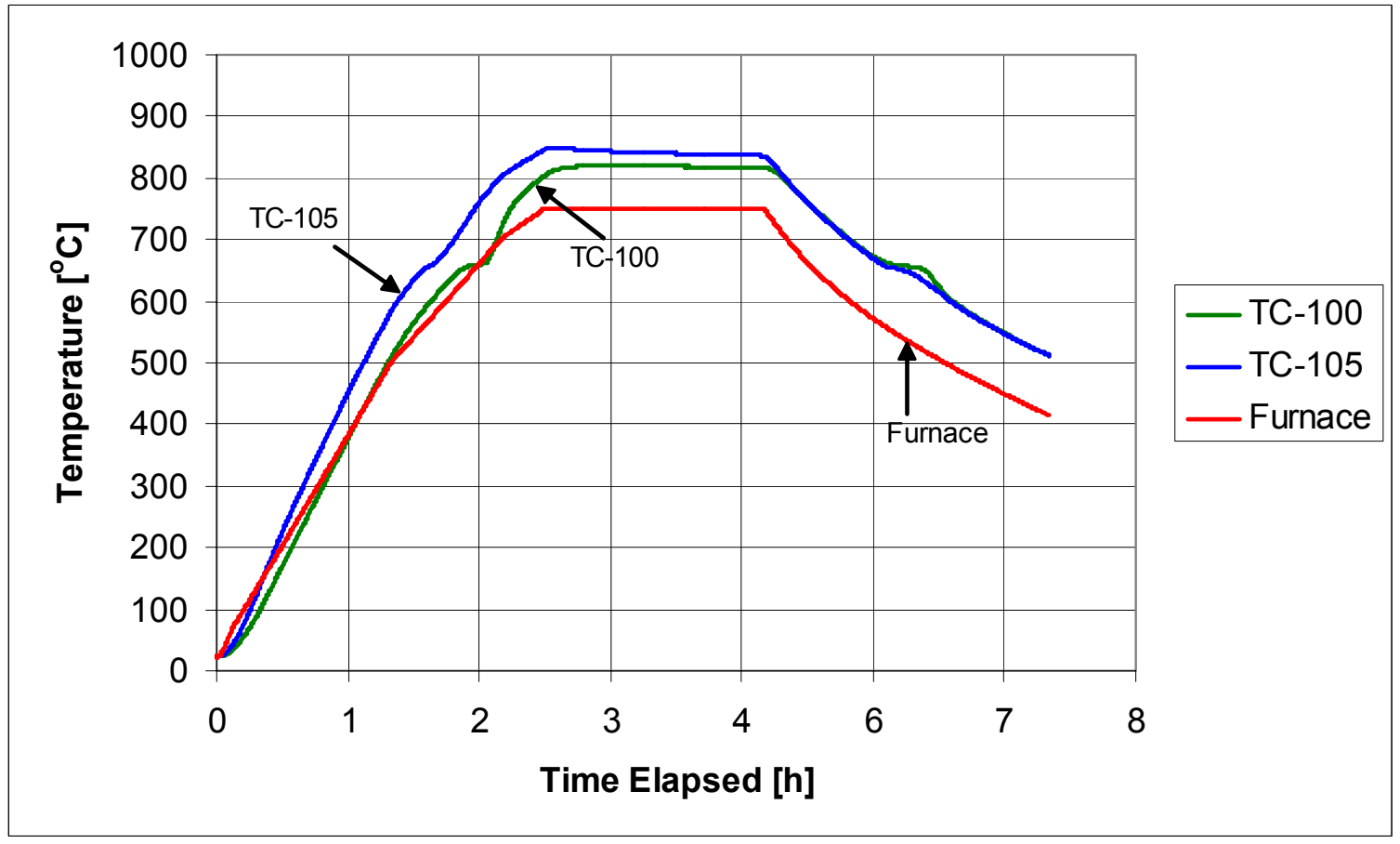

Figure C.1. Temperature Profile in Furnace and Boat During Cycle 51

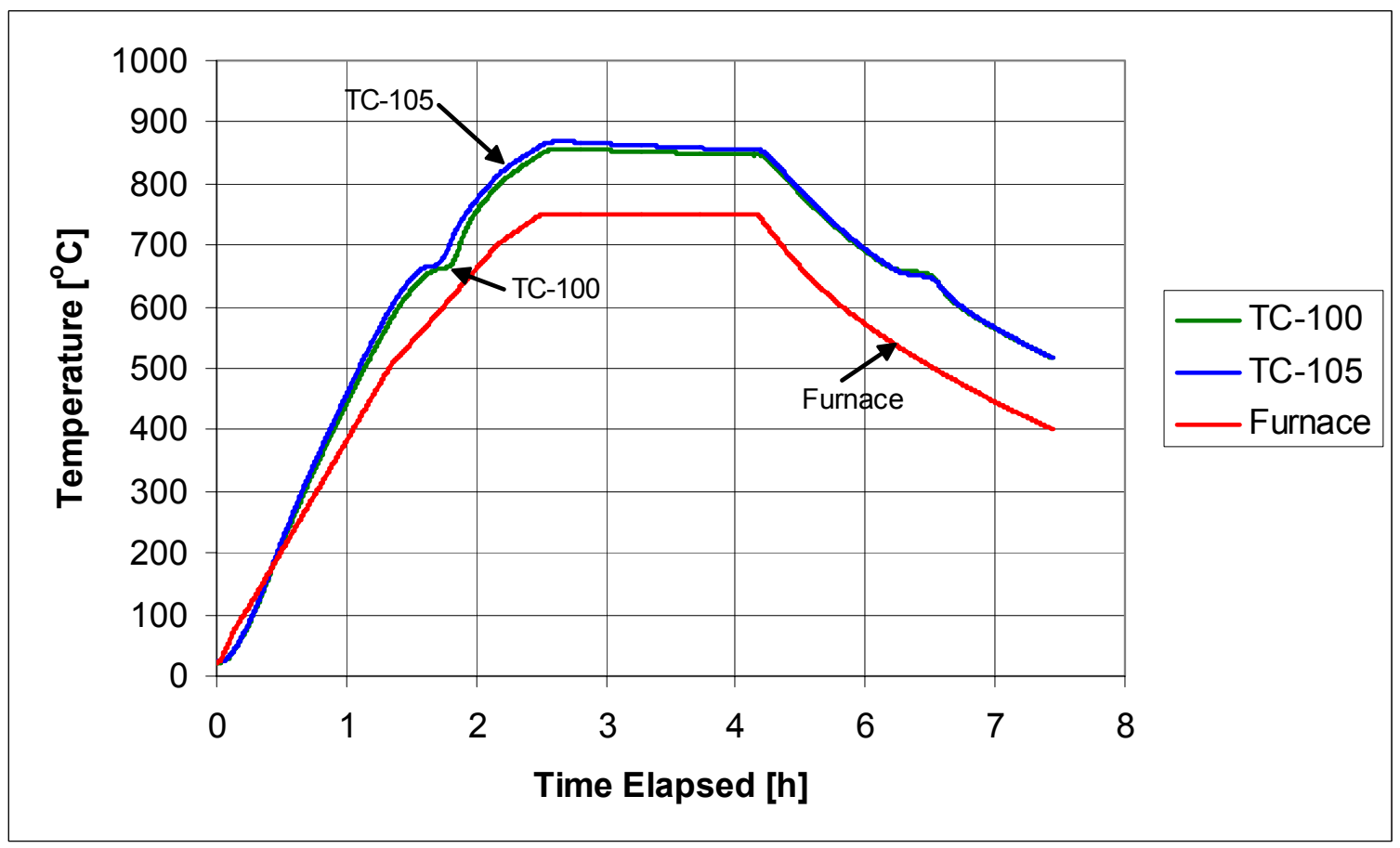

Figure C.2. Temperature Profile in Furnace and Boat During Cycle 52

C. 1 


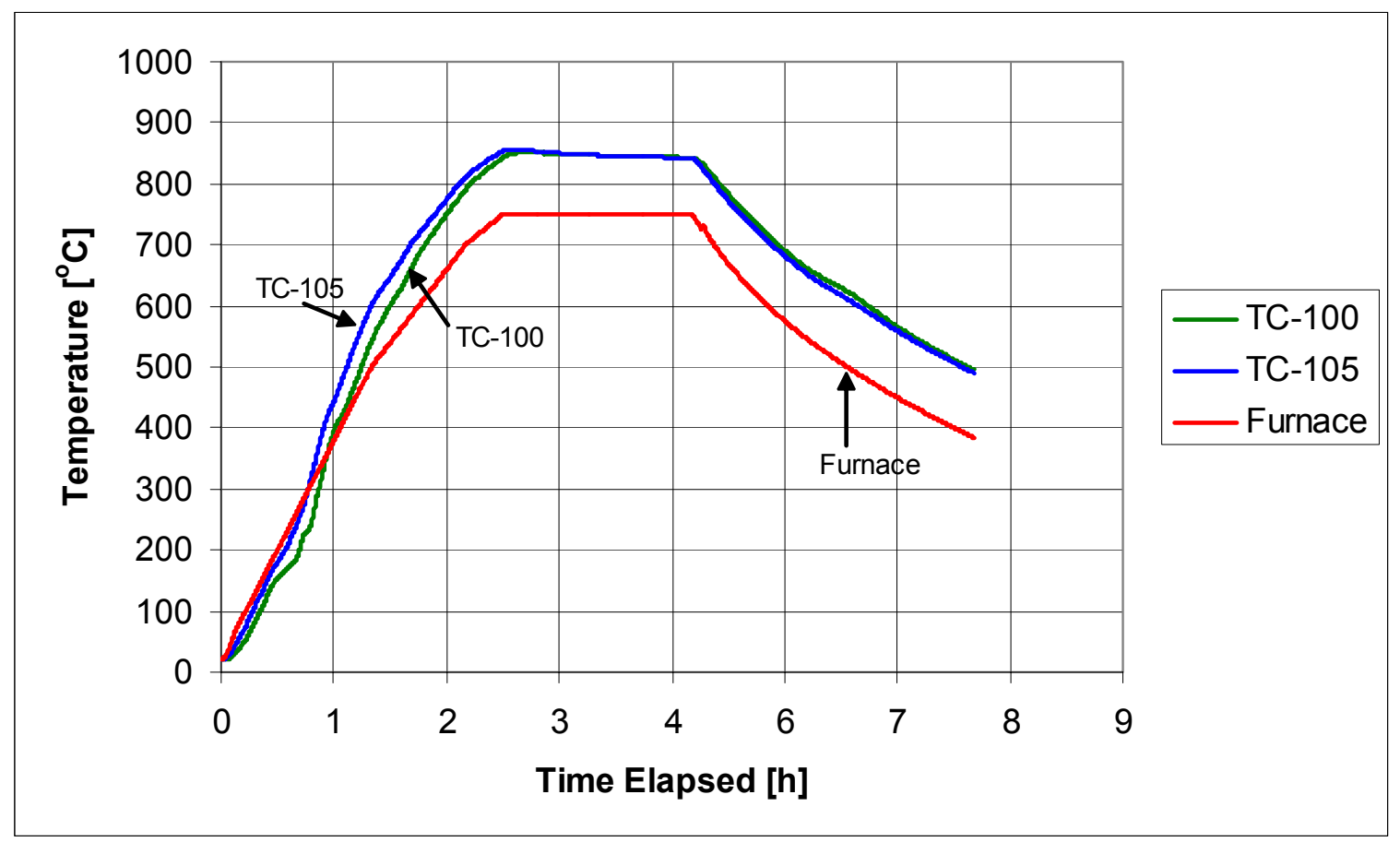

Figure C.3. Temperature Profile in Furnace and Boat During Cycle 53

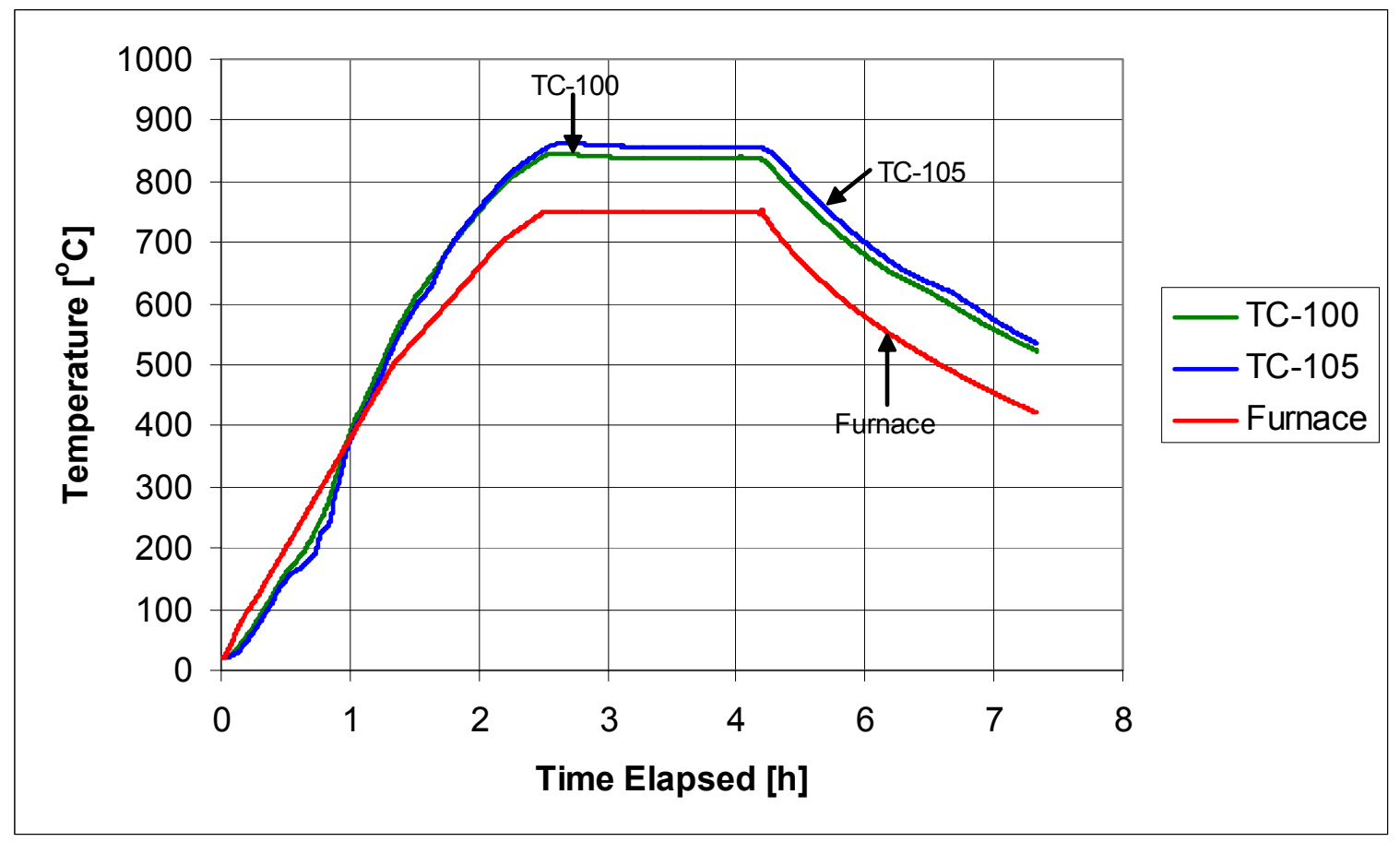

Figure C.4. Temperature Profile in Furnace and Boat During Cycle 54 